\title{
Child Poverty and Policy - \\ A Comparison of New Zealand and Scandinavia
}

By

Tor-Espen Stenerud

\begin{abstract}
A Thesis
Submitted to the Victoria University of Wellington in Fulfilment of the Requirements for the Degree of Master of Arts in Political Science
\end{abstract}

School of History, Philosophy, Political Science and International Relations

Victoria University of Wellington 2009 


\section{Norwegian abstract}

Denne oppgaven bruker de seneste tilgjengelige inntektsdata, fra år 2000, til å gjennomføre en sammenliknende analyse av fattigdom blant barn i New Zealand, Norge og Sverige.

Ved å sammenlikne forskjellige land med forskjellig utbredelse av fattigdom og forskjellig fattigdomspolitikk er målet å undersøke årsakene til barnefattigdom og viktigheten av fattigdomspolitikk for å redusere den, med utgangspunkt i et gitt teoretisk rammeverk og forståelse av hva fattigdom er og hvorfor det er vesentlig.

Mer spesifikt er formålet med oppgaven å undersøke i hvilken grad politiske forskjeller i form av (skatt og) trygdesystemer kan forklare forskjellene i fattigdomsnivå blant barn og unge, og i dette tilfelle forklare hvorfor barn i New Zealand er så mye mer utsatt for fattigdom enn barn i Norge og Sverige. Til dels blir dette gjort i en elimineringsprosess, hvor fattigdomsnivåer i ulike deler av samfunnet, inndelt etter demografiske, utdanningsmessige, etniske, og arbeidsforholdsmessige faktorer, sammenliknes før og etter skatter, trygder og støtteordninger er innkrevet og utbetalt. Til tross for at bildet som dannes her er komplekst, og at politiske forskjeller ikke kan forklare alle forskjellene, viser det tydelig at politiske variabler er avgjørende for å forklare forskjellene i utbredelse av fattigdom blant barn.

For å oppsummere funnene på en mer tilgjengelig måte setter oppgavens siste del sammen ulike funn fra tidligere kapitler ved å stille kontrafaktiske 'hva om?' spørsmål. Her beregnes det hva effekten av å ha samme grad av fattigdomsreduksjon som de ekvivalente gruppene i Skandinavia opplever ville vært i forskjellige deler av det New Zealandske samfunnet. I kapitlet testes også effekten av forskjeller i demografisk sammensetning og markedsinntekt (dvs. inntekten før statlige intervensjoner gjennom skatter og monetære støtteordninger). Også dette kapitelet understreker at sammenhengene er komplekse, men til tross for at mange variabler spiller en rolle er det hevet over tvil at politiske forskjeller er avgjørende for å forstå forskjeller i frekvens av fattige barn på tvers av landegrenser. Det er med andre ord rom for regjeringer å gjøre mer for å redusere fattigdom enn New Zealand gjorde i 2000. 


\section{English abstract}

This thesis provides a comparative analysis of poverty among children in New Zealand, Norway and Sweden using the most recent available income data from year 2000.

By comparing different countries with different levels of poverty, and differing policies it attempts to say something about the causes of child poverty and evaluate the importance of policy as a remedy. This is done within one theoretical framework and understanding of what poverty is and why it is important.

More specifically, the purpose is to explore to what extent policy in the form of benefits (and taxes) explain the differences in child poverty, in this case why children in New Zealand are so much more likely to be poor than those in Norway and Sweden. This is in part done by a process of elimination, where poverty levels before and after taxes and transfers are compared in various sectors of the population divided by demographic, ethnic, educational, employment status and other factors. Even though the picture formed by the findings is complex and far from straight forward, and policy differences cannot explain all the differences, policy variables are fundamental in explaining the differences in child poverty levels.

In order to summarize the findings in a more accessible way the last part of the thesis puts together findings from previous chapters by asking a counterfactual 'what if?' question, based on the statistics in chapter 4 and 5. It estimates what the impact would have been on child poverty levels in various groups in the New Zealand community if its policy had achieved the same rate of poverty reduction as the equivalent groups experience in Scandinavia. In the counterfactual chapter the importance of differences across the countries in demographic composition and market income (i.e. the income before government intervention through taxes and benefits) are also tested for. This way of presenting the findings further reinforces the image of complexity with few straightforward causal mechanisms. However, while the thesis shows that many variables play a role in explaining the variation in outcome across the countries, it leaves little room for doubting that much of this variation must be explained by government intervention. There is, in other words, scope for governments to reduce poverty more than the New Zealand policies did in year 2000. 


\section{Acknowledgments}

The creation of this thesis started in some way with my decision in 2005 to do my postgraduate degree in politics at Victoria University in Wellington, New Zealand. When I left New Zealand nearly 30 months after I first arrived in Wellington in January 2006 I had not regretted that decision a single day. I doubt that I could have found a more welcoming atmosphere anywhere else in the world. While there are too many kiwis to mention here that deserves credit for that, there are three groups in particular that I hope to get a chance to come back to visit some day: my flatmates, the friends that I made at "Vic" and all the great people at St Paul's Lutheran Church. Thank you for making sure that my stay was such a positive and memorable experience and for all the things it taught me about myself. Takk also to my mother, grandmother and sisters who came all the way from Norway to visit me.

As anyone who has written acknowledgements for a postgraduate thesis probably knows, space does not permit mention of all the people who probably deserve thanks for one's academic development. I apologize to everyone that I'm about to leave out. Thank you.

First among the people I cannot leave unmentioned are my parents who I owe everything, but here I just want to thank you for always taking the time to answer all of my questions.

Among the many friends I have had the pleasure to spend time with over the years, Torgeir Ådland deserves special mention for the way we have stimulated another's curiosity through discussions and projects since we started school together more than 18 years ago.

I've had many great teachers over the years, and I hope that I have paid for that by being a good student to teach. The teacher who, more than anyone else, has formed my perspective on political science is associate professor Michael Alvarez at the 
University in Bergen. Thanks for the many insights you have offered on political science (and whisky, but that is a different toast).

Thank you to the politics lecturers at Victoria for among other things teaching me about New Zealand politics, especially Professor Nigel Roberts, Professor Stephen Levine, Professor Elizabeth McLeay, Dr Kate McMillan, Dr David Capie and Dr John Leslie.

Several people also deserve mention for various kinds of assistance with my work on the thesis project. Andrej Ricnik-Bay saved me much work and frustration in the statistics computing phase by providing expert computer assistance.

In Wellington, my fellow MA students, particularly Greg Stephens, Helena Cook, Oliver Chan and Kelvin Bannan provided much fun, food, drinks and support, including proof-reading in the process. In the final phase of my writing, in Bergen, Torgeir Ådland spent some of his time arguing with me and proof reading. Arild Een also provided some useful advice.

Thanks to the Luxembourg Income Study micro database for providing harmonized data from Norway and Sweden. Any error in the interpretation and manipulation of the data is my responsibility.

Many thanks for the support and co-supervision to Professor Nigel Roberts. Finally and most importantly, thanks to my other co-supervisor Associate Professor Bob Stephens for introducing me to the public policy field, guiding me back on track many times, supplying data and providing tips and feedback based on thorough and patient proof reading. Without our enjoyable meetings and discussions the thesis would not have unfolded the way it did - and since all remaining errors are mine, it must be a good thing it did.

Finally, thanks to the examiners, Susan StJohn and Paul Callister for helpful remarks. 


\section{Table of Contents}

1. Introduction 1

1.1. Why is child poverty important, and why is studying it difficult? $\quad 1$

1.2. Why focus on New Zealand and Scandinavia? 3

1.3. Outline of the thesis 5

2. Child poverty 6

2.1. Defining child poverty 6

2.2. Effects of child poverty: intergenerational transfers 11

3. Factors that determine and correlate with market income $\quad 15$

$\begin{array}{ll}\text { 3.1. Cross-national explanations of poverty } & 16\end{array}$

3.2. Ethnicity and immigration 18

3.3. Family structure and age 26

3.4. Return to ethnicity; the effect on family structure, age and poverty $\quad 45$

3.5. Education 50

3.6. Employment and benefit status 56

3.7. Spouse resemblance 57

3.8. Interaction effects $\quad 61$

4. Policy 67

4.1. Market and disposable income, taxes and transfers 68

4.2. Tax and transfer policies in New Zealand and Scandinavia 73

4.3. Cross-national explanations of poverty reduction 75

4.4. The effect of government intervention on poverty in $\begin{array}{ll}\text { New Zealand and Scandinavia } & 78\end{array}$

4.5. Income redistribution and ethnicity 82

4.6. Government intervention and family structure 86

4.7. Government intervention and education attainment 99

4.8. Government intervention and income source 103

4.9 Interaction effects in disposable income poverty 107

5. Counterfactual analysis 111 
5.1. Overall household and child poverty level analysis 112

5.2. Household and child poverty level analysis - ethnicity 115

5.3. Household and child poverty level analysis $\begin{array}{ll}\text { demographics: age and family structure } & 119\end{array}$

5.4. Household and child poverty level analysis - income source 128

6. Answered and unanswered questions $\quad 131$

6.1. Policy developments in New Zealand since $2000 \quad 131$

$\begin{array}{ll}\text { 6.2. Answered questions } & 133\end{array}$

6.3. Unanswered questions 136

6.4. Conclusion 139

7. Appendix 141

7.1. The Revised Jensen Equivalence Scale $\quad 141$

7.2. Public sector social expenditure as a percentage of GDP 142

7.3. New Zealand source of income data and poverty;

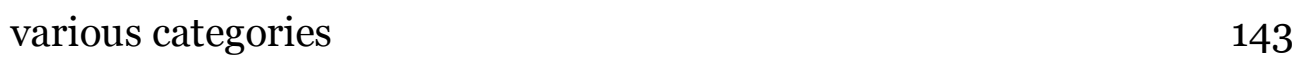

\begin{tabular}{ll} 
8. & Bibliography \\
\hline
\end{tabular} 


\section{List of Figures}

3.1 Population proportion with two foreign born parents in Norway, by background $\quad 21$

$\begin{array}{lll}3.2 & \text { Fertility rate by mothers' age } & 28\end{array}$

3.3A Poverty rate and poverty depth in New Zealand 37

3.3B Poverty rate and poverty depth in Norway 38

3.3C Poverty rate and poverty depth in Sweden 38

3.4 Upper secondary and tertiary educational attainment percentage by age group and gender in New Zealand, Norway and Sweden 52

4.1 Total tax revenue, 1955-2005 73

4.2 Public sector social expenditure as a percentage of GDP 74

6.1 Observed and counterfactual child poverty levels in New Zealand 


\section{List of Tables}

3.1 Proportion and number of foreign born population in Sweden in 2001 by age group $\quad 22$

3.2 New Zealand population by birthplace and ethnicity 2001

$\begin{array}{lll}3.3 & \text { Age Structure } & 27\end{array}$

3.4 A Market income household and child poverty in New Zealand by number of children

3.4 B Market income household and child poverty in Norway by number of children

3.4 C Market income household and child poverty in Sweden by number of children

3.5 A New Zealand market income poverty rate by family type

3.5 B Norwegian market income poverty rate by family type 35

3.5 C Swedish market income poverty rate by family type 35

3.5 D Comparing New Zealand with the average of Norway and Sweden 36

3.6 A Households' market income poverty rates by number of people over 60 in New Zealand 40

3.6 B Households' market income poverty rates by number of people over 60 in Norway 40

3.6 C Households' market income poverty rates by number of people over 60 in New Zealand 41

3.7 Market income poverty by head of household's age 42

3.8 A Norwegian market income poverty by marriage status of head of household

3.8 B Swedish market income poverty by marriage status of head of household

3.9 A Market income poverty by ethnic affiliation of household head in New Zealand $\quad 46$

3.9 B Market income poverty in Norway by immigrant status 46

3.9 C Market income poverty in Norway by immigrant status 47 3.10 A Household poverty, by age of household head, 
immigrant status, Norway

3.10 B Household poverty, by age of household head, immigrant status, Sweden

3.11 A Household and child poverty in Norway, by highest educated adult in household

3.11 B Household and child poverty in Sweden, by highest educated adult in household

3.12 A New Zealand market income poverty by benefit status 56

3.12 B Norwegian market income poverty by benefit status

3.12 C Swedish market income poverty by benefit status

3.13 OLS Regression of household divergence from median income by education and spouse resemblance, standardized coefficients

3.14 Market poverty in young parent and one-adult households

3.15 Market income in one-adult households with three or more children

3.16 Market income in one-adult, immigrant households

3.17 Market income in immigrant households with 3 or more children

4.1 Child and household poverty rates by market and disposable income in New Zealand and Scandinavia

4.2 A New Zealand child and household poverty by ethnicity

4.2 B Norwegian child and household poverty by ethnicity 84

4.2 C Swedish child and household poverty by ethnicity 85

4.3 A New Zealand household poverty by number of children $\quad 87$

4.3 B Norwegian household poverty by number of children $\quad 87$

4.3 C Swedish household poverty by number of children 88

4.4 A New Zealand household poverty by family type 90

4.4 B Norwegian household poverty by family type 91

4.4 C Swedish household poverty by family type 92

4.5 A New Zealand child poverty by family type 93

4.5 B Norwegian child poverty by family type 93

4.5 C Swedish child poverty by family type 94

4.6 A New Zealand poverty rates by household head age 94 
4.6 B Norwegian poverty rates by household head age

4.6 C Swedish poverty rates by household head age

4.7 A New Zealand poverty rates by people over 60

4.7 B Norwegian poverty rates by people over 60

4.7 C Swedish poverty rates by people over 60

4.8 A Norwegian poverty rates by head's or spouse's highest education attainment

4.8 B Swedish poverty rates by head's or spouse's highest education attainment

4.9 A New Zealand poverty rates by income source and employment status

4.9 B Norwegian poverty rates by income source and employment status

4.9 C Swedish poverty rates by income source and employment status 106

4.10 Poverty in young parent and one-adult households 108

4.11 Poverty in one-adult households with three or more children 108

4.12 Poverty in one-adult, immigrant households 109

4.13 Poverty in immigrant households with 3 or more children 109

5.1 New Zealand household and child poverty rates with Scandinavian rates of poverty reduction

5.2 Scandinavian household and child poverty rates with New Zealand market poverty rates

5.3 Counterfactual analysis of New Zealand child and household poverty by ethnicity

5.4 A Counterfactual analysis of New Zealand household poverty rates by number of children, based on Scandinavian poverty reduction rates 119

5.4 B Counterfactual analysis of Scandinavian household poverty rates by number of children, based on New Zealand market poverty rate $\quad 120$

5.5 A Counterfactual analysis of New Zealand household poverty rates by family type, based on Scandinavian poverty reduction rates

5.5 B Counterfactual analysis of Scandinavian household poverty rates by family types, based on New Zealand market poverty rate 
5.6 A Counterfactual analysis of New Zealand household poverty rates by age of household head, based on Scandinavian poverty reduction rates

5.6 B Counterfactual analysis of Scandinavian household poverty rates by household head age, based on New Zealand market poverty rate

5.7 A Counterfactual analysis of New Zealand household poverty rates by employment status, based on Scandinavian poverty reduction rates 129

5.7 B Counterfactual analysis of Scandinavian household poverty rates by employment status, based on New Zealand market poverty rates 130

$\begin{array}{lll}7.1 & \text { The Revised Jensen Equivalence Scale } & 141\end{array}$

7.2 Public Sector Social Expenditure as Percentage of GDP 142

7.3 New Zealand source of income data and poverty; various categories 143 


\title{
Child Poverty and Policy - A Comparison of New Zealand and Scandinavia
}

\author{
1. Introduction
}

\subsection{Why is child poverty important, and why is studying it difficult?}

An improved understanding of the causes of child poverty is crucial for a variety of reasons, many of which also explain the complexities involved in achieving this. New family patterns and less family stability present families with different risks and challenges than those that faced the 1960s family structure, which the original welfare regimes were designed to handle (DiPrete and McManus, 2000:124, EspingAndersen, 2003). A better understanding of the causes of childhood poverty is fundamental in welfare systems' adaptation to a changing reality, especially since one of the goals of public policy in modern welfare regimes is to ensure equal opportunities irrespective of family background (McLaughlin and Baker, 2007).

There is no question that the conditions under which children grow up, and poverty in particular, impacts on their later life (Ballantyne et al., 2003, BrooksGunn and Duncan, 1997), but the strength of this impact varies between countries (Beller and Hout, 2006, d' Addio, 2007:47). This suggests that differences in policy play a role, strengthening the need for governments to understand the long term consequences of policy decisions. In the US, costs associated with childhood poverty in the form of "lost economic productivity and earnings as adults, and also additional costs associated with higher crime and poorer health later in life" is conservatively estimated by Holzer et al. (2007:3) to be the equivalent of US $\$ 500$ billion a year, or nearly 4 per cent of gross domestic product (GDP). Further, according to Whiteford and Adema (2007:7), fighting child poverty does indeed rank high among the priorities of policy makers in many of Organisation for Economic Co-operation and Development (OECD) member countries.

Jenson(2004) suggests that a trend of changes in policy amounts to a change of paradigm: from an understanding where child welfare is the responsibility of parents, to one where governments can invest in children's future by alleviating 
poverty in families with children. However, the effect of policies aimed at reducing child poverty is far from straight forward. Often child poverty must be seen in the light of intergenerational transmission of poverty. In other words, one can assume that there is a causal relationship between intergenerational transmission of poverty and childhood poverty that work both ways. Increasingly, the policy response to child poverty is taking into account the duration of poverty. However, studying the intergenerational side of child poverty, and the measuring the duration of poverty presents a challenge because of the need for longitudinal data (Solon, 2002), which are scarce, especially outside of the US. 


\subsection{Why focus on New Zealand and Scandinavia?}

A good way of testing hypotheses in social science is to identify dependent and independent variables, and look for significant patterns in these. Variation can occur across individuals, time and (geographical) space. Changes in child poverty rates occur at a slower rate than many other variables, hence time alone is unlikely to provide enough variation to draw firm conclusions. As with many variables in social science, child poverty is often studied by looking at (variation in) probability or rates of poverty in different pools of individuals sharing certain characteristics, rather than simply different individuals.

This thesis will look at rates of child poverty across space, specifically comparing rates in New Zealand and Scandinavia, defined here as Norway and Sweden. The most recent available data for all three countries are from the years 2000-2001, and this will be the focus for this thesis. This comparative approach allows testing of hypotheses about how policies may affect child poverty rates, and this will receive particular attention. Studying the effect of policies is easier in a comparative (i.e. spatial) perspective, as policies - like their outcomes - change too slowly for change over time to give a good overview. Comparing New Zealand with Norway and Sweden gives a good range of similarities and differences (each of which are particularly interesting to the degree that they are associated with differences and similarities in outcomes, i.e. child poverty, respectively).

Since the 1970 s these three countries have each displayed distinct developments in the area of welfare (including family) policy: starting from a position where social policy achieved the outcome of somewhat similar degree of equality in childhood conditions in all three countries until about 1980, with lower rates of redistribution in New Zealand (which is retained to the present). In the late 1980 os and early 1990s reforms that Blaiklock, et al. (2002:1) describes as "the most sweeping in scope and scale in any industrialized democracy" reduced redistribution rates in New Zealand especially for the second poorest groups. This trend has possibly been reversed, or at least slowed down since 1999 (Starke, 2005). It is interesting to note that significant changes in the welfare system took place under both National (right of centre) and Labour (left of centre) governments.

Sweden had the most extensive state welfare system, but experienced extensive cutbacks in the early/mid 1990 os under Conservative governments, but 
nowhere near the dimensions seen in New Zealand. Despite having a less dominant Labour party than Sweden, Norway's welfare system has probably become more rather than less similar to Sweden over the last 30 years, at least when compared to developments in an international context. Economic growth has been stronger and more consistent in Norway than in the other two countries during this period, which has made the arguments for cutbacks less convincing and urgent.

In terms of child poverty rate outcomes the situation in New Zealand has become much worse than in the other two countries. Using a 60 per cent of median income as a poverty threshold, the disposable income child poverty rate grew by 4.8 percentage points in New Zealand, compared to 1.2 in Sweden and -0.3 in Norway between the 1980 s and 2000. Market income child poverty rates ${ }^{1}$ have grown by 9.8 , 6.0 and 3.0 points respectively. In 2000 the market income and disposable income child poverty rates in per cent were 28.7, 14.6 (New Zealand); 16.1, 3.6(Sweden); and 13.3, 4.4 (Norway) respectively, all according to Whiteford and Adema (2007:18). These differences are, more than anything else, what this thesis will primarily try to explain. The independent variable that will receive most focus is welfare policies, but obviously differences in policy can only explain a fraction of the differences, so the thesis will also review what other factors that can and should be taken into account. Policies are results of the political system, so it is necessary to look at this in order to understand differences in policy. Some of the input into the political system is societal variables such as the conditions in which children grow up, and in this way the topic forms a complete circle.

This thesis will primarily focus on the part of the circle that links policy and social conditions. Looking systematically at differences in policy, outcomes, and other factors that influence the poverty rates, enables the conclusion to discuss to what extent it is possible for governments to reduce child poverty. In other words, whether other variables in which the countries differ override policies, and that some countries due to certain conditions will have higher child poverty rates regardless of what governments do.

\footnotetext{
${ }^{1}$ I.e. the poverty rate before taxes and government transfers are taken into account.
} 


\subsection{Outline of the thesis}

Chapter two describes the child poverty situation in the three countries. It raises the importance and difficulties associated with seeing poverty in a dynamic way which acknowledges that long term poverty is more likely to have negative consequences than short spells. It also provides a discussion of what these consequences are, and other factors associated with child poverty.

Chapter three describes and discusses various factors that may impact on poverty rates and explain differences between countries. Much of this deals with issues around demographics and general economic conditions which either affect child poverty, or provide a natural context for describing differences in child poverty. The fourth chapter focuses specifically on differences in government policy in the three countries, the differences in policy. Each of these chapters includes a section on relevant theory and literature.

The concluding fifth chapter discusses to what extent policy and other variables explain the differences in poverty rates outlined in chapter two. This is done by counterfactual analysis of the result of swapping policy and demographic conditions across countries, such the effect on poverty rates of having the Swedish tax system in New Zealand, or making the ethnic composition of the Norwegian population similar to the one in New Zealand.

Chapter six provide a brief overview of the developments in New Zealand's poverty policies since 2000, and concludes by summarising the questions that the thesis has and has not answered. 


\section{Child poverty}

This chapter contains two sections. The first provides a definition of child poverty, and the second discusses how and why poverty can be transferred across generations. The sum of these two sections should make it clear that these two issues are strongly connected.

\subsection{Defining child poverty}

Several clarifications are needed in order to reach a sufficiently precise definition of child poverty. By convention in the child poverty literature, and in accordance with the UN Convention on the Rights of Children, a child is defined as an individual under the age of 18 (Ballantyne, et al., 2003:6). Naturally, this means that only a very marginal fraction of all children will have their own (one-person) household supported by their own income. Hence, in order to say anything about the standard of living for children based on income or consumption data, one must assume that households to some extent pool their economic resources. From that starting point one must decide whether individuals or households will be the unit of analysis. Creedy \& Sleeman (2004) provide a thorough discussion of the implication of this choice. This thesis uses data that are weighted by household when comparisons to households without children are useful. When available, equivalent data weighted by children are also provided. In analyses in which data is weighted by households the poverty rate reflects the fraction or, more commonly, the percentage of poor households out of the total number of households. When the data is weighted by children the poverty rate is the share of poor children out of the total number of children. In these cases households with more than one child is counted more than once. $^{2}$

It is common to assume that there exists some kind of economies of scale in household consumption that increase with the size of households, but there are several ways to take this factor into account. Some of these methods take into account the assumption that children consume less than adults. Equivalence scales

\footnotetext{
${ }^{2}$ Theoretically one could also use families as a unit of analysis, as it often, but not always overlaps with households. The data used in this thesis does not delve any deeper into this issue, and the thesis will employ households (as opposed to family) as unit of analysis. Where the word family is used (to avoid repetitive use of the word household), it refers to the household, with a few obvious exceptions.
} 
assign a value to each household type in proportion to the household's assumed needs, based on the number of members and sometimes the age of the members. Using this method, it is possible to compare families of varying size. However, the construction of the scale is a result of more or less arbitrary decisions made by the researcher, and several equivalence scales has been in use: a square root scale, an "Oxford scale"/"old-OECD scale" ( 1 to the first member, subsequently .7 per additional adult and .5 to each additional child), OECD-modified scale ( 1 to the first member, subsequently .5 per additional adult and .3 to each additional child), in addition to scales adapted to local conditions (Whiteford and Adema, 2007:12). Through the equivalence scale it is also possible to take into account the age of the child or children and other family members, and many other factors, such as local price variations. This thesis will use the square root scale for data from Norway and Sweden, and the Revised Jensen Scale for New Zealand data (see appendix 7.1 for a discussion), because it unfortunately is impractical to change the use of the Revised Jensen Scale in the dataset used for New Zealand.

Once families with children have been defined and made comparable, it still remains to decide which of these are poor. Perry (2004:22) defines poverty as "exclusion from the minimum acceptable way of life in one's own society because of inadequate [economic] resources" (italics in original removed). While the view may still be contested in some political circles, poverty in the developed world is now widely understood in relative terms by researchers. This means that who is poor and who is not depends not only on absolute or subsistence living standards, but also what way of life, or living standard, is expected in the given country. While the focus on living standards implies that a range of indicators that measure material quality of life (or living standard) is relevant for measuring poverty, most studies emphasise income as a practical and broad measure. A direct measure requires a measure of low well-being per se is usually deemed impractical (especially when comparing situations across countries), and income is used as an indirect definition regarding the (in-) ability to pursue well-being (Mogstad et al., 2007:116). Income is also a measure that assumes some degree of choice in terms of choosing what goods to consume.

Poverty research deals with distribution of income or inequality on the lower end of the scale, and obviously this can be measured in many ways. Studies that deal with inequality more broadly, for example, often use the GINI-coefficient as 
a measure of inequality. However, in poverty research, as a simpler measure, it is common to draw a specified threshold and measure the frequency with which individuals or households fall below this line, the so-called headcount ratio (Perry, 2004: 33). This follows from the definition of poverty as a measure of inequality on the lower end of the scale. 50 per cent and 60 per cent of the median income are two common thresholds. Some studies use other, fixed or absolute poverty lines, often defined by governments. Throughout this thesis 60 per cent of the median disposable income will be used as the poverty line. Although, "[a]dopting a definition of 'low income' [or poverty threshold] inevitably involves a degree of arbitrariness" (Krishnan et al., 2002:124), they acknowledge that Stephens et al. (1995:11-12) provides a focus group study suggesting that in 1991 in New Zealand the minimum adequate household expenditure was very close to 60 per cent of the median disposable income. The same threshold is most commonly used in Europe. Using the median means that poverty statistics (both the threshold and the number of households falling below it) is unaffected by income changes among those above the median income, which reflects that the focus in poverty research is on the inequality between the poorest and the overall population and not on overall inequality. The poverty threshold approach requires a way or method of constructing a threshold that is valid across countries. This means that the NZ ELSI (New Zealand Economic Living Standard Index) (Krishnan, et al., 2002), while an interesting contrast to the income based studies, cannot be used in a comparative study like this. Perry (2002) analyses the difference between studies of poverty using income and direct outcomes as measures of poverty, and the mismatch between the two types of studies in a New Zealand context. The strength of outcome based studies are that they take into account other factors than income that are known to be relevant to achieve a certain standard of living, such as "cost of accommodation, debt repayments, ability to draw on assets when needs cannot be met from current income" (Krishnan, et al., 2002:8), etc. This strength means, however, that such studies almost by definition are specified to one particular context (i.e. country) and comparable data are not available across countries.

According to Mogstad et al.(2007:115-16) the standard practice in most OECD countries is to apply a national poverty line, even though theoretically "this approach requires identical prices of goods and services as well as uniform norms and consumption habits across regions [, otherwise] a joint country-specific poverty 
line might be biased.” They go on to construct regional poverty lines in Norway, and estimate the impact on poverty measures when these are used, rather than national thresholds. Their findings are interesting as an illustration of the sensitivity of the measuring problem (i.e. the assumption that prices of goods and services are identical throughout the area for which the poverty line is constructed) involved in using national poverty lines.

On the basis that housing costs is the main expenditure for households with low incomes, they focus specifically on differences in house prices. Dividing Norway's 435 municipalities3 into 21 groups according to (seven) regions and average cost per square meter of living area (three categories: top 25 per cent, bottom 25 per cent and middle), they estimate the poverty threshold in each of these. In doing so they avoid "comparing the income of individuals from municipalities with high housing prices with that of individuals from municipalities with relatively low housing prices" (Mogstad, et al., 2007:115). The poverty line 4 varies from NOK 73 700 in the eight municipalities with low housing costs in Eastern Norway, to NOK 93 800 in the two municipalities in the Oslo area with high housing prices. This group was something of an outlier, though, as the group with the second highest poverty line were the 3 high cost municipalities in Northern Norway (NOK 86 100).

They find that the overall poverty rate is only marginally affected by implementing regional poverty lines, increasing from 3.2 to 3.3 per cent. However, the characteristics of the poor changes substantially, in particular regarding urban or rural living areas: the poverty rate in urban areas increase from 3.2 to 3.5 per cent, while the rate in rural municipalities decrease by nearly a quarter from 2.9 to 2.2 per cent when using the region-specific rather than national poverty line (Mogstad, et al., 2007:120). They also find that characteristics known to increase risk of poverty such as young singles, or non-western immigrants have even higher poverty risks when region specific thresholds are used. In conclusion they write that it is "important to introduce poverty thresholds that account for the heterogeneity in prices and minimum needs within a country." (Mogstad, et al., 2007:121). However, this is easier said than done. First of all it requires such a large number of observations that register or census data are probably the only feasible solution; survey data will

\footnotetext{
${ }^{3}$ Which themselves are highly heterogeneous: varying from 200 inhabitants to 548000 and from $9 \mathrm{~km}^{2}$ to 9000 $\mathrm{km}^{2}$.

${ }^{4}$ The study employs the "Oxford Scale" equivalence scale, and the $50 \%$ of median market income poverty line. It uses data from 2001.
} 
probably never be sufficient. Even where sufficient data exist, they are frequently difficult to access for privacy concerns. Mogstad et al. (2007) has convincingly demonstrated the superiority of region-specific thresholds, and the need for them, but it seems likely that the shortcut through country-level will still dominate at least for some time. The sensitivity of relative poverty rates in urban and rural areas means that studies of the relationship between this variable and poverty probably requires region specific poverty lines. For other relationships it's worth noting that according to Mogstad, et al. (2007) the explanations of tend to be understated and not overstated when the less than perfect method of national poverty lines are used.

The headcount ratio method does not show, however, how much below the poverty line those that are poor are. This can be expressed through the so-called poverty depth, i.e. how much the income must be increased to bring individuals above various poverty thresholds. A simple measure of poverty depth called is known as the poverty gap. This can be calculated in several different ways, in this thesis the gap will be defined as the average size of the gap between actual income and the poverty line among the households that falls below the threshold. Poverty gap and poverty depth will be used interchangeably in the remainder of this thesis.

All the methodological decisions outlined in this section have important repercussions, both analytically and politically: the definition of the poverty threshold is obviously important for the findings, but differences in the household equivalence scales, whether to include in-kind benefits and definitions of households can also lead to very different findings.

The poverty incidence given a specific threshold is only comparable if other factors such as equivalence scales are also comparable. To the extent that poverty research are taken into account by the public and policy makers, the methodological choices also affect outcomes: a low poverty threshold portrays may create an image of poverty as a problem that is not very widespread; using poverty rates without focus on poverty depth may give a focus on individuals just below the poverty line rather than those in most extreme poverty.

However, those decisions must be made on a more or less arbitrary basis; it is hard to find grounds on which one solution can be said to be better than any other for all purposes. To highlight this it is often worthwhile to test the conclusions' sensitivity to changes in these methodological decisions. 


\subsection{Effects of child poverty: intergenerational transfers}

The bulk of the data used in this thesis is static rather than dynamic in the sense that data are collected at only one point in time. This has two main advantages: firstly that data is collected only once saves resources in the data collection process, in part because it makes it easier to guarantee respondents full anonymity. Secondly, it makes it easier to interpret, present and read the findings. These two factors allow the inclusion of a larger number of other variables, and leaves space for an analysis of the relation with policy. The "snapshot" poverty data presented here thus cannot say anything about how much time individuals have spent in poverty. In many cases it may have been transient, a one-time slump. In more serious cases it could be intermittent or even become chronic. Importantly, it could also be permanent in the sense of lasting across generation, with little hope of a way out. While static and dynamic measures of poverty could be seen as two different things, all prevailing poverty will show up in static measures of poverty, and if there was no poverty in a static measure, that would also mean no permanent poverty.

Similarly, it would certainly be interesting to know how successful governments' efforts to prevent poverty to be inherited across generations have been. However, it is arguably even more important to evaluate governments' effort to reduce poverty among children growing up today, even if the data does not differentiate between transient and chronic poverty, even though we know that chronic poverty is more damaging for an individual's long term opportunities.

One way of describing the long term effects on an individual of growing up in poverty is to look at intergenerational transmission of poverty and other advantages and disadvantages. This assumes that the conditions under which children grow up can be described by looking at the parents, and the long term effects of these by looking at the welfare that the child experiences as an (young) adult. There is a growing literature on the topic, but although it is an empirical question to what degree poverty and other factors are transferred across generations, the process creating this effect is still not thoroughly understood, for at least two reasons: first, this way of observing the consequences of childhood poverty requires data that describe individuals over a very long period of time (Solon, 1992). Such data are scarce for two reasons: because only relatively recently did it become 
possible to analyse the amount of data required for such a study, and because such longitudinal studies of individuals must be tailored for its purpose. "Snapshot-data" collected for other purposes cannot be used because they, for privacy reasons, usually ensure that individuals cannot be identified, and thus cannot follow individuals or households through time. Second, even to the extent that data can be found, accounting for what mechanisms causes poverty to persist across generations is by no means straight forward, as there are many potential explanations, ranging from genetics and personality traits to education, health and social networks (d' Addio, 2007).

d'Addio (2007) reviews the international literature on the topic. She points out that sociologists typically focus on mobility across class and occupations, while economists deal with income mobility (2007:12). The sociology approach focuses on variables such as parental income and education, home and social environment where the children are raised, and where beliefs, attitudes and values are shaped. These factors interact with cognitive and non-cognitive abilities to affect life chances measured in outcomes such as early pregnancy, criminal activity, violence and drug use (d' Addio, 2007:26). Jencks \& Tach (2005) discusses whether equal opportunity would actually result in more mobility, and concludes that there are many reasons why one could expect that even in a society where everyone experiences equal opportunities, many traits would still be passed on across generations.

The economics literature dealing with the same issue focus on whether childhood or parent variables (such as parents' income) predict future income of children, and through which channels such effects work.

Maloney (2004) address the link between parental income and outcomes for young adults based on data from New Zealand, specifically the Christchurch Health and Development Study (CHDS), which follows a birth cohort of 1.200 individuals born in Canterbury/Christchurch in 1977 up to age 21. One major weakness of the study is that it samples only one geographical area of New Zealand at one point it time, so it is not necessarily representative beyond that. Another weakness is that in terms of income, age 21 is too early to say much about income, as many individuals who will later experience relatively high lifetime income will still be students. Several observations of parental income provide a better picture of "permanent" income of the family and also the opportunity estimate income effects 
at various stages in the children's development. The dependent variables used are economic inactivity, early parenthood, alcohol or drug dependence or abuse, criminal activity/arrest or conviction, or no educational qualifications (Maloney, 2004:6062). Out of these, the variable with the strongest correlation with parental income during childhood is the absence of a formal educational qualification. However, when certain variables (gender, ethnicity, parents' education and socio-economic status, mother's age at birth of child, proportion of years lived in a single-parent family, and the number of siblings in family at age 15 , in addition to two intelligence or problem solving tests seen as mediating variables) are controlled for, the effect of family income on lack of qualifications and economic inactivity and early parenthood were found to be similar. The study finds no effect of parental income on alcohol/drug abuse/dependence and only weak effects on criminal activity, which are further weakened by inclusion of the control variables, and disappears entirely when the mediating variable are included.

The study uses various measures of the family/parental income, and finds that the effect of income in childhood is consistently stronger for lower incomes/ poverty than high incomes. In other words, among the children who experienced poverty it often contributed to detrimental outcomes, while experiencing very high or medium incomes made little difference. This is a strong justification for focusing on poverty specifically, rather than inequality as such.

The study suggests that family income while the children were in their latter stage of child development (age 11-14) made most difference, except on the absence of qualification variable where the early stage (age 1-5) made most difference. On none of the variables was the middle stage most important (Maloney, 2004:77-79).

Despite the challenges related to measuring and comparing intergenerational mobility, research findings in the area hold important implications for the study of child poverty: it demonstrates to what degree child poverty has long term effects, and may also tell us about through what mechanisms poverty can be harmful and thus what kind of child poverty is most damaging (e.g. at what age are children most vulnerable to poverty, and what other factors make poverty particularly harmful). The wide range of approaches to measuring intergenerational mobility is appropriate given the diversity of effects that child poverty may have. The 
public's and policymakers' understanding of such effects should also be expected to affect family and redistributive policies. 


\section{Factors that determine, and correlate with market income}

Section 1.2 used the study by Whiteford and Adema (2007) to describe the differences in child poverty rates in New Zealand, Norway and Sweden. This chapter will explore how much of these differences existed "before" direct government interventions, i.e. market income. The approach does to some degree assume this order, i.e. that market income precedes government intervention, and in other words that employment decisions (and market income) are not themselves affected by government interventions. This market poverty rate does not describe "real" poverty in itself, but indicates to what extent the (levels of) wages and employment that the market offers is an opportunity to avoid poverty. The conceptual distinction between market income and disposable income is in other words central in this thesis. The policies that drives the difference will be interchangeably be referred to as (government) income redistribution, government intervention and income transfers.

The income data will mostly rely on the 2000 Household Economic Survey (HES) for New Zealand data, and the 2000 Luxembourg Income Study (LIS) for Swedish and Norwegian data. For New Zealand poverty information has been obtained from Robert Stephens, New Zealand Poverty Measurement Project (NZPMP), and here the information was derived from the data from the 2001 edition of the Household Economic Survey (HES). This is a sample survey conducted every three years on "the incomes and expenditure patterns of private households throughout New Zealand" (Statistics New Zealand, 2001). Stephens, Waldegrave and Frater (1995) provide the NZPMP methodology, Waldegrave , Stephens and King (2003) provide an analysis of the 2000/2001 data.

It is necessary to separate market income and disposable income/policy effects, because before one can say anything about the effectiveness of government intervention one must know the size of the problem the intervention is trying to solve. After a review of comparative literature that analyses international differences in market income poverty, the effect of various factors that describe households in the three countries at hand will be explored. This could be done in any order, but to make the interaction effects of these variables more readily understood they will be 
organized according to how frequently they change; hence starting with ethnicity, followed by family structure and age, education, employment, the effect of spouse resemblance, and lastly a discussion of how these factors may interact. The findings in this chapter will be used in chapter 5 to summarize the relative importance of the factors explored in this chapter relative to the policy lever variables that will be discussed in chapter 4 .

\subsection{Cross-national explanations of poverty}

Moller, Huber, Stephens, Bradley, \& Nielsen (2003) applies data from 14 advanced capitalist countries 5 from the period 1970 to 1997 in order to evaluate several variables' importance in explaining variation in pre-tax/transfer poverty, and poverty reduction through tax and transfers (see section 4.1). Their dependent variable is pre-tax/transfer poverty rates (in the overall population, the study is not a specific study on child poverty) and the effect of tax and transfers on poverty rates. They test a wide range of independent variables: economic development (PPP6 adjusted GDP per capita, agricultural employment, percent of the population below 15 years old, secondary school enrolment, and vocational training), inverted-U relationship7 between modernisation and equality (industrial employment, LDC8imports, capital market openness, direct foreign investments overseas, immigration, unemployment rates, female labour force participation, and single mother families), labour market institutions (union membership and coordinated wage bargaining), politics (left cabinet, Christian democratic cabinet, women's organizational strength and constitutional veto points), and policies (welfare generosity, share of social transfers that are: means tested; child and family allowances; maternity allowances; and unemployment replacement rates). They find that employment rates, 9 and wage coordination are the strongest and most significant positive predictors (the only variables significant at a .oo1 level when

\footnotetext{
${ }^{5}$ Using data from among others, the LIS, which includes Norway and Sweden, but unfortunately not New Zealand.

${ }^{6}$ Purchase power parity, a measure that corrects for differences in purchasing power when comparing the value of an amount of money across time, space and currency.

${ }^{7}$ Moller et al.(2003)'s term for the theory that suggests that equality is lowest at very high or very low levels of modernisation, and vice versa. The term refers to the shape of a function for equality where modernisation is the independent variable on the $\mathrm{X}$-axis.

${ }^{8}$ Least Developed Countries; http://www.un.org/special-rep/ohrlls/ldc/list.htm (accessed 28/5-08) provide a definition.

${ }^{9}$ The unemployment variable is not complemented with a variable for economic growth, which could potentially be an important driver behind this finding.
} 
variables from all categories above are included) of low pre tax/transfer poverty rates. ${ }^{10}$ In their model they achieved a $\mathrm{R}^{2}$ of $.67 .{ }^{11}$ This indicates that the labour market is where one should look for explanations for cross-national differences in overall market income poverty rates (without a specific focus on child poverty), i.e. the size of the problem poverty policies attempts to remedy.

Brady (2004) provides a study dealing with similar issues, focusing on the differences and similarities of child poverty, elderly poverty and overall poverty. The study incorporates data from 18 rich, western, democracies between 1969 and 2000 $(\mathrm{N}=91)$. According to the study child poverty is significantly and negatively correlated with social security transfers, public health spending, female labour force participation (all of which also affects overall and elderly poverty), manufacturing employment and economic growth (which affect overall poverty, but not elderly poverty). It is also positively correlated with children in single-mother families (i.e. this is associated with higher child poverty rates), but this variable does not affect overall poverty or elderly poverty. Child poverty is not affected by unemployment (which curiously enough is negatively correlated with elderly poverty), or elderly population (associated with higher overall poverty).

\footnotetext{
${ }^{10}$ The study does not, however, say anything about for how long individuals remain poor.

${ }^{11}$ This means, somewhat simplistically put, that the model could account for $67 \%$ of the variation in the dataset.
} 


\subsection{Ethnicity and immigration}

Borjas and Sueyoshi (1997) demonstrate that in the US ethnicity (and the dominating ethnicity of neighbourhoods) affects not only the incidence and duration of what they call "welfare spells", which presumably is strongly correlated with poverty, but also the probability of poverty being "inherited" across generations. They argue that both the traditional economic approach to explaining intergenerational transfer of poverty through parental investments in the human capital stock of their children (e.g. Becker, 1991), and the sociology literature approach to the same phenomenon which stresses the importance of neighbourhood or environmental variables (e.g. Coleman, 1988, Wilson, 1987) are necessary to understand how ethnicity affects cross-generational poverty. The hypothesis put forward in Borjas and Sueyoshi (1997:2) is that "ethnicity matters because it influences the "quality" of the environment in which human capital decisions are made." They do, in other words, presume that parents' wish to invest in their children's future (through education and other forms of well-being) exist across ethnic boundaries. However, ethnicity is correlated with sociological environment which affects the payoff from such investments, and thus the incentive to spend on this 'investment'. Their analysis of the US' National Longitudinal Survey of Youth confirms their hypothesis. It thus seems likely that ethnicity's impact on poverty is a factor that it is worth including also in this study. Given the static nature of the data used in this study, the focus is limited to how ethnicity determines frequency of poverty and related factors, the data used here does not permit analysis of how ethnicity affects cross-generational transfer of poverty.

Ethnicity is a factor that, while frequently a strong predictor of income and life chances, is too unique to each country to be run in large- $\mathrm{N}$ cross country study like those referred to in the previous chapter. A small-N study like this, on the other hand, does allow the inclusion of this variable, even though data availability requires that ethnicity and migration are to some extent used as proxies to for another, with all the problems that entails. To compare the ethnicity factor across countries is still complicated, and requires some simplifications that are partially at odds with conclusions reached by studies that focus specifically on ethnicity in one country, but should still be acceptable in a study on child poverty in multiple countries. It is beyond the scope of this thesis to look at why ethnicity seems to 
determine social outcomes. It will, however, look at to what extent ethnicity and immigrant status affects income directly and works through other variables.

When comparing the three countries it is striking how the issue of ethnicity is referred to as an issue of immigration in Norway and Sweden, where the non-immigrant population is ethnically highly homogenous compared to New Zealand. It is in fact hard to imagine being asked about one's ethnicity in Norway: the question would nearly always be one about Sami affiliation or immigrant background or citizenship/residence, While the New Zealand census has items on ethnic affiliation, Swedish and Norwegian studies tend to focus on immigrant status, which reflects the smaller size, and political invisibility of the indigenous ethnic minority group in Norway and Sweden, the Sami people. According to Statistics Norway,

"[n]o one knows exactly how many Sami there are today [...]There is no precise definition of who the Sami are, and Norway, Sweden, Finland and Russia all have varying criteria. The criteria that need to be met in order to vote in the Sameting elections in Norway are the most natural definition to use in Norway.

- The person must have Sami as their home language, or at least one of their parents, grandparents or great-grandparents must have or have had Sami as their home language

- $\quad$ The person regards himself to be Sami.

Because there is no overall registration of the Sami population, it is difficult to generate statistics on the Sami as a group. The statistics [...] based on the geographic range for the Sami Development Fund [estimates numbers of Sami people to:]

Norway: 40000

Sweden: 20000

Total: $\quad 70$ ooo." (Statistics Norway, 2007)

A Norwegian report from the Ministry of Health acknowledges that "many of the health and living condition surveys conducted has not taken sufficient account of ethnic background and Sami living conditions particularly [...] There are major differences in level of education between the [ethnic] groups" (Helsedepartementet, 2006:27, author's translation). While the differences in education level suggest that (Sami) ethnicity would have been an interesting variable, the lack of data means that a focus on poverty rates in the Sami population falls 
outside the scope of this thesis, and it will thus follow the convention of focusing on immigrant status (which partly is a proxy for ethnicity, and partly is interesting in its own right) in Scandinavia, and ethnicity in New Zealand. Due to the use of snapshotdata, this thesis will also disregard the increasing tendency for migration to be nonpermanent.

Even though ethnic differences are generally referred to as a matter of immigration in Scandinavia, New Zealand has to a much larger extent had a strategy behind its migration policy, and has for instance used skills screening of 'wanted skills' more actively than in Scandinavia. Such differences in migration policy do of course affect the welfare of immigrants including child poverty levels. Part of the reason why ethnicity is particularly interesting as a predictor of poverty and the reason for dealing with it first is that, as opposed to many other predictors, it does not change during most people's lifespan, and most people are not faced with making conscious decisions about their ethnicity. However, it also affects many of the other variables. Since it is unchangeable the direction of causality is clear; the challenge is to establish the degree to which ethnicity works through other variables (i.e. it is clear that given a correlation ethnicity affects e.g. education, not reverse, the question is to what degree ethnicity affects poverty through e.g. education). This section will look at the correlation of ethnicity and poverty, while the extent to which the effect works through other variables will be covered in later subchapters.

Neither ethnicity nor immigrant status should be reduced to dichotomous variables in poverty research. In New Zealand the effect of not being a Pākehā/ European New Zealander varies too much to give a single, meaningful picture: from Māori, to Pacific Islander to Australian or Asian immigrants. Similarly there is a vast difference between immigrants from Denmark and Somalia in Sweden - presumably the issue is to a large extent about being "non-white", but also the level of economic development of the country of origin. Furthermore, this effect also depends on how 
of immigrant status is defined (e.g. whether children of immigrants are classified as having immigrant status, whether it is taken into account how many years are spent in the country, refugee or labour migrant, etc.). A priori it seems likely that the importance of immigrant status is decreasing with time, i.e. for most variables time spent in the new country will decrease the difference relative to the average of the locally born population. In this regard immigration status is different from ethnicity: it changes with time. 
Figure 3.1Population proportion with two foreign born parents in Norway, by background. Source: Statistics Norway

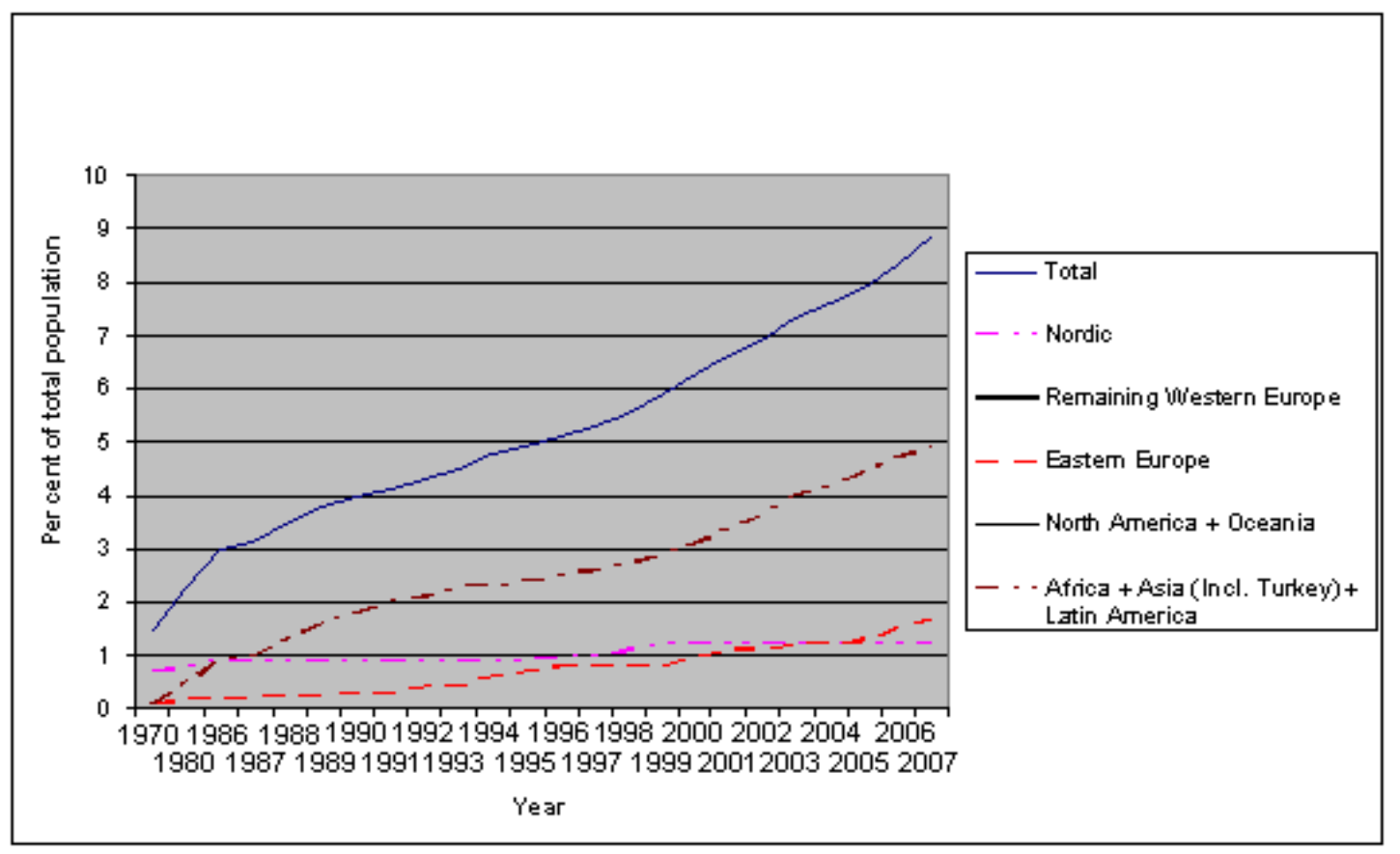

Figure 3.1 and Table 3.1 demonstrate the importance of immigrants in Norway and Sweden, and give an impression of the geographical origin and age composition of the immigrant population. It is worth noting that the low number of young people in Table 3.1 reflects the low mobility of young people, and would probably have been much higher if the definition applied by Statistics Norway, i.e. having two foreign born parents, had been used. 
Table 3.1 Proportion and number of foreign born population in Sweden in 2001 by age group.

\begin{tabular}{|l|r|r|}
\hline Age Group & Proportion & Thousands \\
\hline 0-4 years & $2.3 \%$ & 10 \\
\hline $5-14$ years & $5.5 \%$ & 64 \\
\hline 15-24 years & $11.3 \%$ & 117 \\
\hline 25-34 years & $14.5 \%$ & 174 \\
\hline 35-44 years & $16.6 \%$ & 205 \\
\hline 45-54 years & $14.6 \%$ & 177 \\
\hline $55-64$ years & $12.2 \%$ & 132 \\
\hline $65-74$ years & $12.4 \%$ & 91 \\
\hline $75-84$ years & $7.9 \%$ & 46 \\
\hline 85-94 years & $5.1 \%$ & 9 \\
\hline 95+ years & $5.3 \%$ & 1 \\
\hline Total & $11.5 \%$ & 1028 \\
\hline
\end{tabular}

(Source: Statistics Sweden)

Table 3.2 New Zealand population by birthplace and ethnicity 2001

\begin{tabular}{|c|c|c|c|c|c|c|c|}
\hline 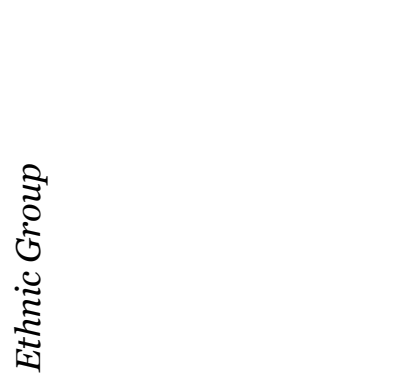 & 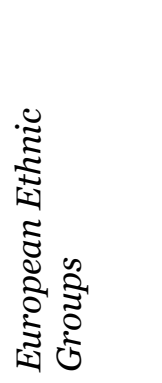 & 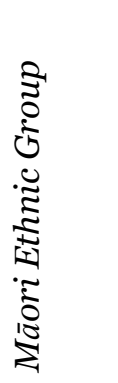 & 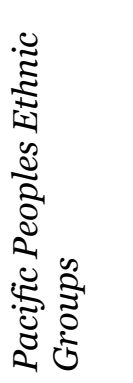 & 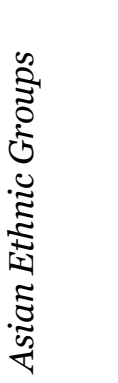 & 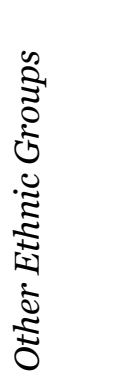 & 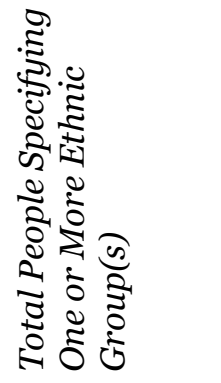 & 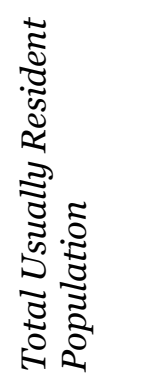 \\
\hline Share of total population & $76.8 \%$ & $14.1 \%$ & $6.20 \%$ & $6.37 \%$ & $0.67 \%$ & $95.97 \%$ & $100.00 \%$ \\
\hline \multicolumn{8}{|l|}{ By birthplace } \\
\hline New Zealand & $85.6 \%$ & $97.5 \%$ & $57.7 \%$ & $22.4 \%$ & $20.1 \%$ & $80.2 \%$ & $77.4 \%$ \\
\hline Australia & $1.8 \%$ & $0.9 \%$ & $0.7 \%$ & $0.3 \%$ & $0.7 \%$ & $1.5 \%$ & $1.5 \%$ \\
\hline Pacific Islands & $0.2 \%$ & $0.1 \%$ & $40.2 \%$ & $8.7 \%$ & $0.2 \%$ & $3.3 \%$ & $3.2 \%$ \\
\hline UK and Ireland & $7.7 \%$ & $0.2 \%$ & $0.1 \%$ & $0.4 \%$ & $2.0 \%$ & $6.2 \%$ & $6.0 \%$ \\
\hline Rest of Europe & $2.0 \%$ & $0.0 \%$ & $0.1 \%$ & $0.1 \%$ & $1.3 \%$ & $1.6 \%$ & $1.6 \%$ \\
\hline North America & $0.7 \%$ & $0.1 \%$ & $0.2 \%$ & $0.3 \%$ & $2.7 \%$ & $0.6 \%$ & $0.6 \%$ \\
\hline Asia & $0.3 \%$ & $0.1 \%$ & $0.1 \%$ & $65.8 \%$ & $1.0 \%$ & $4.6 \%$ & $4.4 \%$ \\
\hline Other & $1.1 \%$ & $0.0 \%$ & $0.0 \%$ & $1.4 \%$ & $71.2 \%$ & $1.4 \%$ & $1.4 \%$ \\
\hline Total Overseas & $13.8 \%$ & $1.4 \%$ & $41.5 \%$ & $77.1 \%$ & $79.2 \%$ & $19.2 \%$ & $18.7 \%$ \\
\hline Missing & $0.6 \%$ & $1.1 \%$ & $0.1 \%$ & $0.6 \%$ & $0.8 \%$ & $0.7 \%$ & $4.0 \%$ \\
\hline Total in thousands & 2871 & 526 & 232 & 238 & 25 & 3587 & 3737 \\
\hline
\end{tabular}

(Source: 2001 Census, Statistics New Zealand) 
In table 3.2 birthplace and ethnicity of the New Zealand resident population are analysed. As opposed to the other datasets used in the thesis this contains missing data, and is thus repeated here. In the other datasets missing data has already been corrected for. In the rest of the thesis Maori and Pacific island ethnicity is prioritised by the dataset, meaning that those who give multiple ethnicities are counted as Maori or Pacific Islander. The columns provide the ethnic composition of the total population in the top row, and in the rows below that the relative frequency of birthplace for each ethnic group is provided. The two rightmost columns provide the birthplace of the total resident population, and of the two the rightmost only includes the individuals that specified their ethnic affiliation. The table shows that New Zealand has more ethnic diversity than Scandinavia both through immigration and the indigenous Māori minority: The proportion of foreign born inhabitants is a third larger than that of Sweden, and the number of Māori people is large enough to make a notable impact on statistics where they differ from the mean, which is unlikely to be the case for Sami in Sweden and Norway, with a possible exception for language.

LIS-data for Norway and Sweden are used to show the correlation between immigrant status and poverty among families with children. Again, in this chapter the focus is on market income. It is appropriate to start with market income before actual disposable income because it describes the problem the governments are trying to solve through the tax and benefits system.

According to the 2000 Norwegian survey, out of the 172 ooo households with some form of immigrant background (12.0 \% of total number of households), 80 ooo or 31.7 per cent was poor, while the proportion was 36.2 per cent for the total population. This includes the households where either the head or spouse of head falls into one of the following categories: 'first generation immigrant without Norwegian background', 'born in Norway with two foreign born-parents', 'adopted from abroad', 'born abroad, on Norwegian parent', 'born in Norway one foreign-born parent' or 'born abroad, two Norwegian parents'. Immigrants are in other words better off. Sections 3.3 and 3.4 below explores whether this is due to some other spurious factor, i.e. whether age and family size changes this picture. The Norwegian dataset allows a limitation of immigrant classification to those with 'first generation immigrant without Norwegian background'. This lowers the number of households with immigrant head or spouse to 165 ooo, of which 60 ooo or 36.0 per cent were 
poor. It is also possible to look at the poverty gap to see if those immigrants who are poor are poorer than the rest of the poor population. It appears that it is slightly so in Norway: the poverty gap, which in section 2.1 was defined as the average gap between actual income and the poverty line, in poor households in the entire population extends to 24.8 per cent of the poverty line, while if only looking at households where head or spouse is 'first generation immigrant without Norwegian background', the equivalent number is 25.7 per cent. ${ }^{13}$

The equivalent definitions are applied in Sweden. For Sweden the numbers from the same year shows that out of the 694 ooo households with some form of immigrant background (16.1 per cent of total number of households) 290 ooo, or 41.8 per cent were poor, compared to 39.9 per cent in the total population. The poverty gap is 29.1 per cent of the poverty threshold in the total population, but slightly higher among immigrants: 31.8 per cent.

The dataset contains a variable on ethnicity and data both on market and disposable income, again market income is used in this chapter. Statistics New Zealand uses the Revised Jensen Equivalence scale (Jensen, 1988) (see appendix 7.1 for details). For New Zealand the ethnicity of the household head is used to determine the household's ethnicity. According to the 2001 HES data, out of 1100 ooo European households (80.0 per cent of total), 341 ooo or 30.9 per cent were poor. Out of the 154 ooo households with a Māori head (11.2 per cent of total), 68 ooo or 44.1 per cent were classified as poor. The number for Pacific Island households were 22000 or 45.4 per cent poor out of a total of 48 ooo households (3.6 per cent of total). Perhaps the most interesting finding is that it is in the 'other' category, which Table 3.2 shows is predominantly people of Asian ethnicity (Asian is not a distinct ethnic group in the 2001 HES dataset), has the lowest percentage of poor households: 27.1 per cent (19 ooo out of 72000 households, which in turn is

\footnotetext{
${ }^{13}$ However, when observations where market income is negative are excluded the picture looks marginally different. These are 16000 cases where farm and non-farm self-employment is negative, and it is difficult to tell whether these households are in fact living in poverty. Firstly, the poverty threshold grows by $1.0 \%$. The immigrant population changes from $7.9 \%$ to $7.8 \%$ (a negative market income is in other words less common among immigrants). The poverty rate changes to $35.9 \%$ in the total population and $35.1 \%$ among the 'first generation' immigrant households. In other words the difference between the groups increase six fold compared to when households with negative market income are included, albeit from a very small starting point (difference). Because of the changes in poverty line the poverty gap does in fact decrease, and the difference between immigrants and total population all but disappears: the total average poverty gap is $24.2 \%$ of the poverty line both among the total population as well as among immigrants. Because of this limited impact in Norway analysis of negative market income and various definitions of immigrants, these are not run in Sweden.
} 
5.2 per cent of total). For the total number of households the poverty ratio was 32.7 per cent.

The New Zealand data used here were derived from the HES by the New Zealand Poverty Measurement Project applying their methodology. In other words both these New Zealand and the Scandinavian data are applied to a different cause than what they were intended for, as neither were constructed for the purpose of analysing market poverty through the lenses of ethnicity. This means that the size is limited and creates some uncertainties.

In conclusion, the data imply that Norway had the smallest group of immigrants, and that this group had the lowest poverty incidence when assuming that the households are otherwise comparable. Sweden had a significantly larger group of immigrants. This group was more likely to be poor, and those that were poor were poorer than ethnic Swedish households that were also below the poverty line. The data for New Zealand households contained more data on ethnicity, allowing for four groups of ethnic affiliation painting a more nuanced picture. New Zealand households had an even higher degree of diversity in both birthplace and ethnicity. It does, however, also describe a situation where ethnicity is a strong predictor of poverty. The frequency tables sharply indicates that this is much more so for child poverty than household poverty, and also that immigrant background explains twice as much of the variation in child poverty rates across households in Sweden as it does in Norway. 


\subsection{Family structure and age}

This section will explore how difference in family structure and age affects poverty rates. In consecutive order it will discuss how poverty is affected by the number of children, family type, the correlation poverty rates and poverty depth, having elderly people in the household, and the age of the household head. The next section will analyse how the effect of family structure and age influence the effect of ethnicity/immigrant status. Again, the dependent variables will be poverty rates and poverty gap based on market income. Another important variable to take into account when looking at household poverty rates is household size, as this differs across the countries. For convenience, the data will be arranged by country in a fixed order, starting with New Zealand followed by Norway with Sweden last.

Chapter 4 will run these analyses for disposable income in order to tell which households benefited the most from government intervention. Chapter 5 will explore to what extent differing family type composition could explain the differing poverty rate: by counterfactual analyses of for example looking at what the New Zealand child poverty rate would be if the poverty rate for each type of family structure remained constant, but children were distributed between the different family types by the composition found in Norway and Sweden.

Of course, poverty rates exist in the context of demographic structures that differs across countries. 
Table 3.3 Age structure

\begin{tabular}{|l|r|r|r|}
\hline Age & New Zealand & \multicolumn{1}{l|}{ Norway } & \multicolumn{1}{l|}{ Sweden } \\
\hline $0-9$ & $14.9 \%$ & $13.7 \%$ & $11.7 \%$ \\
\hline $10-19$ & $14.9 \%$ & $12.3 \%$ & $12.3 \%$ \\
\hline $20-29$ & $13.0 \%$ & $13.7 \%$ & $12.4 \%$ \\
\hline $30-39$ & $15.4 \%$ & $15.2 \%$ & $14.1 \%$ \\
\hline $40-49$ & $14.4 \%$ & $14.0 \%$ & $13.1 \%$ \\
\hline $50-59$ & $11.2 \%$ & $12.1 \%$ & $13.8 \%$ \\
\hline $60-69$ & $7.6 \%$ & $7.8 \%$ & $9.2 \%$ \\
\hline $70-79$ & $5.7 \%$ & $7.2 \%$ & $7.8 \%$ \\
\hline $80+$ & $2.9 \%$ & $4.2 \%$ & $5.6 \%$ \\
\hline Total & 3737000 & 4478000 & 830000 \\
\hline
\end{tabular}

Sources: Statistics New Zealand: Census Usually Resident Population Count 2001

Statistics Norway: Folkemengd, etter kjønn og alder, 2000

Statistics Sweden: Befolkningen efter region, civilstånd, ålder och kön, 2000

The three countries had a relatively similar share of the population between 20 and 59 years of age: lowest in Sweden on 53.4 per cent, highest in Norway on 54.8 per cent and New Zealand in the middle on 54.0 per cent. The difference between New Zealand and Scandinavia was larger when it came to the share of individuals under 20 years, which were substantially higher in New Zealand (29.8 per cent), lowest in Sweden (24.0 per cent), which was not much lower than lower than Norway on 26.0 per cent. This means, of course, that New Zealand had the lowest share of the population over 59 (16.2 per cent) - over a quarter less than in Sweden (22.6 per cent), and nearly a fifth less than in Norway (19.3 per cent) 
Figure 3.2 Fertility rate by mothers' age in year $\mathbf{2 0 0 0}^{14}$

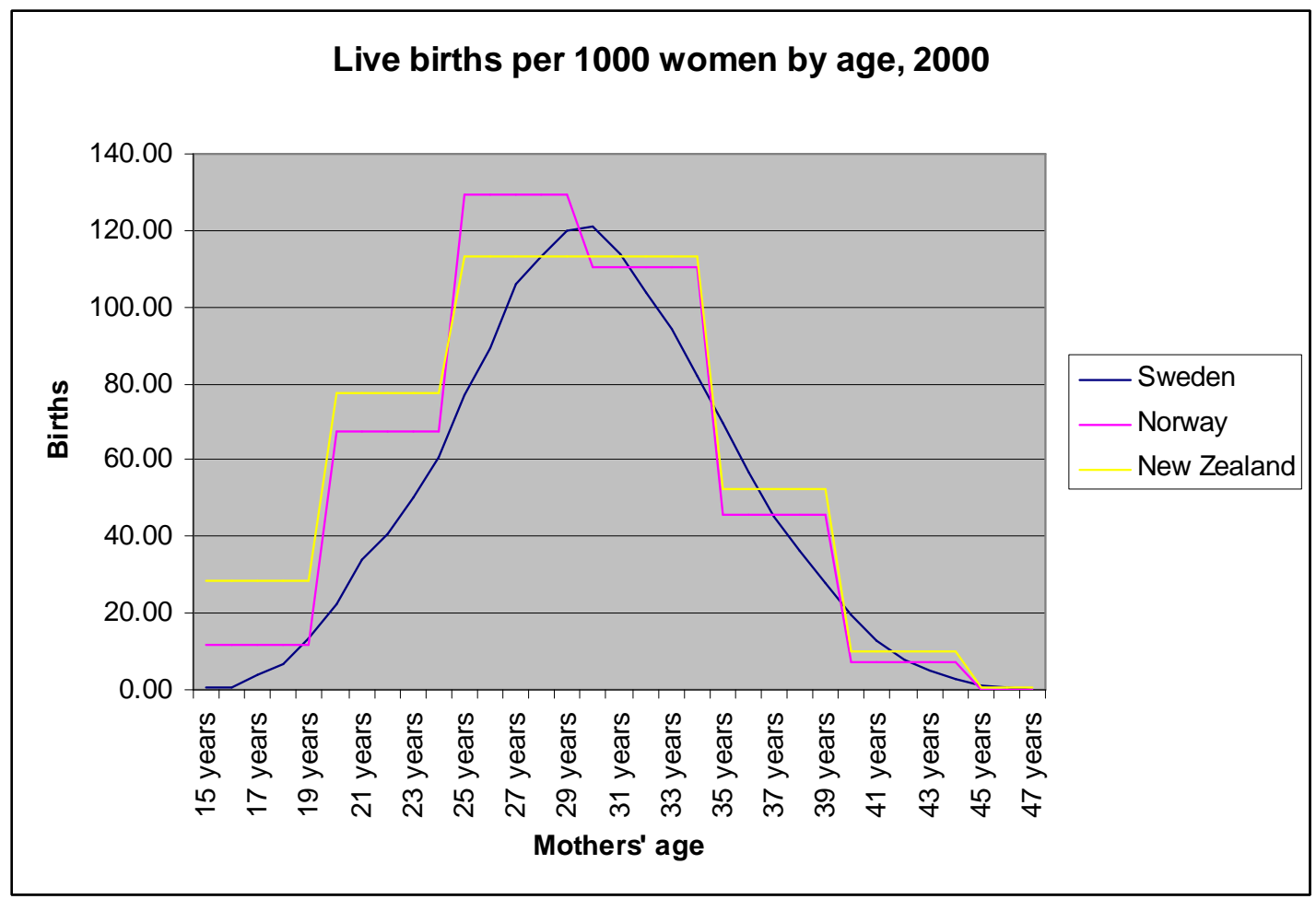

Sources:

- Statistics New Zealand: Demographic trends 2006; Age specific fertility rates, 1962-2005

- Statistics Norway: Statistisk årbok 2001: Fruktbarhet, etter mors alder

- Swedish calculation based on:Statistics Sweden: Befolkningen i riket efter civilstånd, ålder och kön. År 1968-20o6 and Levande födda efter region, kön och moderns ålder. År 1968-20o6

The fertility rate is important for at least two reasons. First, the higher fertility rate in New Zealand (1.98 per woman, compared to 1.85 in Norway and 1.55 in Sweden) shows that higher immigration levels was not the only explanation for New Zealand's more youthful population. Indeed, through annual variation, New Zealand's fertility rate has consistently been the highest among the three countries in the 1993-2005 period (Statistics New Zealand, 2007:48). It is particularly noteworthy that the higher rate was found among young New Zealand women (i.e. those under 25). At their most fertile age the fertility rate of Swedish and Norwegian women (those between 25 and 29) was actually higher than among their New Zealand counterparts. For example, the birth rate per 1000 15-19 year-old women were 28.2 in New Zealand, contrasted to 11.7 in Norway, and 13.5 among Swedish 19 year-old women only, and much lower among those under 19. Second, this means simply that New Zealand has a higher number of children per household, woman and

${ }^{14}$ Self-evidently, age group categories are used for the New Zealand and Norwegian data. 
thus probably also per income earner. As later sections will show, this is important because as two adult families gain children it is in most cases possible to increase the income in the market sufficiently to stay above the poverty line. However, when the number of children surpasses three it becomes more of a problem to continue raise the market income sufficiently without government transfers.

As it deals specifically with age, this section is where it is natural to start focusing on child poverty rates. Another group whose poverty is often studied in detail is the elderly. This is an interesting parallel to child poverty, as that is the other age group that mostly fall outside the workforce. However, it is beyond the scope of this thesis to focus much on the poverty among the elderly, although they will be briefly mentioned as part of the statistics on poverty in various age categories. The correlation of child, elderly and overall poverty has been the matter of some debate. In his own words, Brady (2004:503)

\footnotetext{
"challenges the claims regarding divergence in elderly, child and overall poverty. [... O]verall and child poverty are very strongly correlated with each other, whereas elderly poverty has a less strong positive correlation with those two. The elderly and children are more likely to be poor than the overall population. Both the elderly and children are more vulnerable to experience economic insecurity and low household incomes than working-age adults. Nevertheless, elderly poverty and child poverty do not really cross-nationally and historically diverge from overall poverty or from each other. Countries that experience high levels of overall poverty also tend to experience high levels of child poverty and, to a somewhat lesser extent, elderly poverty. When overall poverty increases in a country, child and elderly poverty also increase."
}

That child poverty is closely related to overall poverty is hardly surprising given that most children live in households shared with adults.

As already indicated, this section will count households like in the previous section in order to compare families with and without children. In order to put the total poverty rate in perspective a brief comparison with the poverty rate among the elderly and the child poverty rate among households with elderly people are also provided.

The New Zealand 2000/2001 HES data use the following categories for family structure: 


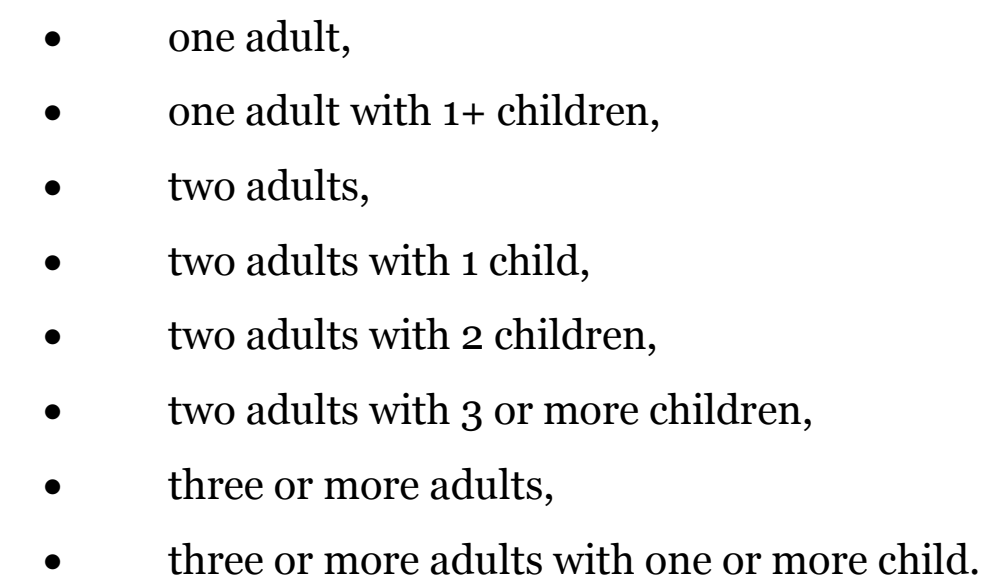

It also contains categories for number of children in household ( $0 ; 1 ; 2 ; 3$; $4 ; 5$ or more) and number of persons over 60 years of age (o; $1 ; 2$ or more), while the Norwegian and Swedish LIS datasets counts the number of persons above 65. While this discrepancy is not ideal it should still provide a comparable picture. Age categories for household head are also provided in seven different groups.

It is unfortunate that it does not provide any specified statistics for children in various age groups, because as highlighted in chapter 2 , the consequences of child poverty seems to depend on the age at which it is experienced. For each of all the categories above the total and poor number of and percentage of households, persons and children, as well as poverty gap is given. This gives a reasonably full picture, with a lot of information that may be presented in several ways, even though there are some combinations of variables that cannot be observed directly. Except for the different upper age threshold, all the equivalent information is available for Norway and Sweden in the LIS dataset. Again, a 60 per cent poverty threshold is used. This was complemented by a measure of the poverty gap, to give an image of the depth of the poverty, but did not give a significantly different image than the poverty rate, and was thus ultimately excluded. For Norway and Sweden a square root equivalence scale is used, and the Revised Jensen Equivalence scale is intrinsic to the HES, but is impractical to implement into the LIS dataset. As commented above, appendix 6.1 provides an overview of the discrepancies this causes. 
Table 3.4A Market income household (HH) and child poverty in New Zealand by number of children

\begin{tabular}{|c|c|c|c|c|c|}
\hline 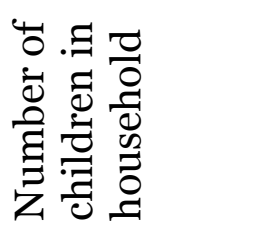 & 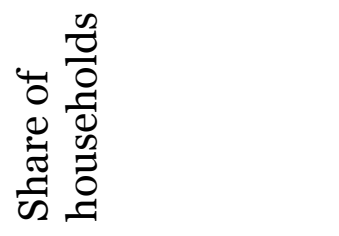 & 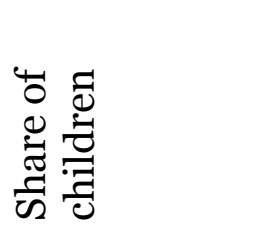 & 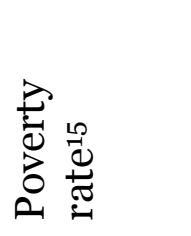 & 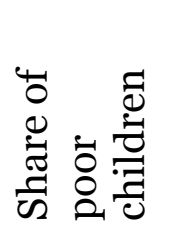 & 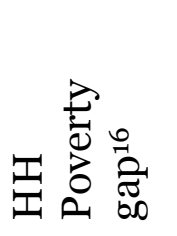 \\
\hline 0 & $66.1 \%$ & - & $35.3 \%$ & - & $78.4 \div$ \\
\hline 1 & $13.2 \%$ & $20.4 \div$ & $27.4 \%$ & $18.7 \%$ & $61.6 \div$ \\
\hline 2 & $13.5 \%$ & $42.0 \div$ & $24.9 \%$ & $34.9 \%$ & 66.7 \\
\hline 3 & $5.2 \%$ & $24.3 \%$ & $26.2 \%$ & $21.2 \%$ & $54.6 \div$ \\
\hline 4 & $1.4 \%$ & $8.7 \%$ & $45.1 \%$ & $13.1 \%$ & $65.3 \div$ \\
\hline $5^{+}$ & $0.6 \%$ & $4.7 \%$ & $77.6 \%$ & $12.1 \%$ & $75.5 \div$ \\
\hline All households & $1374 \quad 000$ & 886000 & $29.9 \%$ & 265000 & $74.1 \div$ \\
\hline
\end{tabular}

(Source: HES 2001)

As seen in the table above households with one, two or three children have lower poverty rates than those with no children, but those with four or five has higher and double the rate, respectively. The tables below will indicate that the high poverty rate in households without children is largely due to the elderly population. As is confirmed below, poverty is not a particularly common problem in working age households without children. On the other hand, among the poor households, those that are the furthest below the poverty threshold are among those without children. The child poverty rate is only slightly lower than for the total number of households.

15 The poverty rate is weighted by children in all but the top case, where it weighted by households, in this and the two following tables.

${ }^{16}$ In this thesis, poverty gap is to be understood as the average gap between actual income and poverty threshold among the poor households as a share of the poverty threshold. In other words, if the threshold is $\$ 10$ ooo, and the poor households (those earning less than $\$ 10$ o00) on average earn $\$ 8$ ooo, the gap would be $20 \%$. 
Table 3.4B Market income household (HH) and child poverty in Norway by number of children

\begin{tabular}{|c|c|c|c|c|c|}
\hline 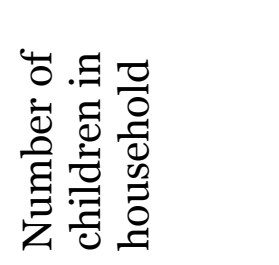 & 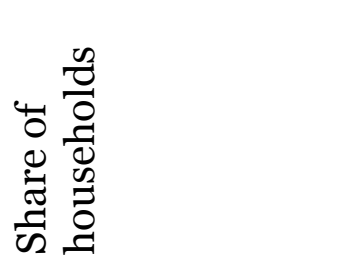 & 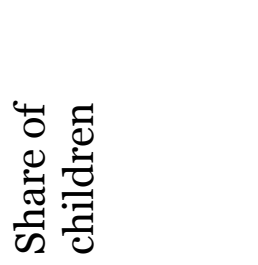 & 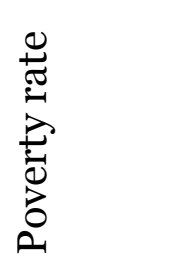 & 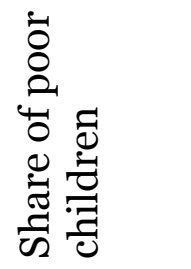 & 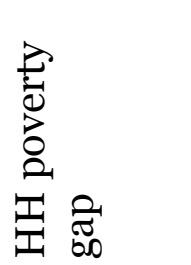 \\
\hline $\mathrm{O}$ & $72.0 \%$ & - & $43.6 \%$ & & $24.8 \%$ \\
\hline 1 & $12.1 \%$ & $24.0 \%$ & $19.9 \%$ & $29.0 \%$ & $19.7 \%$ \\
\hline 2 & $10.8 \%$ & $43.1 \%$ & $14.7 \%$ & $38.5 \%$ & $10.8 \%$ \\
\hline 3 & $4.3 \%$ & $25.4 \%$ & $12.6 \%$ & $19.5 \%$ & $6.1 \%$ \\
\hline 4 & $0.6 \%$ & $5.1 \%$ & $25.5 \%$ & $7.9 \%$ & $10.8 \%$ \\
\hline $5^{+}$ & $0.2 \%$ & $2.4 \%$ & $36.0 \%$ & $5.1 \%$ & $19.7 \%$ \\
\hline All households & 2093000 & 1051000 & $16.5 \%$ & 173000 & $24.8 \%$ \\
\hline
\end{tabular}

(Source: LIS 2000)

The central figure of these three tables is the total poverty rate, which is weighted by children for all but the top column for the households without children, where household poverty is used. According to HES data almost three out of ten New Zealand children lived in households with market incomes under the poverty line used in this thesis. The equivalent figure for Norway was just below one sixth, while it was exactly a fifth in Sweden. 
Table 3.4C Market income household and child poverty in Sweden by number of children

\begin{tabular}{|c|c|c|c|c|c|}
\hline 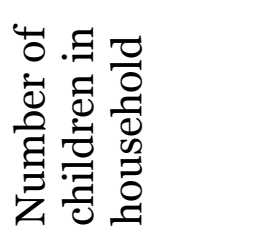 & 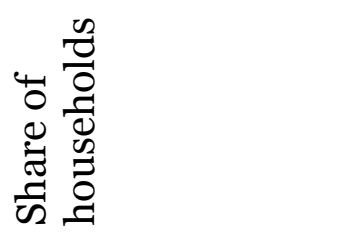 & 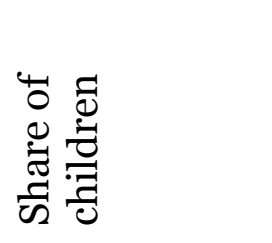 & $\begin{array}{l}\overrightarrow{0} \\
\overline{0} \\
0 \\
0 \\
0 \\
0 \\
0 \\
0\end{array}$ & 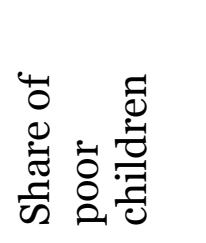 & 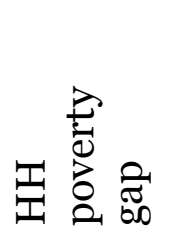 \\
\hline 0 & $75.1 \%$ & - & $46.7 \%$ & - & $34.6 \%$ \\
\hline 1 & $10.3 \%$ & $22.9 \%$ & $20.1 \%$ & $23.0 \%$ & $13.4 \%$ \\
\hline 2 & $10.3 \%$ & $45.8 \%$ & $17.0 \%$ & $38.9 \%$ & $10.4 \%$ \\
\hline 3 & $3.3 \%$ & $22.2 \%$ & $18.2 \%$ & $20.1 \%$ & $11.2 \%$ \\
\hline 4 & $0.7 \%$ & $6.6 \%$ & $28.4 \%$ & $9.3 \%$ & $20.4 \%$ \\
\hline $5^{+}$ & $0.2 \%$ & $2.6 \%$ & $67.2 \%$ & $8.7 \%$ & $50.9 \%$ \\
\hline All households & 4327000 & 1951000 & $20.0 \%$ & $390 \quad 000$ & $29.1 \%$ \\
\hline
\end{tabular}

(Source: LIS 2000)

When comparing the table of New Zealand data with the Scandinavian equivalents two factors stand out. First of all, the larger poverty gap in New Zealand, which was also less evenly spread out. In part this is because of differing definitions of social insurance as market income and transfers, in the LIS dataset occupational pensions are included in market income. This gives lower market income for older households in New Zealand where most retired people rely on the universal old-age pension which is counted as a transfer. This affect poverty rates and the poverty gap measure, especially for households with retired people, i.e. primarily those with no children, and old household heads. In other words, even though slightly fewer people fell below the 60 per cent of median poverty threshold, those that did fall below it is so far below it that one can safely presume that most of them have no market income at all. The second factor is that the households without children were a smaller share of the poor households in New Zealand (71.3 per cent, not in table) than in Norway (86.8 per cent) and Sweden (88.0 per cent). This was a result of the combined effect of higher probability of poverty among childless households and childless households being more widespread. Except the families with five or more children in Sweden, the number of children seemed to matter less in Scandinavia than in New Zealand. Having four or more children was more common in New Zealand than in Scandinavia. There was a clear trend indicating that the households with two or three children were better off than those with one, four, or more than four children.

Beyond that there is a striking lack of linear trends in the poverty gaps and household poverty rates. This probably reflects that the number of children is a 
rather crude variable that needs to be complimented with other factors as well. Part of this crudeness is that the number of children does not say anything about the number of adults, and thus the number of potential earners. This is a crucial factor, especially when looking at market income.

The table below shows the most common family types in terms of numbers of people over and under 18 years of age.

Table 3.5A New Zealand market income poverty rate by family type

\begin{tabular}{|c|c|c|c|c|c|c|}
\hline & 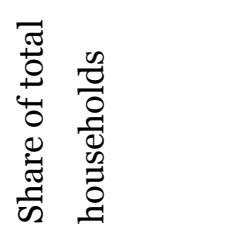 & 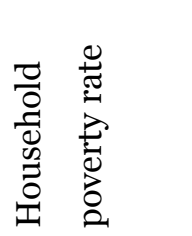 & 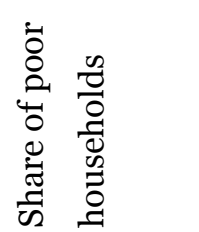 & 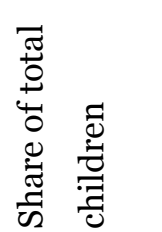 & 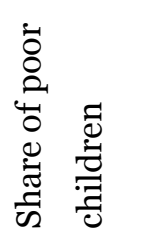 & 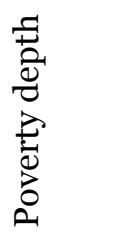 \\
\hline 1 adult & $23.4 \%$ & $54.3 \%$ & $38.7 \%$ & - & - & $83.7 \%$ \\
\hline 1 adult 1 or more child & $5.0 \%$ & $78.4 \%$ & $12.1 \%$ & $14.2 \%$ & $39.6 \%$ & $74.0 \%$ \\
\hline 2 adults & $30.3 \%$ & $30.7 \%$ & $28.4 \%$ & - & - & $73.8 \%$ \\
\hline 2 adults 1 child & $6.2 \%$ & $19.1 \%$ & $3.6 \%$ & $9.6 \%$ & $6.1 \%$ & $57.0 \%$ \\
\hline 2 adults 2 children & $9.6 \%$ & $16.5 \%$ & $4.8 \%$ & $29.6 \%$ & $16.3 \%$ & $57.3 \%$ \\
\hline $\begin{array}{l}\text { adults } 3 \\
\text { Or more children }\end{array}$ & $5.0 \%$ & $21.4 \%$ & $3.2 \%$ & $25.3 \%$ & $19.6 \%$ & $43.0 \%$ \\
\hline 3 or more adults & $12.5 \%$ & $11.1 \%$ & $4.2 \%$ & - & - & $60.5 \%$ \\
\hline $\begin{array}{l}3 \text { or more adults } \\
1 \text { or more children }\end{array}$ & $8.1 \%$ & $19.8 \%$ & $4.9 \%$ & $21.4 \%$ & $18.3 \%$ & $60.4 \%$ \\
\hline
\end{tabular}

(Source: HES 200O) 
Table $3.5 B$ Norwegian market income poverty rate by family type

\begin{tabular}{|c|c|c|c|c|c|c|}
\hline & 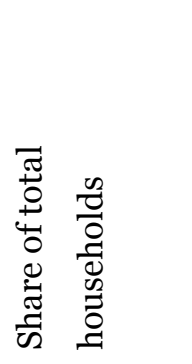 & 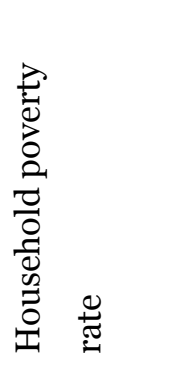 & 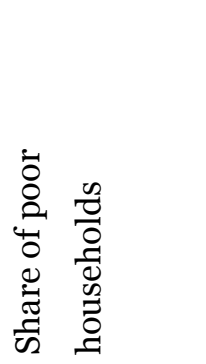 & 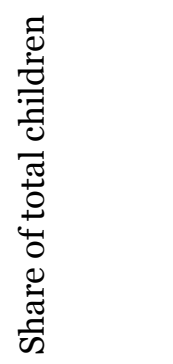 & 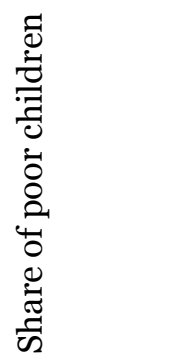 & 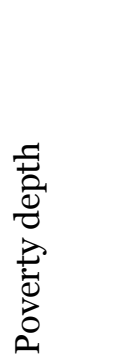 \\
\hline 1 adult & $41.3 \%$ & $54.5 \%$ & $62.3 \%$ & - & - & $40.2 \%$ \\
\hline 1 adult 1 or more child & $5.3 \%$ & $55.9 \%$ & $8.2 \%$ & $15.2 \%$ & $54.2 \%$ & $35.9 \%$ \\
\hline 2 adults & $25.1 \%$ & $33.5 \%$ & $23.2 \%$ & - & - & $20.7 \%$ \\
\hline 2 adults 1 child & $6.4 \%$ & $7.6 \%$ & $1.4 \%$ & $12.8 \%$ & $5.9 \%$ & $3.4 \%$ \\
\hline 2 adults 2 children & $8.4 \%$ & $7.2 \%$ & $1.7 \%$ & $33.5 \%$ & $14.6 \%$ & $3.4 \%$ \\
\hline $\begin{array}{l}2 \text { adults } 3 \\
\text { Or more children }\end{array}$ & $4.4 \%$ & $10.8 \%$ & $1.3 \%$ & $28.2 \%$ & $20.7 \%$ & $3.8 \%$ \\
\hline 3 or more adults & $5.6 \%$ & $8.5 \%$ & $1.3 \%$ & - & - & $4.5 \%$ \\
\hline $\begin{array}{l}3 \text { or more adults } \\
1 \text { or more children }\end{array}$ & $3.5 \%$ & $6.4 \%$ & $0.6 \%$ & $10.4 \%$ & $4.6 \%$ & $2.6 \%$ \\
\hline
\end{tabular}

(Source: LIS 200O)

Table 3.5 C Swedish market income poverty rate by family type

\begin{tabular}{|c|c|c|c|c|c|c|}
\hline & 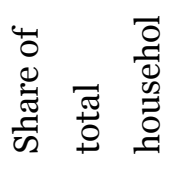 & 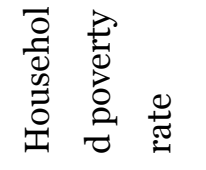 & 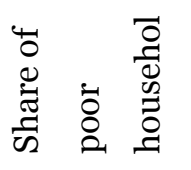 & 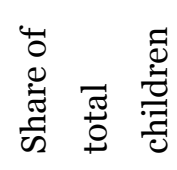 & 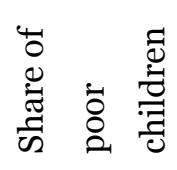 & 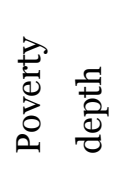 \\
\hline 1 adult & $46.4 \%$ & $55.6 \%$ & $64.8 \%$ & - & - & $43.0 \%$ \\
\hline 1 adult 1 or more child & $5.3 \%$ & $49.3 \%$ & $6.5 \%$ & $19.1 \%$ & $48.9 \%$ & $34.1 \%$ \\
\hline 2 adults & $25.0 \%$ & $35.9 \%$ & $22.5 \%$ & - & - & $23.6 \%$ \\
\hline 2 adults 1 child & $5.8 \%$ & $11.1 \%$ & $1.6 \%$ & $12.9 \%$ & $7.2 \%$ & $6.2 \%$ \\
\hline 2 adults 2 children & $7.9 \%$ & $10.3 \%$ & $2.0 \%$ & $35.1 \%$ & $18.1 \%$ & $6.3 \%$ \\
\hline $\begin{array}{l}2 \text { adults } 3 \\
\text { Or more children }\end{array}$ & $3.4 \%$ & $15.9 \%$ & $1.3 \%$ & $24.5 \%$ & $21.8 \%$ & $8.9 \%$ \\
\hline 3 or more adults & $3.7 \%$ & $7.9 \%$ & $0.7 \%$ & - & - & $4.5 \%$ \\
\hline $\begin{array}{l}3 \text { or more adults } \\
1 \text { or more children }\end{array}$ & $2.6 \%$ & $7.7 \%$ & $0.5 \%$ & $8.5 \%$ & $4.1 \%$ & $4.8 \%$ \\
\hline
\end{tabular}

(Source: LIS 2001)

Taking the number of adults into account shows that among the households with two adults, except for the New Zealand households with three or more children, poverty depth is lowest among those with one child, while the poverty rate is consistently lowest among those with two children. Interestingly, the data 
show that even though New Zealand mothers gave birth at a younger age, children were less likely live in households with only one adult: 14.2 per cent of New Zealand children lived in a one adult household, compared to 15.2 per cent and 19.1 per cent of Norwegian and Swedish children, respectively.

Table $3.5 \mathrm{D}$ Comparing New Zealand with the average of Norway and Sweden (New Zealand share divided by the average share of Norway and Sweden)

\begin{tabular}{|c|c|c|c|c|c|c|}
\hline & 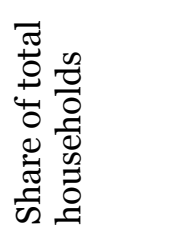 & 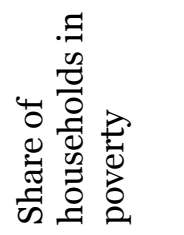 & 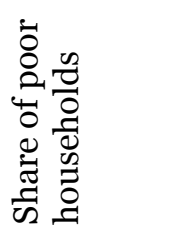 & 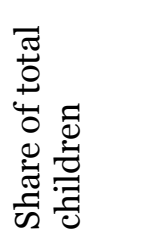 & 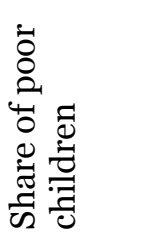 & 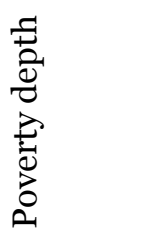 \\
\hline 1 adult & 0.5 & 1.0 & 0.6 & - & - & 1.7 \\
\hline 1 adult 1 or more child & 1.0 & 1.5 & 1.6 & 0.8 & 0.8 & 1.8 \\
\hline 2 adults & 1.2 & 0.9 & 1.2 & - & - & 2.5 \\
\hline 2 adults 1 child & 1.0 & 2.0 & 2.4 & 0.8 & 0.9 & 6.6 \\
\hline 2 adults 2 children & 1.2 & 1.9 & 2.6 & 0.9 & 1.0 & 6.9 \\
\hline $\begin{array}{l}2 \text { adults } 3 \\
\text { Or more children }\end{array}$ & 1.3 & 1.6 & 2.4 & 1.0 & 0.9 & 3.5 \\
\hline 3 or more adults & 2.7 & 1.4 & 4.2 & - & - & 9.8 \\
\hline $\begin{array}{l}3 \text { or more adults } \\
1 \text { or more children }\end{array}$ & 2.7 & 2.8 & 8.8 & 2.3 & 4.2 & 9.6 \\
\hline
\end{tabular}

(Source: LIS 200O, HES 200O)

The table above shows that the only family type where the New Zealand poverty rate was lower than the average of that of Norway and Sweden was the two adults, no children type (the New Zealand poverty rate was equivalent to 0.9 of the Scandinavian average), while the share of poor household in the 3 adults with children type was almost three times higher in New Zealand than the Scandinavian average. The one adult only family type carried a smaller share of the poor households in New Zealand, while all other types carried a larger share of the total number of poor households than Scandinavia. And as already pointed out, the poverty gap is almost ten times bigger in New Zealand 3 adult households than among equivalents in Scandinavia.

An interesting question the combination of poverty rates and poverty gaps raises is whether the two variables followed a similar pattern across family types. In other words, were family types where poverty was most widespread also the 
family types where poverty was deepest? This would have implications both for poverty policy and measurement. If deep poverty is concentrated in groups where the poverty rate is not particularly high, it is necessary to include the poverty depth in addition to the poverty rate, otherwise the given poverty threshold and the poverty rate it produces will present a distorted picture. It would also affect which policy solutions that may be viable. If market income poverty depth is high, that is an indication of low employment rates, and policy efforts should be directed here, whereas if a large number of people in the particular group are just below the poverty line, the efforts should be directed towards increased transfers and possibly higher minimum wages, or other policies that could increase pay. The following three figures display the relationship between poverty prevalence and poverty depth in various family types in the three countries:

Figure $3.3 A^{17}$

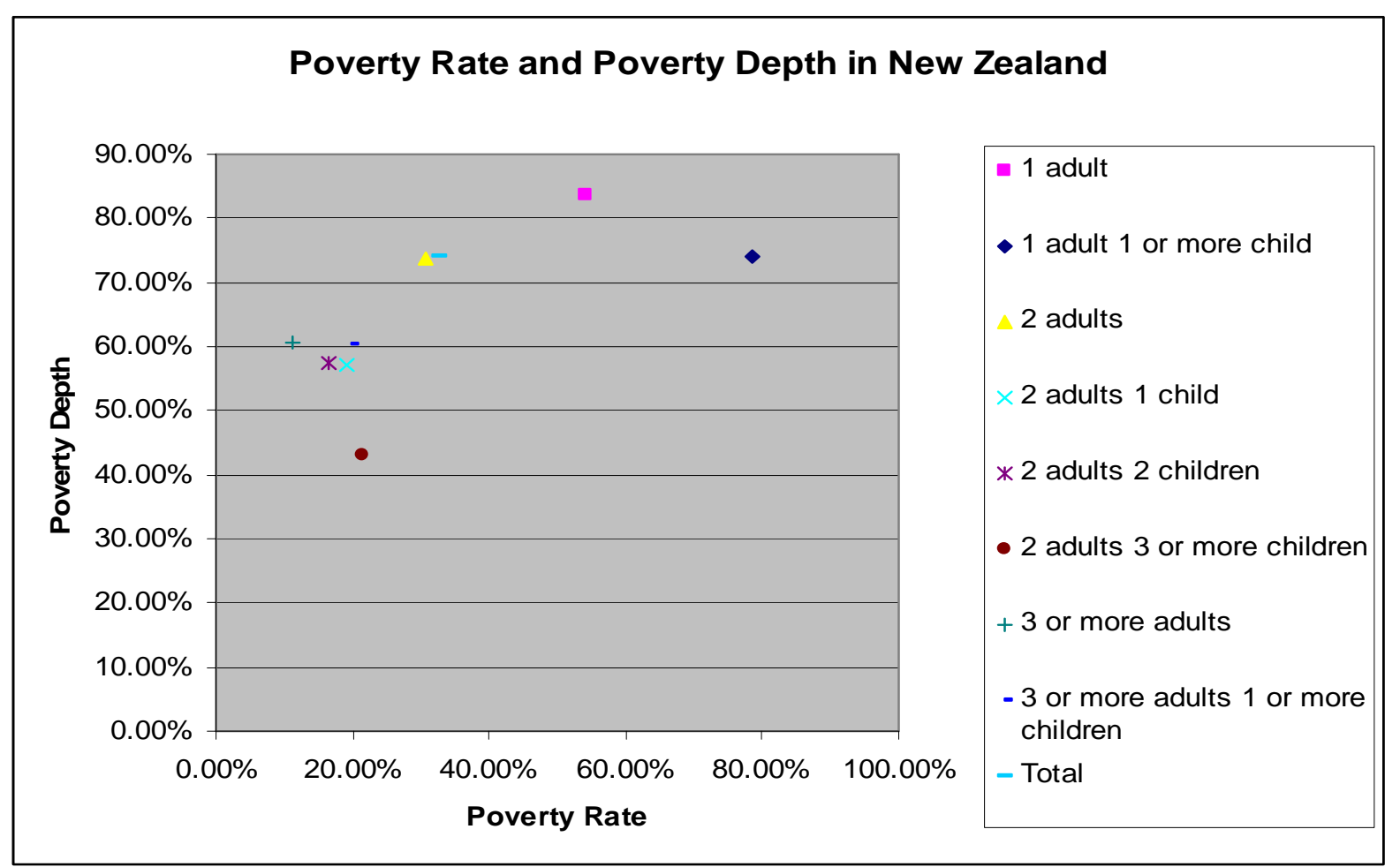

\footnotetext{
17 Due to the purpose of these three figures the scales are different. The purpose is not primarily to illustrate the poverty rate and depth in the three countries, but (in simplistic way) to explore whether the relation between the two variables approach linearity.
} 
Figure $3.3 B$

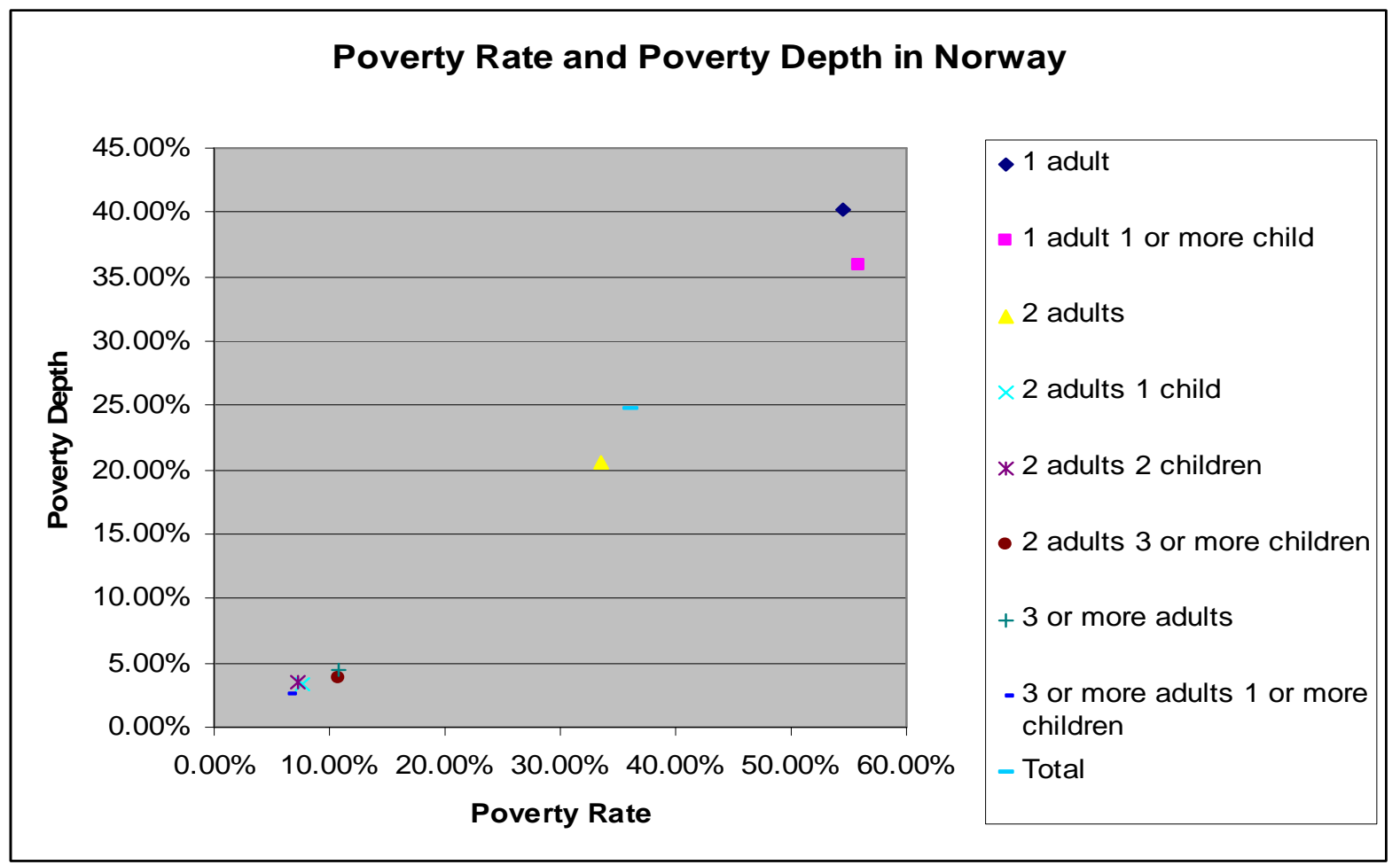

Figure $3.3 C$

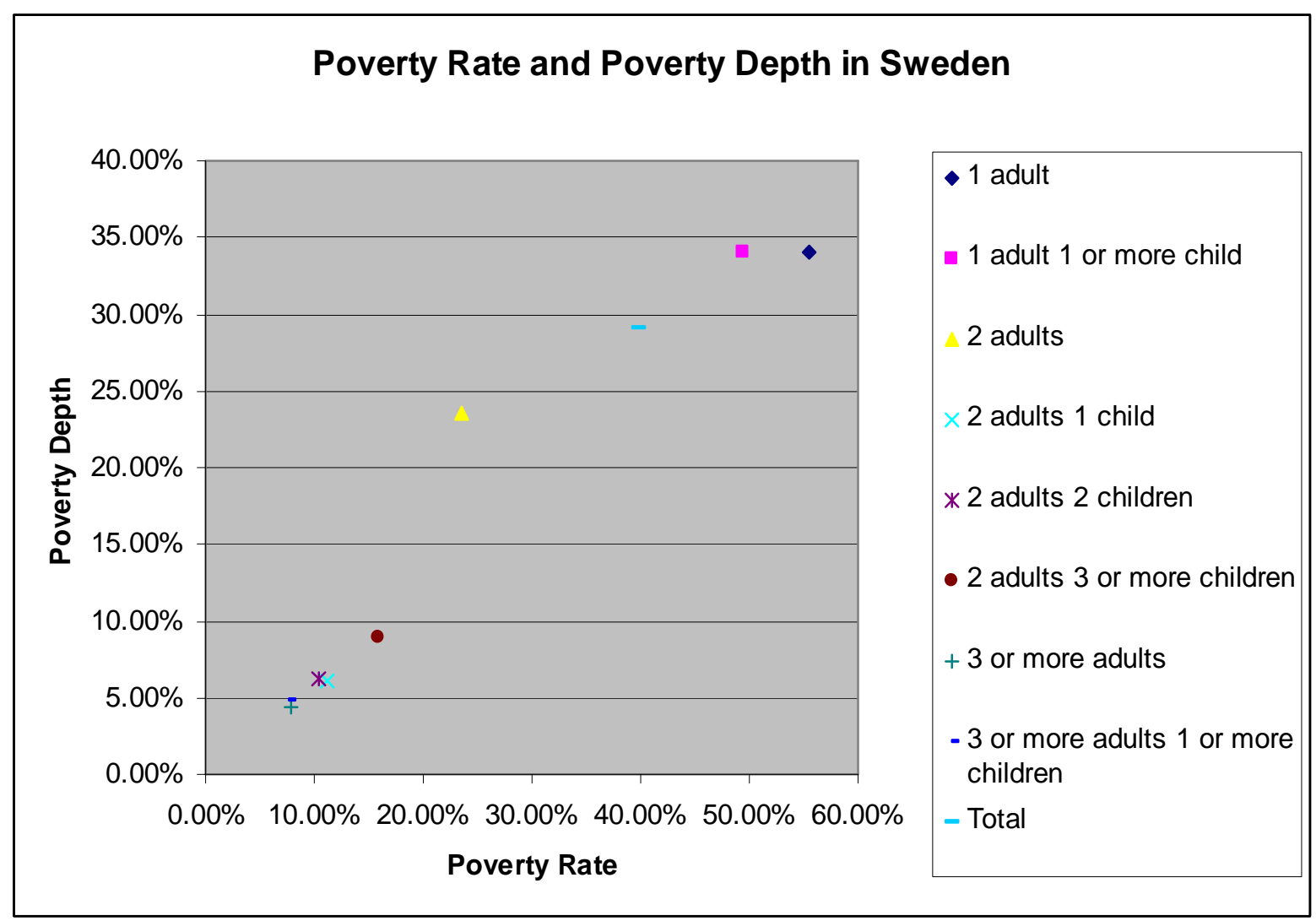

Recall that the poverty rate describes the proportion of the population with an income below the poverty threshold, while poverty depth measures how 
much below the line this income on average is. While the relation between the poverty rate and poverty depth is clearly not fully linear, the relationship does not seem to be significantly disproportionate in any of the family types, either. In New Zealand there is a trend towards childless families being deeper in poverty than the poverty rate indicates, and vice versa for families with children. Testing for a larger number of variables other than family type in the data from Norway and Sweden (not shown in figures) confirmed the impression that at least in Norway and Sweden the correlation between poverty depth and poverty rate was almost linear. The more ambiguous relationship in the New Zealand data could be a reflection of the fact that the depth of poverty in New Zealand was nearly three times that of Norway and Sweden.

The tables showing the share of households in different family types makes it clear that small households were more common in Scandinavia, while larger households were relatively more common in New Zealand. This means that even though the poverty rate was only slightly higher among families of the three first types in New Zealand than in the two Scandinavian countries, those family types contained a much larger fraction of the total poor. The explanation for the tendency towards larger households in New Zealand is probably one or more of the following:

oYoung adults remained in the parents' household for longer

oYoung adults were more likely to share (larger) flats with other young adults

oGrandparents were more likely to live with their children and grandchildren. 4.4 per cent of all New Zealand children lived in households with at least one person over the age of 60 , according to HES 2001. While this was higher than in Scandinavia (where the age threshold is also higher), it was not enough to account for much of the difference.

oDifferent age structure: in other words a larger proportion of middleaged people (with children), or more children per adult

However, looking at tables 3.6 the average size of households with elderly people in it was not much larger in New Zealand than in the other two countries, nor did New Zealand have fewer elderly people, so there must be other factors than the elderly population that explains the nearly double proportion of one-person 
households in Scandinavia. As a matter of fact, once it is taken into account that the overall average household is smaller in Sweden than in New Zealand, families with elderly people are on average larger in Sweden than in New Zealand ${ }^{18}$. The bigger households in New Zealand could potentially be a response to more widespread poverty or lower overall income, providing stronger incentive for people to exploit the economy of scale in larger households. That a so much larger proportion of the New Zealand poor live in large households would fit with this hypothesis. Cultural differences unrelated to poverty or income could of course also contribute to the difference in household size.

Table 3.6A Households' market income poverty rates by number of people over 60 in New Zealand

\begin{tabular}{|c|c|c|c|c|c|c|c|}
\hline 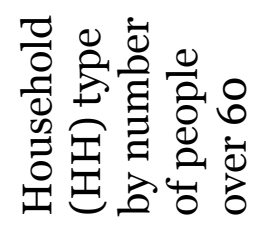 & 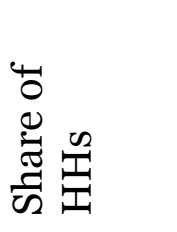 & 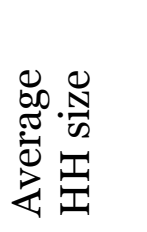 & 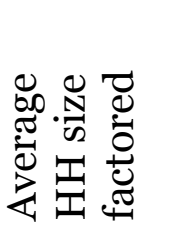 & 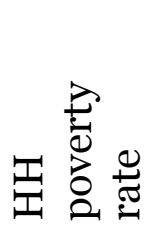 & 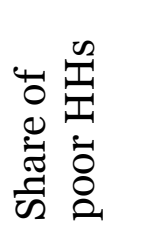 & 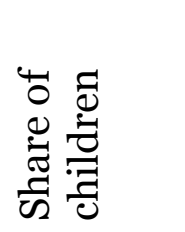 & 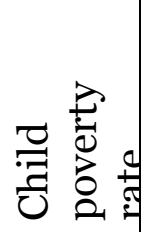 \\
\hline 0 & $70.3 \%$ & 2.98 & 1.12 & $19.6 \%$ & $42.2 \%$ & $95.6 \%$ & $29.1 \%$ \\
\hline 1 & $18.7 \%$ & 1.55 & 0.59 & $65.0 \%$ & $37.1 \%$ & $2.1 \%$ & $51.7 \%$ \\
\hline 2 or more & $11.0 \%$ & 2.41 & 0.91 & $61.7 \%$ & $20.7 \%$ & $2.3 \%$ & $46.8 \%$ \\
\hline Total or average & $1374 \quad 000$ & 2.65 & 1.00 & $32.7 \%$ & - & - & $29.9 \%$ \\
\hline 1 or more & $29.7 \%$ & 1.87 & 0.71 & $63.8 \%$ & $57.8 \%$ & $4.4 \%$ & $49.2 \%$ \\
\hline
\end{tabular}

(Source: HES 2001)

Table $3.6 \mathrm{~B}$ Households' market income poverty rates by number of people over 64in Norway

\begin{tabular}{|c|c|c|c|c|c|c|c|}
\hline 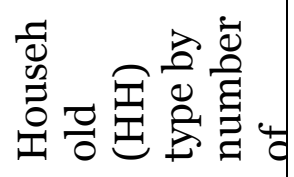 & 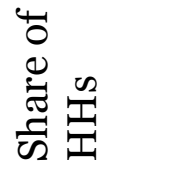 & 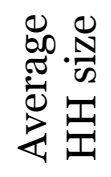 & 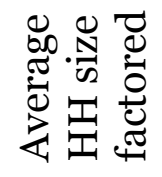 & 正总芯 & 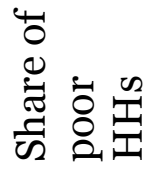 & 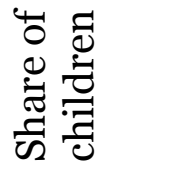 & 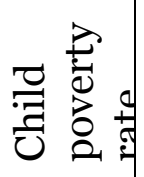 \\
\hline $\mathrm{O}$ & $74.7 \%$ & 2.36 & 1.10 & $24.4 \%$ & $47.2 \%$ & $99.5 \%$ & $16.3 \%$ \\
\hline 1 & $17.9 \%$ & 1.30 & 0.60 & $80.8 \%$ & $37.5 \%$ & $0.4 \%$ & $49.4 \%$ \\
\hline 2 or more & $7.3 \%$ & 2.09 & 0.97 & $80.9 \%$ & $15.4 \%$ & $0.1 \%$ & $\star$ \\
\hline Total or average & 2093000 & 2.15 & 1.00 & $38.7 \%$ & $100.0 \%$ & $\begin{array}{lll}1051 & 000 \\
\end{array}$ & $16.5 \%$ \\
\hline 1 or more & $25.3 \%$ & 1.53 & 0.71 & $80.8 \%$ & $52.8 \%$ & $0.5 \%$ & $36.2 \%$ \\
\hline
\end{tabular}

The third column shows the average size of this particular kind of household divided by the average household size. These figures are given to facilitate comparisons across the countries where the average differs.

${ }^{18}$ The average old household size is $71.83 \%$ of the overall average in Sweden, and $70.58 \%$ in New Zealand. 
Table 3.6C Household's market income poverty rates by number of people over 64in Sweden

\begin{tabular}{|c|c|c|c|c|c|c|c|}
\hline 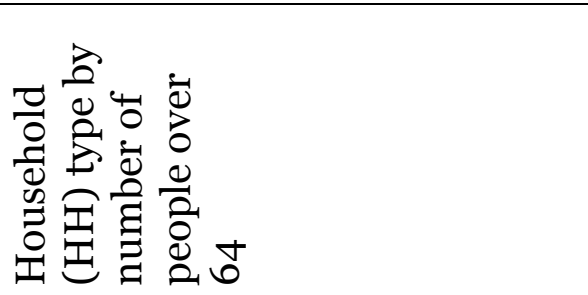 & 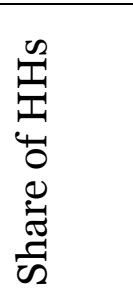 & 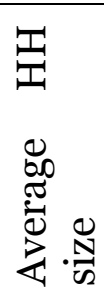 & 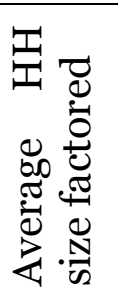 & 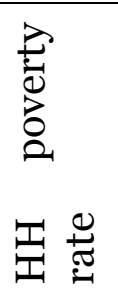 & 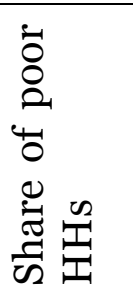 & 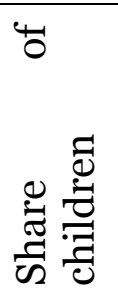 & 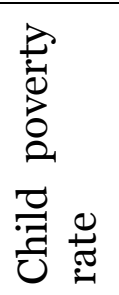 \\
\hline 0 & $73.7 \%$ & 2.21 & 1.10 & $24.7 \%$ & $45.6 \%$ & $99.6 \%$ & $20.0 \%$ \\
\hline 1 & $18.7 \%$ & 1.20 & 0.60 & $82.7 \%$ & $38.7 \%$ & $0.4 \%$ & $35.3 \%$ \\
\hline 2 or more & $7.7 \%$ & 2.03 & 1.01 & $81.7 \%$ & $15.7 \%$ & $0.0 \%$ & * \\
\hline Total in thousands, or average & 4327 & 2.01 & 1.00 & $39.9 \div$ & $100.0 \%$ & 1951 & $20.0 \div$ \\
\hline 1 or more & $26.3 \%$ & 1.44 & 0.72 & $82.4 \%$ & $54.4 \%$ & $0.4 \%$ & $36.4 \%$ \\
\hline
\end{tabular}

(Source: LIS 20OO)

* Insufficient data.

When looking at the proportion of the poor that are living in households with none, one or two or more persons over 60 or 64 the similarities across the countries are more striking than the differences, in particular since the slightly lower proportion of them living in non-old households in New Zealand may be at least partially explained by lower age category threshold. The (low) incidence of, and (high) poverty rate among children living in households with elderly people are also fairly homogenous across the countries.

As could be expected on the basis that wages and employability peaks at the middle of the career, there was a clear pattern showing that the closer the household head were to 45 (55 in Sweden), the less likely the household was to be poor, and the less deep was the poverty. The same trend holds for child poverty. This illustrates the importance of work. The larger share of children in New Zealand living in households where the head is younger than 29 or older than 65 is probably both a reflection of the higher fertility of young New Zealand women, as presumably children of young parents are more likely to live with grandparents who are older than 65. The larger households among young New Zealanders is partly a result of more children - out of the people living in households with head under 2418.1 per cent is under 18 in New Zealand, compared to 9.5 per cent and 6.6 per cent in Norway and Sweden, respectively. That said, a larger portion of young households in New Zealand seem to fare relatively well - although less so among those with children. Other studies may wish to explore this further by taking into account young people who are in education. 
Table 3.7 Market income poverty by head of household's age

\begin{tabular}{|c|c|c|c|c|c|c|c|c|}
\hline 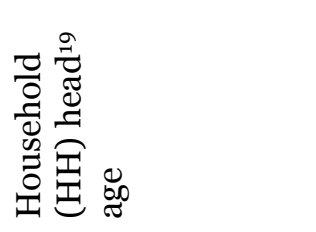 & 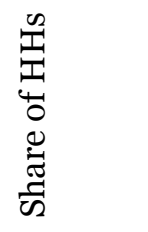 & 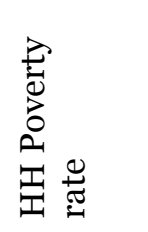 & 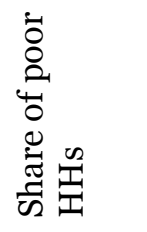 & 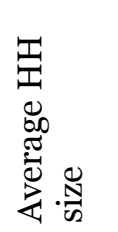 & 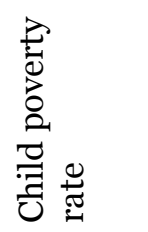 & 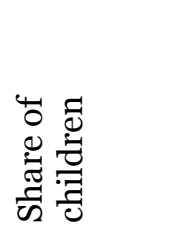 & 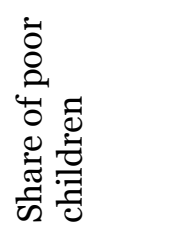 & 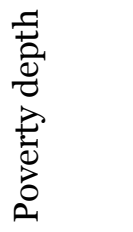 \\
\hline \multicolumn{9}{|c|}{$\begin{array}{l}\text { New Zealand } \\
\text { (Source: HES 200o/O1) }\end{array}$} \\
\hline $15-24$ & $5.5 \%$ & $34.5 \%$ & $5.8 \%$ & 2.6 & $55.1 \%$ & $4.0 \%$ & $7.3 \%$ & $63.6 \%$ \\
\hline $25-29$ & $7.5 \%$ & $26.9 \%$ & $6.2 \%$ & 2.9 & $48.7 \%$ & $10.5 \%$ & $17.2 \%$ & $65.9 \%$ \\
\hline 30-39 & $21.8 \%$ & $18.3 \%$ & $12.2 \%$ & 3.3 & $28.2 \frac{\circ}{0}$ & $45.7 \%$ & $43.1 \%$ & $66.9 \%$ \\
\hline $40-49$ & $20.8 \%$ & $16.2 \%$ & $10.3 \%$ & 3.2 & $22.5 \%$ & $30.6 \%$ & $23.0 \%$ & $59.5 \%$ \\
\hline 50-59 & $18.4 \%$ & $20.0 \%$ & $11.3 \%$ & 2.6 & $25.8 \%$ & $8.2 \%$ & $7.1 \%$ & $67.6 \%$ \\
\hline $60-64$ & $5.9 \%$ & $39.5 \%$ & $7.1 \%$ & 2.0 & $70.8 \%$ & $0.3 \%$ & $0.6 \%$ & $83.2 \%$ \\
\hline $65^{+}$ & $20.1 \%$ & $77.0 \div$ & $47.3 \%$ & 1.6 & $72.0 \%$ & $0.8 \%$ & $1.8 \%$ & $81.6 \%$ \\
\hline $\begin{array}{l}\text { Total in thousands } \\
\text { or average }\end{array}$ & 1374 & $32.7 \frac{\circ}{\circ}$ & 450 & 2.7 & $29.9 \div$ & 886 & 265000 & $74.1 \%$ \\
\hline \multicolumn{9}{|l|}{$\begin{array}{l}\text { Norway } \\
\text { (Source : LIS 2000) }\end{array}$} \\
\hline $15-24$ & $6.6 \%$ & $60.1 \%$ & $10.9 \%$ & 1.3 & $65.8 \%$ & $1.6 \%$ & $5.2 \%$ & $35.1 \%$ \\
\hline $25-29$ & $9.0 \%$ & $26.6 \%$ & $6.7 \%$ & 1.8 & $37.4 \%$ & $7.8 \%$ & $14.7 \%$ & $17.1 \%$ \\
\hline 30-39 & $19.5 \%$ & $18.0 \%$ & $9.7 \%$ & 2.7 & $23.2 \%$ & $43.0 \%$ & $52.7 \%$ & $11.4 \%$ \\
\hline $40-49$ & $18.3 \%$ & $13.4 \%$ & $6.8 \%$ & 3.0 & $11.3 \%$ & $37.9 \%$ & $21.6 \%$ & $8.8 \%$ \\
\hline 50-59 & $16.6 \%$ & $16.1 \%$ & $7.4 \%$ & 2.2 & $14.1 \%$ & $7.1 \%$ & $5.1 \%$ & $11.4 \%$ \\
\hline $60-64$ & $5.3 \%$ & $31.3 \%$ & $4.6 \%$ & 1.8 & $11.9 \%$ & $0.4 \%$ & $0.2 \%$ & $23.3 \%$ \\
\hline $65^{+}$ & $24.7 \%$ & $78.9 \%$ & $53.9 \%$ & 1.5 & $34.0 \%$ & $0.3 \%$ & $0.5 \%$ & $56.5 \%$ \\
\hline $\begin{array}{l}\text { Total in thousands } \\
\text { or average }\end{array}$ & 2093 & $36.2 \%$ & 756 & 2.2 & $19.8 \%$ & 1,051 & 208000 & $24.8 \%$ \\
\hline \multicolumn{9}{|l|}{$\begin{array}{l}\text { Sweden } \\
\text { (Source : LIS 2000) }\end{array}$} \\
\hline $15-24$ & $6.9 \%$ & $55.2 \%$ & $9.5 \%$ & 1.3 & $63.7 \%$ & $1.2 \%$ & $3.1 \%$ & $36.9 \%$ \\
\hline $25-29$ & $8.3 \%$ & $26.9 \%$ & $5.6 \%$ & 1.7 & $41.3 \%$ & $6.2 \%$ & $10.3 \%$ & $17.4 \%$ \\
\hline 30-39 & $18.1 \%$ & $22.6 \%$ & $10.3 \%$ & 2.6 & $29.4 \%$ & $44.2 \%$ & $52.6 \%$ & $15.2 \%$ \\
\hline $40-49$ & $17.6 \%$ & $18.4 \%$ & $8.1 \%$ & 2.7 & $17.7 \%$ & $38.9 \%$ & $27.8 \%$ & $13.4 \%$ \\
\hline 50-59 & $18.2 \%$ & $17.6 \%$ & $8.0 \%$ & 2.0 & $14.7 \%$ & $8.9 \%$ & $5.3 \%$ & $13.7 \%$ \\
\hline $60-64$ & $6.2 \%$ & $32.5 \%$ & $5.1 \%$ & 1.7 & $34.5 \%$ & $0.5 \%$ & $0.6 \%$ & $23.0 \%$ \\
\hline $65^{+}$ & $24.8 \%$ & $85.8 \%$ & $53.4 \%$ & 1.4 & $41.2 \%$ & $0.2 \%$ & $0.3 \%$ & $64.9 \%$ \\
\hline $\begin{array}{l}\text { Total in thousands } \\
\text { or average }\end{array}$ & 4327 & $39.9 \div$ & 1724 & 2.0 & $24.8 \frac{\circ}{0}$ & $\begin{array}{ll}1951 \\
\end{array}$ & 483000 & $29.1 \%$ \\
\hline
\end{tabular}

The LIS dataset for Norway and Sweden allows analyses of a few more variables, such as household head gender. Out of the 976 ooo households with only one adult in Norway, 55.9 per cent had a female adult. However, this relative balance

19 It is worth noting, but ultimately probably of small significance, that the method for determining who the household head is differs between the datasets. In Norway the head is always a male adult unless the only adult is female. It is not clear how the head is chosen in the datasets from Sweden and New Zealand, but certainly in Sweden the head can be a female even where a male adult is present in the household. 
evaporates when looking at children: out of the 160 ooo living with only one adult 85.2 per cent lived with a female. The total poverty rate was 64.7 per cent for households with a female adult and 42.0 per cent for those with a male adult. The child poverty rate was similar among the female headed households: 63.9 per cent, but significantly reduced in those headed by a male, to 28.8 per cent. Similarly, the child poverty gap ${ }^{20}$ were 40.0 per cent, and 20.7 per cent of the poverty line among the poor households for children living with a female and male adult, respectively. Out of the 2237000 households with only one adult in Sweden, in 55.9 per cent of the cases the adult were a female. Among these, 63.3 per cent were poor, compared to 44.3 per cent among the ones headed by a male. Out of the 372 ooo children living in single adult-households, 84.7 per cent lived in one led by a female. The child poverty rate here was 57.1 per cent, compared to 18.9 per cent among the male headed households. The child poverty gap was 39.5 per cent, and 13.3 per cent. If anything, it seems that for males, having children in the household is more strongly correlated with positive market incomes in Sweden; otherwise the differences between the two countries are small. For both the countries it is clear that children living with only one adult is worse off, and the majority, that live with a female, are particularly unlikely to be well off.

Another variable contained in the LIS-datasets only is marriage status of the household head divided into unmarried, married, divorced, widowed and separated. In the Swedish data the category for separated household heads are included in the divorced group.

${ }^{20}$ Note that child poverty gap is different from overall poverty gap, as it is weighted per child rather than per household. 
Table 3.8 A Norwegian market income poverty by marriage status of head of household

\begin{tabular}{|c|c|c|c|c|c|c|c|}
\hline 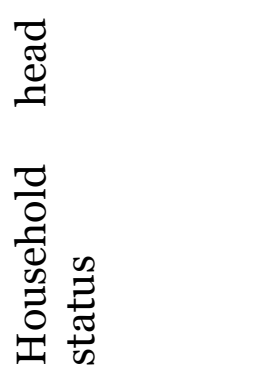 & 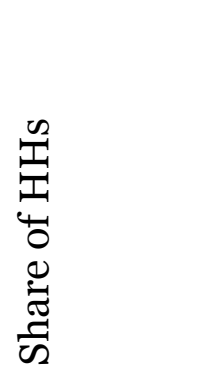 & \begin{tabular}{l}
0 \\
\multirow{0}{*}{} \\
0 \\
0 \\
0 \\
0 \\
0 \\
0
\end{tabular} & 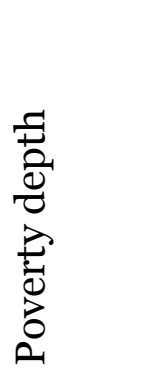 & 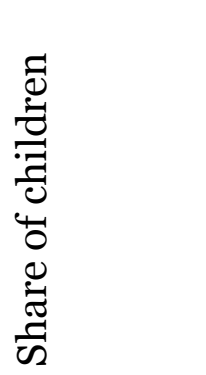 & 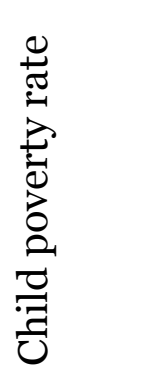 & 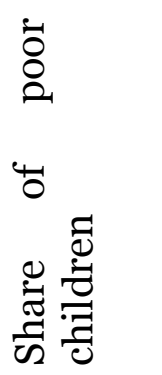 & $\begin{array}{l}\stackrel{D}{N} \\
\stackrel{\sim}{\infty} \\
\stackrel{I}{I}\end{array}$ \\
\hline Unmarried & $31.8 \%$ & $35.5 \%$ & $23.0 \%$ & $22.1 \%$ & $25.7 \%$ & $34.4 \%$ & 1.6 \\
\hline Married & $41.2 \%$ & $22.9 \%$ & $14.1 \%$ & $65.0 \%$ & $8.9 \%$ & $35.1 \%$ & 3.0 \\
\hline Divorced & $12.0 \%$ & $38.7 \%$ & $28.8 \%$ & $9.0 \%$ & $35.1 \%$ & $19.2 \%$ & 1.7 \\
\hline Widowed & $12.6 \%$ & $79.2 \%$ & $60.2 \%$ & $0.9 \%$ & $53.2 \%$ & $2.8 \%$ & 1.2 \\
\hline Separated & $2.4 \%$ & $35.1 \%$ & $25.1 \%$ & $3.0 \%$ & $46.7 \%$ & $8.5 \%$ & 1.9 \\
\hline $\begin{array}{ll}\text { Total } & \text { or } \\
\text { average } & \end{array}$ & 2093000 & $36.2 \%$ & $24.8 \%$ & 1052000 & $16.5 \%$ & 173000 & 2.6 \\
\hline
\end{tabular}

(Source: LIS 2000)

The child poverty figures in the table provides more evidence indicating that the number of income earners was the most important factor in predicting child poverty, in that households where the adults are married had, by far the lowest child poverty rate, and also lower poverty depth. That households where the head is divorced, widowed or separated had higher child poverty rate probably reflects that these family changes (divorces/separations and deaths of adults) are what DiPrete and McManus (2000) calls negative trigger events, even though the overall poverty rate for unmarried household heads was similar to that of the households that have experienced divorce or separation. This could reflect that households with children are more vulnerable to such triggers. 
Table 3.8 B Swedish market income poverty by marriage status of head of household

\begin{tabular}{|c|c|c|c|c|c|c|c|}
\hline 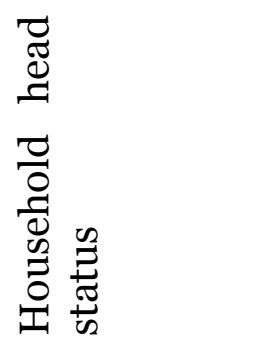 & 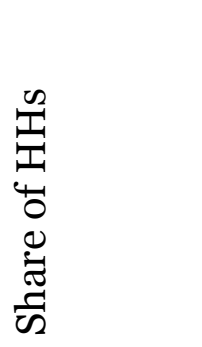 & 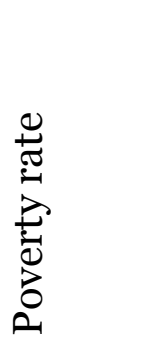 & 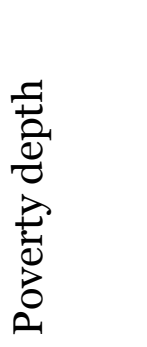 & 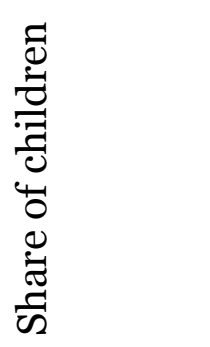 & 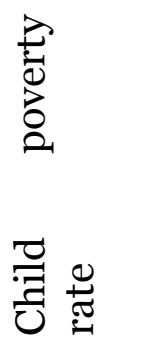 & 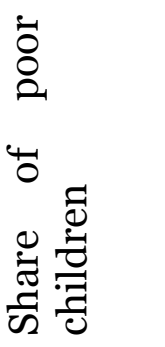 & 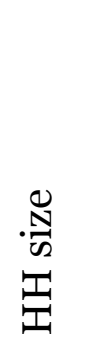 \\
\hline Unmarried & $37.1 \%$ & $35.6 \%$ & $25.2 \%$ & $28.8 \%$ & $24.6 \%$ & $35.3 \%$ & 1.6 \\
\hline Married & $36.4 \%$ & $28.1 \%$ & $18.9 \%$ & $58.1 \%$ & $13.9 \%$ & $40.3 \%$ & 2.9 \\
\hline Divorced & $15.2 \%$ & $45.2 \%$ & $34.5 \%$ & $12.4 \%$ & $38.0 \%$ & $23.5 \%$ & 1.6 \\
\hline Widowed & $11.4 \%$ & $84.1 \%$ & $67.3 \%$ & $0.8 \%$ & $22.3 \%$ & $0.9 \%$ & 1.1 \\
\hline $\begin{array}{ll}\text { Total } & \text { or } \\
\text { average } & \end{array}$ & 4327000 & $39.9 \%$ & $29.1 \%$ & 1951000 & $20.0 \%$ & 390000 & 2.0 \\
\hline
\end{tabular}

(Source: LIS 200O)

The differences between the countries are modest, and the lower child poverty rate in widowed households may not be significant, considering the small number of cases. The marriage status is a stronger predictor of the probability of poverty in Norway than in Sweden ${ }^{21}$.

\subsection{Return to ethnicity; the effect on family structure, age and poverty}

So far, it has been assumed that households with different ethnic or immigrant status are comparable in terms of family type and age. This section will relax this assumption, and show how that changes the picture. This section nonetheless comes with the same caveat as section 3.2, namely that ethnicity and migration really are severe simplifications, and particularly the 'other' ethnic category in New Zealand and the immigrant category in the Scandinavian countries contain extremely heterogeneous cases. With this in mind the findings remain interesting.

The 2001 HES dataset for New Zealand does not allow a direct analysis of poverty levels in household types of certain ethnicities. However, it does give the number of poor/non-poor individuals, children and households by household head ethnicity. Based on this child poverty rates are calculated per ethnicity, as well as average household size in the various ethnicities.

${ }^{21}$ Many factors such as age and fertility structures could account for this, so it is beyond the scope of this thesis to account for why this is the case. 
Table 3.9 A Market income poverty by ethnic affiliation of household head in New Zealand

\begin{tabular}{|c|c|c|c|c|c|c|c|}
\hline 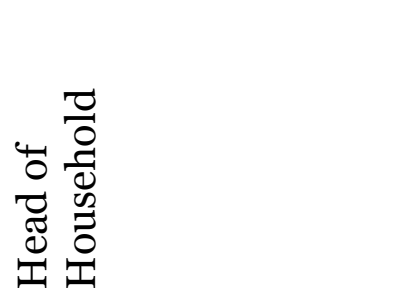 & 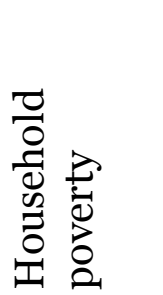 & 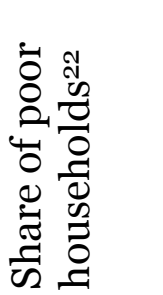 & $\begin{array}{l}0 \\
0 \\
0 \\
0 \\
0 \\
0 \\
0 \\
0 \\
0 \\
0\end{array}$ & 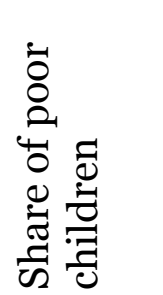 & 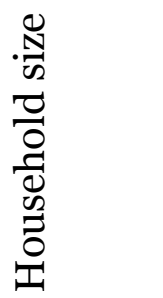 & 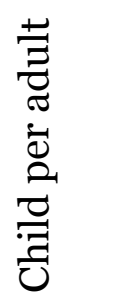 & 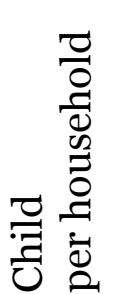 \\
\hline European & $31.0 \%$ & $75.8 \%$ & $22.8 \%$ & $52.1 \%$ & 2.5 & 0.3 & 0.6 \\
\hline Māori & $44.1 \%$ & $15.1 \%$ & $47.2 \%$ & $26.3 \%$ & 2.9 & 0.5 & 1.0 \\
\hline Pacific people & $45.4 \%$ & $4.9 \%$ & $51.7 \%$ & $13.2 \%$ & 3.9 & 0.6 & 1.4 \\
\hline Other (Notably Asian) & $27.1 \%$ & $4.3 \%$ & $34.4 \%$ & $8.5 \%$ & 3.5 & 0.4 & 0.9 \\
\hline Total / Average & $32.7 \%$ & $450 \quad 000$ & $29.9 \%$ & 265000 & 2.7 & 0.3 & 0.6 \\
\hline
\end{tabular}

Clearly, children in the 'other' category were much worse off than their parents, especially when compared to children in households where the head identified as having a European identity. The larger households in the Pacific people and 'other' groups could reflect that those groups are more likely to be immigrant (see Table 3.2), and that this led to larger households, possibly because of age structure. While this dataset cannot determine how much of the effect was caused by larger household size and higher number of children, it seems that in the poorer ethnic groups, children are particularly likely to be poor. The table below provides the almost equivalent figures for households where the head or spouse has immigrant background in Norway and Sweden.

Table 3.9 B Market income poverty in Norway by immigrant status

\begin{tabular}{|c|c|c|c|c|c|c|c|}
\hline 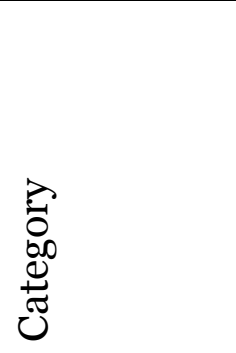 & 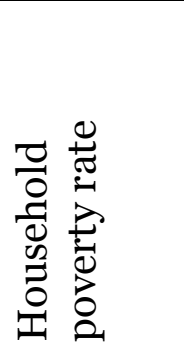 & 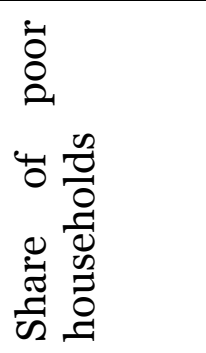 & 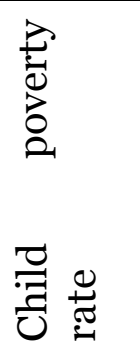 & 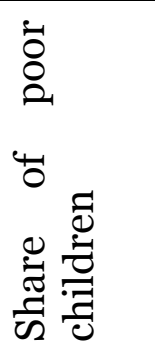 & $\begin{array}{l}0 \\
. \mathbb{N} \\
0 \\
0 \\
0 \\
0 \\
0 \\
0 \\
0 \\
0 \\
0 \\
0\end{array}$ & 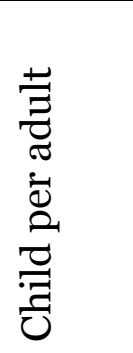 & 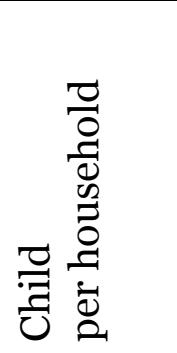 \\
\hline $\begin{array}{l}\text { Immigrant } \\
\text { background }\end{array}$ & $36.0 \%$ & $7.9 \%$ & $28.9 \%$ & $20.8 \%$ & 2.2 & 0.4 & 0.8 \\
\hline $\begin{array}{l}\text { Total } \\
\text { households }\end{array}$ & $36.2 \%$ & $100 \%$ & $16.5 \%$ & $100 \%$ & 2.5 & 0.3 & 0.5 \\
\hline
\end{tabular}

${ }^{22}$ Note that the in HES dataset the ethnic affiliation of household heads does not correspond to the census data on ethnic affiliation of the total population. In the HES dataset $80.1 \%$ of total household has a head with that identifies as European ethnicity, 11.2\%, 3.5\% and 5.2\% has Māori, Pacific Island and 'Other', respectively. 
Table 3.9 C Market income poverty in Sweden by immigrant status

\begin{tabular}{|c|c|c|c|c|c|c|c|}
\hline 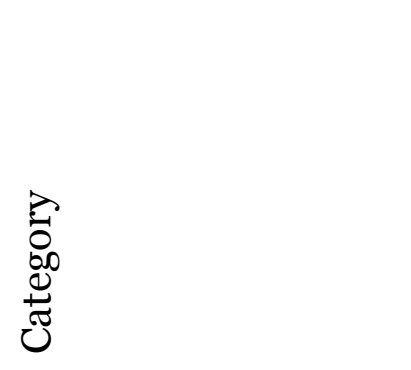 & 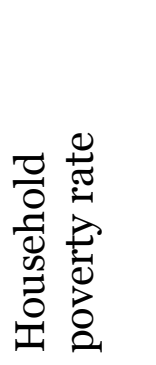 & 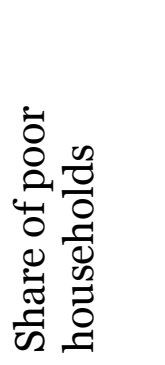 & 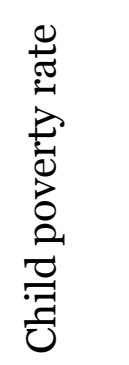 & 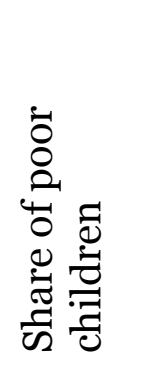 & 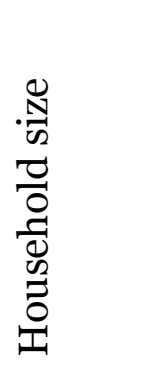 & 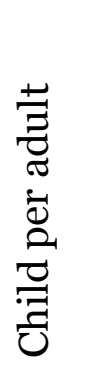 & 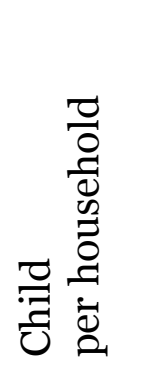 \\
\hline Immigrant background & $45.4 \%$ & $16.8 \%$ & $32.6 \%$ & $38.0 \%$ & 2.3 & 0.4 & 0.7 \\
\hline Total households & $39.9 \%$ & $100 \%$ & $20.0 \%$ & $100 \%$ & 2.0 & 0.3 & 0.5 \\
\hline
\end{tabular}

Looking closer at the data by including age, as is demonstrated in tables 3.10 below it becomes clear that the lower poverty rate among households with immigrant background in Norway was purely due to a different age composition of the immigrant population. When comparing the poverty rate of immigrant and total population by the age of the household head, the immigrant group had a higher poverty rate than the total in every age group, except the one where the head is older than 64 years old. In this category the poverty rate was 74.8 per cent among those with immigrant background versus 78.9 per cent for the total households. The age group where the poverty rate among immigrants is most different from the total (measured in percentage points) was found in the households where the head is 2529 years old: Households where head or spouse had immigrant background has a poverty rate of 40.6 per cent, compared to 26.6 per cent among the total.

As the household head age is increased, the outcome for immigrants relative to the total steadily improved. In Sweden the situation was similar, even though the total poverty rate is much higher among the immigrant population relative to the total. This difference from Norway could be explained by the fact that the age composition of immigrants in Sweden was more similar to that of the locally born population. 24.8 per cent of the total households had a head over 64 years, compared to only 14.5 per cent of the immigrant households. It would in other words be consistent with the data to assume that the lower poverty rate among immigrants among the over 64 is purely because they, on average are younger, even though the data do not indicate this. For the population under 65 , the group where the poverty rate difference (between immigrant households and the total) in percentage points is least is in the households where the head is between 25 and 29 years old. In that 
group of households those headed by a person with immigrant background, had a poverty rate of 33.5 per cent, compared to 26.9 per cent in the total group.

The largest percentage point difference is found in the households where the head is in his/her thirties, where immigrant households has a poverty rate of 36.7 per cent, compared to 22.6 per cent in the total number of households. This could reflect that immigrants in this age group are particularly likely to have recently arrived, but possibly also that immigrants tend to have more children, which leads to higher risk of poverty.

Table 3.10A Household (HH) poverty, by age of household head (HHH), immigrant status, Norway

\begin{tabular}{|c|c|c|c|c|c|c|}
\hline 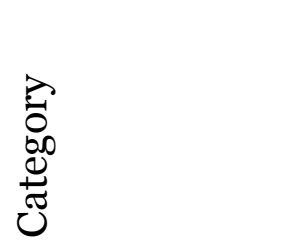 & 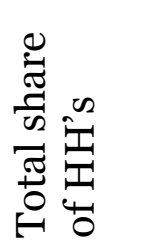 & 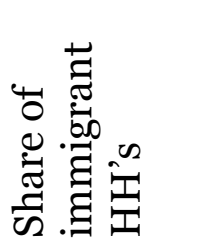 & 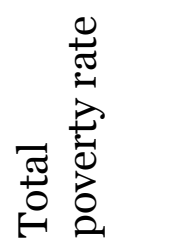 & 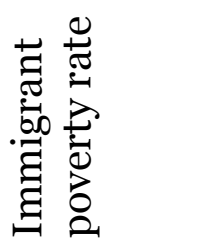 & 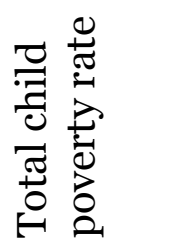 & 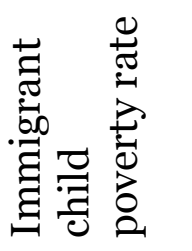 \\
\hline HHH age $15-24$ & $6.6 \%$ & $5.7 \%$ & $60.1 \%$ & $67.6 \%$ & $61.9 \%$ & * \\
\hline HHH age $25-29$ & $9.0 \%$ & $10.2 \%$ & $26.6 \%$ & $40.6 \%$ & $31.1 \%$ & $42.5 \%$ \\
\hline HHH age 30-39 & $19.5 \%$ & $29.1 \%$ & $18.0 \%$ & $30.3 \%$ & $19.3 \%$ & $31.0 \%$ \\
\hline HHH age 40-49 & $18.3 \%$ & $20.5 \%$ & $13.4 \%$ & $23.2 \%$ & $9.0 \%$ & $24.3 \%$ \\
\hline HHH age $50-59$ & $16.6 \%$ & $17.5 \%$ & $16.1 \%$ & $20.1 \%$ & $11.6 \%$ & $19.8 \%$ \\
\hline HHH age 6o-64 & $5.3 \%$ & $4.6 \%$ & $31.3 \%$ & $35.0 \%$ & $11.9 \%$ & $21.0 \%$ \\
\hline HHH age $65^{+}$ & $24.7 \%$ & $12.6 \%$ & $78.9 \%$ & $74.8 \%$ & $40.0 \%$ & * \\
\hline
\end{tabular}

(Source: LIS 2000; ${ }^{*}=$ Insufficient data)

Table 3.10 $B$ Household poverty, by age of household head, immigrant status, Sweden

\begin{tabular}{|c|c|c|c|c|c|c|}
\hline \begin{tabular}{l}
0 \\
0 \\
$\infty$ \\
\multirow{0}{*}{} \\
0 \\
0
\end{tabular} & 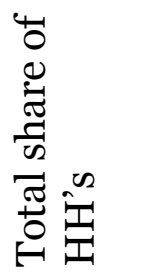 & 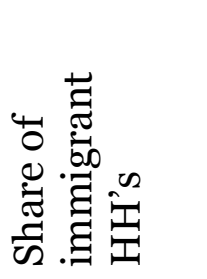 & 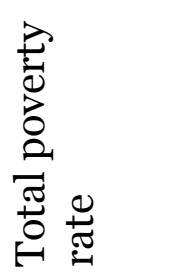 & 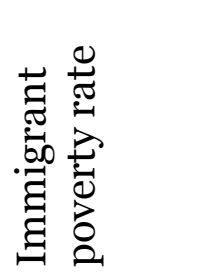 & 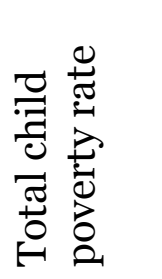 & 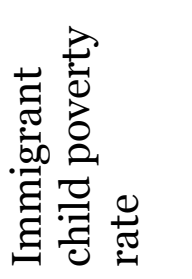 \\
\hline HHH age $15-24$ & $6.9 \%$ & $4.7 \%$ & $55.2 \%$ & $62.4 \%$ & $59.3 \%$ & $61.9 \%$ \\
\hline HHH age 25-29 & $8.3 \%$ & $7.9 \%$ & $26.9 \%$ & $33.5 \%$ & $36.6 \%$ & $33.0 \%$ \\
\hline HHH age 30-39 & $18.1 \%$ & $22.6 \%$ & $22.6 \%$ & $36.7 \%$ & $23.2 \%$ & $40.9 \%$ \\
\hline HHH age $40-49$ & $17.6 \%$ & $23.5 \%$ & $18.4 \%$ & $29.9 \%$ & $14.0 \%$ & $24.8 \%$ \\
\hline HHH age 50-59 & $18.2 \%$ & $19.2 \%$ & $17.6 \%$ & $28.6 \%$ & $12.8 \%$ & $22.8 \%$ \\
\hline HHH age $60-64$ & $6.2 \%$ & $7.4 \%$ & $32.5 \%$ & $43.5 \%$ & $31.6 \%$ & $34.1 \%$ \\
\hline HHH age $65^{+}$ & $24.8 \%$ & $14.5 \%$ & $85.8 \%$ & $83.2 \%$ & $41.2 \%$ & $66.9 \%$ \\
\hline
\end{tabular}

(Source: LIS 2OOO) 
A regression analysis confirmed that immigrants in Norway had higher poverty rate than the native population when demographic structure was controlled for, even though the average poverty rate in two groups were very similar. In fact, when comparing the two countries the difference in terms of immigrant market incomes, the difference seems to be less when other factors are controlled for. It is unfortunate that there is not sufficient data to run this model in New Zealand. 


\subsection{Education}

Unfortunately, the New Zealand HES dataset does not contain data on education levels of parents or adults. The variable is so important that it is still worthwhile to look at the effect of education in the Scandinavian countries, as the LIS dataset does contain education data.

While saying that education affects wages and income may be merely stating the obvious, there are competing hypotheses to explain exactly how this happens: most logically that education is an investment in human capital that increases productivity. However, the decision to undertake a particular kind of education may also be motivated by the wish to create a signalling effect, implying that higher productivity is the result of innate, rather than acquired ability (Boarini and Strauss, 2007:6-7). Education decisions may both cause and be correlated with non-pecuniary outcomes such as social prestige, better health, lower propensity to commit crimes, etc. (Grossman, 2005). Schooling decisions may also depend on the taste for schooling, cost, access to funds and innate ability; it need not always be an optimising investment decision. There is a large pool of literature exploring the socalled internal rates of return (Boarini and Strauss, 2007) to education, i.e. the effect of education on the overall income distribution. In this economics dominated literature other factors such as ethnicity, age, type of education, gender, etc. are often taken into account. The focus is on individual's income, meaning that the challenges involved in comparing different families are avoided. These two differences (i.e. the focus on the entire income distribution, not just the lower end, and the focus on individual conditions rather than households) are crucial, but in lack of detailed studies of the effect of education on poverty, the research done in the area highlight the importance of education and illustrates how education interact with other variables. This section will start by looking at the private rate of return in all three countries, and then look at the effect of adult's education on poverty in households in Norway and Sweden using the LIS dataset.

Boarini and Strauss (2007:8) decomposes the benefit of schooling into three components: the wage premium, i.e. the increase in (net) wage that higher education yields while keeping the employment probability constant; the employability premium, i.e. the increased probability of being employed holding the wage fixed that follows from higher education; and finally the pension premium, i.e. 
the higher retirement benefit that follows from better outcomes in both the two previous components. Blöndal et al (2002:6) highlights that the labour market connection, or employability premium can be measured both as lower unemployment and higher participation rates, often two separate statistics. Boarini and Strauss (2007:41) also control for labour market experience. Looking at 21 different OECD countries'3they find that five countries has a lower wage premia for tertiary education among men than Sweden, and only two has a lower wage premia for women. They suggest that the strong dispersion of wage premia reflects "country specific wage productivity differences between tertiary and upper secondary degree holders, but also other factors such as different scarcity rents on skilled labour and the degree of labour market regulation" (Boarini and Strauss, 2007:13).

With regards to the experience premia, on the other hand, one of the highest rates is found in Sweden, both for men and women. Here they also find a clear trend of higher premia for men than women. No universal trend exists either way in education premia. The marginal effect of tertiary education on employment probability is on average higher for women than for men in the 21 countries examined, and particularly so in Sweden. Only Finnish and Hungarian women raise their probability of being employed more per year of tertiary education than Swedish women. The effect on Swedish men is slightly below average and median. When taking multiple factors into account, including wage premium, employment probability, pension premium, taxes, as well as direct and indirect costs of education it varies across the countries whether men or women has higher return to education, but on average men has slightly higher return. For all countries the return is significant and positive. Sweden is among the countries where the return is relatively low (Boarini and Strauss, 2007:50).

According to Blöndal, et al (2002:9) in a cross-country study, education does not only provide an earnings advantage when entering the labour market, this effect increases with time spent in the labour market. This is important in a perspective where the focus is on households and children, and also in a gender perspective. The study also finds that not only are individuals with higher education less likely to be unemployed, they also tend to have a longer active working life (Blöndal, et al., 2002:15).

23 Unfortunately, Norway and New Zealand are not included. 
Figure 3.4 Upper secondary and tertiary educational attainment percentage by age group and gender in New Zealand, Norway ${ }^{24}$ and Sweden

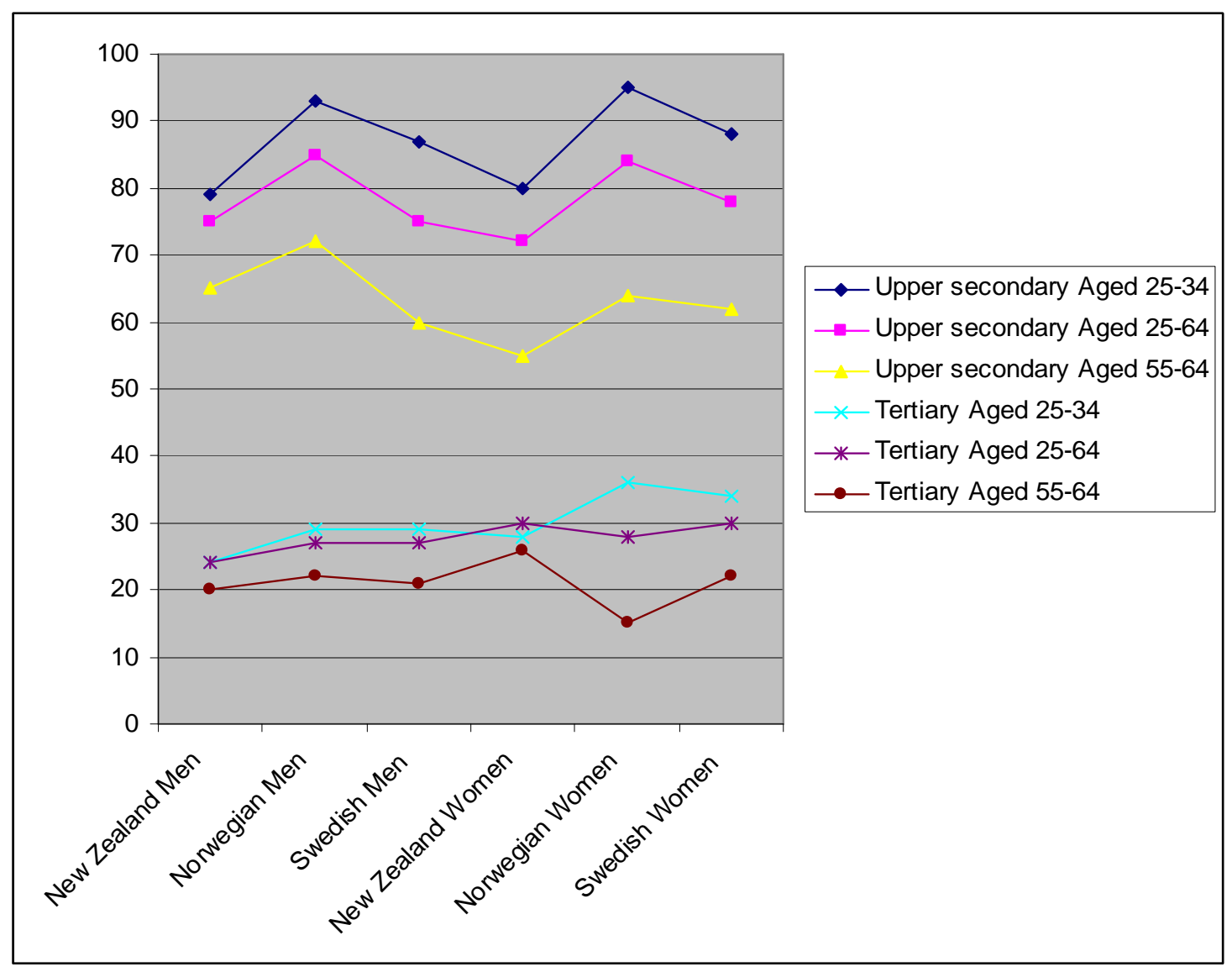

(Source: Blöndal, et al., 2002:40)

The figure shows a few clear trends. In upper secondary education attainment Norway has the highest rate for both genders and all age groups. This could, however be due to different categorisation of the school systems. The Swedes has higher than or similar rates to New Zealanders, except for men in the 55-64 category. For tertiary education attainment, the most obvious finding is that Norwegian women's rate is much higher for the 25-35 group than the 55-64 group. The New Zealand women category is the only one where the attainment rate is noticeably lower among the young group than the average. Clearly the higher attainment among the younger groups is an illustration of the increasing education level, which is particularly apparent among women, and more so in the Scandinavian countries than in New Zealand.

24 Year of reference 1998 
Maani (2004) investigates the relationship between ethnicity, education and relative income in New Zealand in the 1986 to 1996 period, with a particular focus in explaining the deteriorating income levels of Māori. She argues that educational attainment is an important contributor to the income gap between Māori and the white/European population. She concludes that "while there are significant differences in the educational attainment of Māori and non-Māori groups, once educational attainment is controlled for, much of the income gap disappears, particularly in 1996 [compared to 1986].” (Maani, 2004:123). When running regression analyses where income is the dependent variable and the analyses of the different ethnic groups are run separately, she finds that even though the interception point was lower among Māori, the return to education was higher. The income gap was in other words negatively correlated with income: among groups with high education attainment, Māori had similar income to non-Māori. While Māori with low education still was significantly less paid than non-Māori most of the total difference was due to Māorion average being younger and having lower education attainment. This suggests that overcoming the tendency of intergenerational transfer of human capital attainment plays an important role in closing the income gap between ethnic groups. As Machin (2006:7) puts it: "education [...] offer[s] a route where people can escape from disadvantaged family backgrounds and climb the social ladder." For this to become a reality however, the degree to which family background predicts education attainment must be reduced as well. Based on data from Third International Mathematics and Science Study (TIMSS) Machin (2006:11) finds that in a ranking of 54 countries, New Zealand has the $14^{\text {th }}$ strongest correlation between family background and students' test score, with Sweden and Norway a bit behind on number 19 and 23, respectively. This may or may not be an illustration of how ethnicity is more important in New Zealand in the sense that ethnic minority groups are bigger and poorer.

Further research could also look into how such findings are received by the public. Certainly in the Norwegian public debate the correlation between social background and education/test results are seen as an important factor when evaluating the school system. 
Table 3.11A Household (HH) and child poverty in Norway, by highest educated adult in household

\begin{tabular}{|c|c|c|c|c|c|c|c|}
\hline & 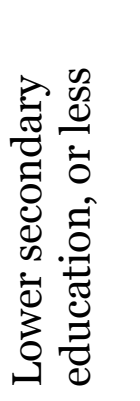 & 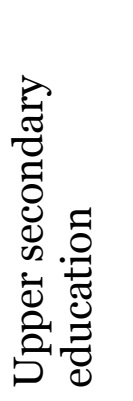 & 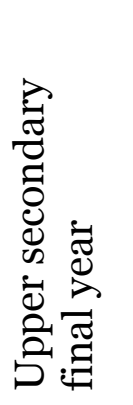 & 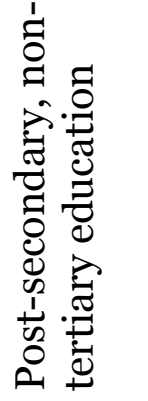 & 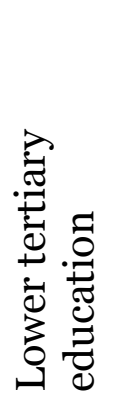 & 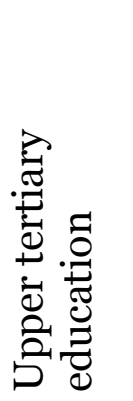 & 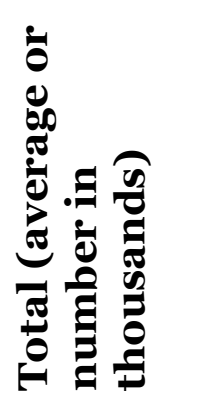 \\
\hline $\begin{array}{l}\text { Share of total } \\
\mathrm{HHs}\end{array}$ & $18.7 \%$ & $26.9 \%$ & $23.5 \%$ & $2.8 \%$ & $21.4 \%$ & $6.7 \%$ & $2,058,534$ \\
\hline $\begin{array}{l}\text { Share of poor } \\
\text { HHs }\end{array}$ & $38.6 \%$ & $32.7 \%$ & $15.6 \%$ & $1.4 \%$ & $10.3 \%$ & $1.4 \%$ & 735,849 \\
\hline $\begin{array}{l}\text { HH poverty } \\
\text { rate }\end{array}$ & $73.8 \%$ & $43.5 \%$ & $23.8 \%$ & $18.0 \%$ & $17.2 \%$ & $7.5 \frac{\circ}{\circ}$ & $35.7 \%$ \\
\hline $\begin{array}{l}\text { Share of total } \\
\text { children }\end{array}$ & $3.4 \%$ & $20.8 \%$ & $30.8 \%$ & $4.2 \%$ & $29.9 \%$ & $10.9 \%$ & $1,032,922$ \\
\hline $\begin{array}{l}\text { Share of poor } \\
\text { children }\end{array}$ & $11.5 \%$ & $45.1 \%$ & $27.5 \%$ & $2.4 \%$ & $12.2 \%$ & $1.4 \%$ & 161,747 \\
\hline $\begin{array}{l}\text { Child poverty } \\
\text { rate }\end{array}$ & $52.3 \frac{0}{0}$ & $33.9 \%$ & $14.0 \%$ & $8.9 \div$ & $6.4 \%$ & $2.0 \%$ & $15.7 \%$ \\
\hline $\begin{array}{l}\text { Average } \\
\text { number of } \\
\text { children per } \\
\text { household }\end{array}$ & 0.1 & 0.4 & 0.7 & 0.7 & 0.7 & 0.8 & 0.5 \\
\hline
\end{tabular}

Table 3.11 B Household (HH) and child poverty in Sweden, by highest educated adult in household

\begin{tabular}{|c|c|c|c|c|c|c|c|c|}
\hline & 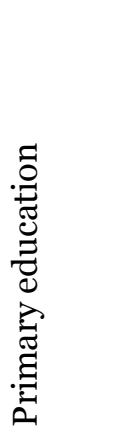 & 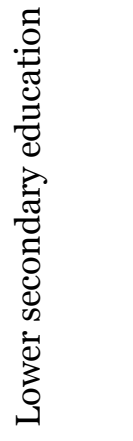 & 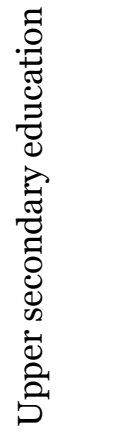 & 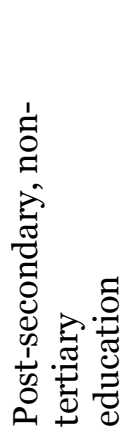 & 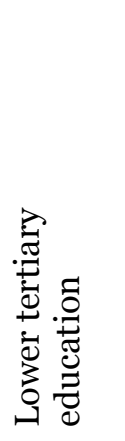 & 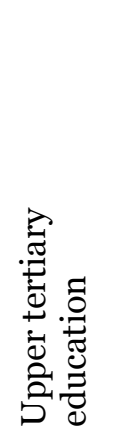 & 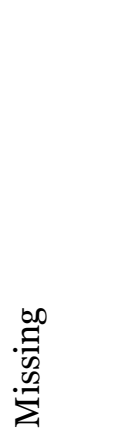 & 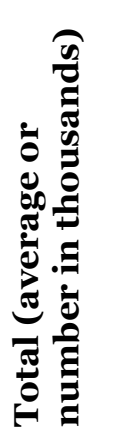 \\
\hline Share of total $\mathrm{HHs}$ & $9.4 \%$ & $7.2 \%$ & $41.1 \%$ & $5.2 \%$ & $23.3 \%$ & $0.9 \%$ & $12.8 \%$ & 4,294 \\
\hline Share of poor HHs & $16.2 \%$ & $8.9 \%$ & $30.7 \%$ & $4.3 \%$ & $9.5 \%$ & $0.1 \%$ & $30.2 \%$ & 1,699 \\
\hline HH poverty rate & $68.3 \%$ & $48.7 \%$ & $29.6 \%$ & $32.7 \div$ & $16.1 \%$ & $5.3 \%$ & $93.2 \%$ & $39.6 \%$ \\
\hline $\begin{array}{l}\text { Share of total } \\
\text { children }\end{array}$ & $1.4 \%$ & $6.5 \%$ & $49.9 \%$ & $6.6 \%$ & $34.3 \%$ & $1.3 \%$ & - & 1,932 \\
\hline $\begin{array}{ll}\begin{array}{l}\text { Share of poor } \\
\text { children }\end{array} & \\
\end{array}$ & $5.5 \%$ & $17.8 \%$ & $54.1 \%$ & $5.2 \%$ & $17.1 \%$ & $0.3 \%$ & - & 376 \\
\hline Child poverty rate & $74.7 \%$ & $53.5 \%$ & $21.1 \%$ & $15.2 \%$ & $9.7 \%$ & $4.2 \%$ & - & $19.5 \%$ \\
\hline $\begin{array}{l}\text { Average number of } \\
\text { children per } \\
\text { household }\end{array}$ & 0.1 & 0.4 & 0.5 & 0.6 & 0.7 & 0.6 & 0.0 & 0.5 \\
\hline
\end{tabular}


The tables above show that lack of education is a strong explanatory factor of market poverty, for both households and children. Clearly, the households with only lower secondary education has a very high risk of being poor, and the trend is consistent - the higher education the lower probability of being poor. 


\subsection{Employment and benefit status}

As alluded to in section 3.5 on education, there are two mechanisms that makes the labour market create heterogeneity: differences in wage or pay, and differences in employment.

Employment is obviously the single most direct and important predictor of market income, almost to the extent that explaining market income with employment status is little more than a circular argument. However, employment status is also a variable that is likely to change over relatively short term (compared to e.g. education), and over the lifetime of most individuals, and employment status will be predicted by many of the variables discussed above. Again, the variables used in New Zealand and Scandinavia do not correspond fully. The LIS dataset for Norway and Sweden includes data for head and spouse of household on disability status, whether employment is largest income source and alternatively what kind of benefit is received. The New Zealand HES dataset gives numbers, poverty rate and poverty gap of children adults and households separated into those where the majority income is from benefits, some income from benefits, and those that has no benefit income and one, two, or three adults. In other words, it does not tell whether the individuals have a work income, only whether benefits are received. Benefit status will be used as a proxy for employment status.

Table 3.12A New Zealand market income poverty by benefit status

\begin{tabular}{|l|l|l|l|l|l|}
\hline & $\begin{array}{l}\text { Share of total } \\
\text { households }\end{array}$ & $\begin{array}{l}\text { Household } \\
\text { poverty rate }\end{array}$ & $\begin{array}{l}\text { Share of } \\
\text { children }\end{array}$ & $\begin{array}{l}\text { Child } \\
\text { poverty rate }\end{array}$ & $\begin{array}{l}\text { Poverty } \\
\text { gap }\end{array}$ \\
\hline $\begin{array}{l}\text { Majority income } \\
\text { from benefits }\end{array}$ & $18.8 \%$ & $100.0 \%$ & $12.5 \%$ & $100.0 \%$ & $93.8 \%$ \\
\hline $\begin{array}{l}\text { Some income from } \\
\text { benefits }\end{array}$ & $15.1 \%$ & $57.6 \%$ & $12.1 \%$ & $63.1 \%$ & $52.8 \%$ \\
\hline $\begin{array}{l}\mathbf{1} \text { adult no benefit } \\
\text { income }\end{array}$ & $22.4 \%$ & $16.9 \%$ & $23.6 \%$ & $31.1 \%$ & $41.7 \%$ \\
\hline $\begin{array}{l}\mathbf{2} \text { adult no benefit } \\
\text { income }\end{array}$ & $32.3 \%$ & $3.7 \%$ & $42.9 \%$ & $5.6 \%$ & $29.2 \%$ \\
\hline $\begin{array}{l}3 \text { adult no benefit } \\
\text { income }\end{array}$ & $11.4 \%$ & $2.1 \%$ & $9.0 \%$ & $1.3 \%$ & $34.3 \%$ \\
\hline Total/ average & $\mathbf{1 , 3 7 4 , 0 0 0}$ & $\mathbf{3 2 . 7 \%}$ & $\mathbf{8 8 6 , 0 0 0}$ & $\mathbf{2 9 . 9} \%$ & $\mathbf{7 4 . 1 \%}$ \\
\hline
\end{tabular}


Table 3.12B Norwegian market income poverty by benefit status

\begin{tabular}{|l|l|l|l|l|l|}
\hline & $\begin{array}{l}\text { Share of total } \\
\text { households }\end{array}$ & $\begin{array}{l}\text { Household } \\
\text { poverty rate }\end{array}$ & $\begin{array}{l}\text { Share of } \\
\text { children }\end{array}$ & $\begin{array}{l}\text { Child } \\
\text { poverty } \\
\text { rate }\end{array}$ & $\begin{array}{l}\text { Poverty } \\
\text { gap }\end{array}$ \\
\hline $\begin{array}{l}\text { Main income from } \\
\text { benefit }\end{array}$ & $36.0 \%$ & $87.9 \%$ & $8.6 \%$ & $94.2 \%$ & $65.1 \%$ \\
\hline $\begin{array}{l}\text { Head or spouse main } \\
\text { income from } \\
\text { employment }\end{array}$ & $36.8 \%$ & $11.9 \%$ & $32.2 \%$ & $24.2 \%$ & $3.5 \%$ \\
$\begin{array}{l}\text { Head and spouse main } \\
\text { income from } \\
\text { employment }\end{array}$ & $27.2 \%$ & $0.5 \%$ & $59.3 \%$ & $1.0 \%$ & $0.1 \%$ \\
\hline \begin{tabular}{l} 
Total/ average \\
\hline
\end{tabular} & $\mathbf{2 , 0 9 3 , 0 0 0}$ & $\mathbf{3 6 . 1 \%}$ & $\mathbf{1 , 0 5 1 , 0 0 0}$ & $\mathbf{1 6 . 4 \%}$ & $\mathbf{2 4 . 8 \%}$ \\
\hline
\end{tabular}

Table 3.12C Swedish market income poverty by benefit status

\begin{tabular}{|l|l|l|l|l|l|}
\hline & $\begin{array}{l}\text { Share of total } \\
\text { households }\end{array}$ & $\begin{array}{l}\text { Household } \\
\text { poverty rate }\end{array}$ & $\begin{array}{l}\text { Share of } \\
\text { children }\end{array}$ & $\begin{array}{l}\text { Child } \\
\text { poverty } \\
\text { rate }\end{array}$ & $\begin{array}{l}\text { Poverty } \\
\text { gap }\end{array}$ \\
\hline $\begin{array}{l}\text { Main income from } \\
\text { benefit }\end{array}$ & $34.3 \%$ & $91.1 \%$ & $7.2 \%$ & $98.1 \%$ & $72.2 \%$ \\
\hline $\begin{array}{l}\text { Head or spouse main } \\
\text { income from } \\
\text { employment }\end{array}$ & $37.0 \%$ & $20.8 \%$ & $27.0 \%$ & $36.5 \%$ & $10.3 \%$ \\
\hline $\begin{array}{l}\text { Head and spouse main } \\
\text { income from } \\
\text { employment }\end{array}$ & $28.7 \%$ & $3.1 \%$ & $65.8 \%$ & $4.6 \%$ & $1.5 \%$ \\
\hline Total/average & $\mathbf{4 , 3 2 7 , 0 0 0}$ & $\mathbf{3 9 . 8 \%}$ & $\mathbf{1 , 9 5 1 , 0 0 0}$ & $\mathbf{2 0 . 0 \%}$ & $\mathbf{2 9 . 0 \%}$ \\
\hline
\end{tabular}

The data from Norway and Sweden do not have a variable for 'some' income from benefits, rather it distinguishes between the cases where the head and spouse has employment as their largest source of income, if the head or the spouse has the main income from employment, and the third group where the household's main income is from benefits.

\subsection{Spouse resemblance}

Obviously, children's income depends on parents' income, and most children still grow up in households with two adults. In many cases only one income is sufficient to keep the household out of poverty. This section will focus on the cases with two adults in the household. Previous sections have shown that this group is already less likely to be poor (not only because of increased probability of at least having one income, but also because more human capital in itself increases the 
probability of (remaining) living with a partner), but the group is still the majority, so still worth a closer look.

Differences in adults' income are driven by circumstances or co-incidents and human capital, and ultimately human capital is an important factor in explaining poverty, particularly at the individual level. If parents (or: more precisely: adults in households with children) have similar amounts of human capital that can be expected to contribute to more heterogeneous incomes for children across households, and ultimately it is possible that this accentuation of low income and/ or poverty means higher child poverty rates. This is relevant because, if the degree to which spouses share traits that predict poverty varies across countries, this may explain some of the variation in child poverty rates across countries. It is beyond the scope of this paper to measure the relationship between spouse resemblance and child poverty at macro-level, but it is possible to run some household-level analyses to establish whether the relationship is observable at all.

Tambs and Moum (1992:957-58) list three non-rival explanations of spouse resemblance: social homogamy, assortative mating and convergence during time spent together. Social homogamy is understood as spouse selection from social groups that tend to share certain characteristics, assortative mating is understood as a tendency for individuals to form partnerships with individuals with whom they share certain traits. Even though the cause of the phenomenon is not fully understood, it is beyond doubt that spouses tend to share many traits.

Obviously, when describing how spouse resemblance in human capital affects poverty rates through income, human capital cannot be operationalised as income, even though it may well be that spouses' incomes may show a homogeneous tendency. Since educational attainment is an important predictor of income and is relatively straightforward to compare across countries (as opposed to e.g. ethnicity, religious affiliation etc.), this will be used as an indicator of spouse resemblance in human capital. The argument that spouse resemblance affects child poverty among household with more than one adult rests on the assumption that homogeneous couples/parents leads to homogeneous incomes (between the spouses), which in turn leads to more heterogeneous incomes across households. This can be tested by running an OLS regression where households' 'distance' from the median income is the dependent variable, and difference in educational attainment between spouses are the main independent variable. The advantage of regression analysis is that it 
allows the inclusion of education level as control variables. Based on the theory above, the a priori expectation is a U-shaped relationship, i.e. that the divergence from the median income is largest where education is highest and lowest. In order to control for this factor, educational level and the square of the educational level of household head and spouse are included as control variables. The theory above predicts that on average there will be a positive relationship between spouse educational resemblances and the distance from the household median income. There are done several studies of the effects of the (changing) effect of education and age and other factors in the mating process.

The LIS dataset separates education level for household head and spouse into 8 tiers. In order to avoid distortion from exceptionally high incomes the natural logarithm of all income data is used. Here a square root equivalence scale is used to calculate the median income and the deviation from it. The income analysed is the market income, i.e. income before tax and transfers, because this presumably is what is most affected by human capital. An analysis of LIS-data for household with couples shows that for every standard deviation the distance in level of education between spouses increases, Norwegian households' income deviates from the median income on average by .064(2000); .116(1995); .057(1991); .055 (1986) standard deviations less. Equivalent analysis for Sweden shows somewhat weaker effects: .019(2000); .035(1995); .011(1992). 
Table 3.13 OLS Regression of household (HH) divergence from median income by education and spouse resemblance, standardized coefficients

\begin{tabular}{|c|c|c|c|c|c|c|c|}
\hline & $\begin{array}{l}\text { Norway } \\
2000\end{array}$ & $\begin{array}{l}\text { Norway } \\
1995\end{array}$ & $\begin{array}{l}\text { Norway } \\
1991\end{array}$ & $\begin{array}{l}\text { Norway } \\
1986\end{array}$ & $\begin{array}{l}\text { Sweden } \\
2000\end{array}$ & $\begin{array}{l}\text { Sweden } \\
1995\end{array}$ & $\begin{array}{l}\text { Sweden } \\
1992\end{array}$ \\
\hline $\begin{array}{l}\text { Spouse } \\
\text { difference in } \\
\text { educ. Level }\end{array}$ & $-.06 * \star$ & $-.12 \star \star$ & $-.06 \star \star$ & $-.06 * \star$ & $-.02 \star \star$ & $-.04 * \star$ & $-.01 * \star$ \\
\hline $\begin{array}{l}\mathrm{HH} \text { head } \\
\text { education level }\end{array}$ & $-.87 * \star$ & $-.32 \star \star$ & $-.15 * \star$ & $-.17 \star \star$ & $-.55 * \star$ & $-.41 * \star$ & $-.75 * \star$ \\
\hline $\begin{array}{l}\mathrm{HH} \text { head } \\
\text { education } \\
\text { level, square }\end{array}$ & $.81 * \star$ & $.26 * \star$ & $.13 * \star$ & $.15 \star \star$ & $.48 * \star$ & $.41 \star \star$ & $.64 \star \star$ \\
\hline $\begin{array}{l}\text { Spouse } \\
\text { education level }\end{array}$ & $-1.06 * \star$ & $-.49 * \star$ & $-.08 * \star$ & $-.10 * \star$ & $-.66 \star \star$ & $-.66 * \star$ & $-.79 \star \star$ \\
\hline $\begin{array}{l}\text { Spouse } \\
\text { education } \\
\text { level, square }\end{array}$ & $.89 \star \star$ & $.26 \star \star$ & $-.06 * \star$ & $-.05 * \star$ & $.57 \star \star$ & $.55 \star \star$ & $.56 \star \star$ \\
\hline R square & .11 & .10 & .03 & .03 & .06 & .05 & .22 \\
\hline N25 & 7336 & 6085 & 5576 & 3291 & 5472 & 8071 & 7995 \\
\hline
\end{tabular}

Even though the effects are not very large (as would be expected), and shows considerable variation without any clear trend over relatively short time periods, every analysis where sufficient data were available yielded results significant at a .ooo-level, and is always pointing in the expected direction. Thus the evidence provides a reasonably strong support for the theory that spouses' similarity in human capital measured as education attainment in it self contributes to child poverty.

25 The number of cases is somewhat meaningless, as the observations have been weighted to give a better picture of the total population. The number given is thus the number of observations the analysis is based on. 


\subsection{Interaction effects}

So far the various groups in which market poverty levels have been measured have been dealt with individually. While this gives a straightforward picture that is easy to read, it masks the fact that many poor households are poor not because they belong to one particularly vulnerable group, but in many cases they are poor because they belong to a certain combination of groups. Measuring poverty incidence in various groups does not capture this effect, as many of these are measured twice because they belong to two groups. This section will provide some data on the incidence and poverty rates among households and children that simultaneously belong to two groups that are likely to be poor. Unfortunately the dataset used here to analyse New Zealand does not permit this kind of analysis, so this particular analysis is limited to Norway and Sweden. As in the rest of this chapter the focus is on market poverty measured with the basis of income before taxes and transfers.

Four groups that tend to have higher poverty rates than the average are those with household head aged less than 31 years old, those with three or more children, those with immigrant background and those with only one adult in the household. The incidence and poverty among children or households that belong to some combination of these groups will be analysed in this section.

The first group to be studied here is the households with only one adult and where the adult is 30 years old or younger. For comparison incidence and poverty data on households and children in one-adult households and households where the household head is 30 years old or younger are also provided. 
Table 3.14 Market poverty in young parent and one-adult households

\begin{tabular}{|l|l|l|l|l|}
\hline Household type & $\begin{array}{l}\text { Household } \\
\text { Incidence }\end{array}$ & $\begin{array}{l}\text { Share of } \\
\text { children }\end{array}$ & $\begin{array}{l}\text { Household } \\
\text { poverty }\end{array}$ & $\begin{array}{l}\text { Child } \\
\text { poverty }\end{array}$ \\
\hline \multicolumn{5}{|c|}{ Norway } \\
\hline $\begin{array}{l}\text { All households where the head is } 30 \\
\text { or younger }\end{array}$ & $15.6 \%$ & $9.4 \%$ & $40.7 \%$ & $36.2 \%$ \\
\hline All households with only one adult & $46.6 \%$ & $15.2 \%$ & $54.7 \%$ & $58.7 \%$ \\
\hline $\begin{array}{l}\text { Households with only one adult } \\
\text { where the head is 30 or younger }\end{array}$ & $11.1 \%$ & $2.7 \%$ & $51.2 \%$ & $86.5 \%$ \\
\hline \multicolumn{5}{|c|}{ Sweden } \\
\hline $\begin{array}{l}\text { All households where the head is 30 } \\
\text { or younger }\end{array}$ & $15.2 \%$ & $7.4 \%$ & $39.8 \%$ & $40.3 \%$ \\
\hline All households with only one adult & $51.7 \%$ & $19.1 \%$ & $55.0 \%$ & $51.2 \%$ \\
\hline $\begin{array}{l}\text { Households with only one adult } \\
\text { where the head is 30 or younger }\end{array}$ & $11.3 \%$ & $2.2 \%$ & $47.8 \%$ & $81.9 \%$ \\
\hline
\end{tabular}

In the table above, the two columns to the right shows the market poverty rate in the various kinds of households. The two columns furthest to the right, column three and four, show the percentage of households and children respectively in the various categories that are poor. Column one shows the frequency of the various categories as a percentage of all households. Column two does the same for children. It shows for example that $\mathbf{1 1 . 1 \%}$ of all Norwegian households had only one adult who is also 30 years or younger. 2.7\% of all Norwegian children lived in this kind of household. These incidence figures are important in part because they show that having a young household head and being sole adult in a household is positively correlated. ${ }^{26}$ In other words are households that have young head more likely to

${ }^{26}$ To show this one can calculate what the incidence of young sole-adult households would have been if young household head and sole adult head had not been correlated. If $15.6 \%$ of the one-adult households had a head aged 30 or less (as is the case in the total population), while the frequency of one-adult households remained at $46.6 \%$, the frequency of young one-adult households would be $15.6 \%$ multiplied by $46.6 \%) 7.3 \%$. Because the order in which two numbers are multiplied does not matter, this also means that if $46.6 \%$ of all young households were oneadult households and $15.6 \%$ of all households head a young head, the frequency of young one-adult households would also be $7.3 \%$. In Sweden the equivalent figure would be $7.8 \%$. The observed frequencies are much higher. 
contain only one adult than the average household, and households that have only one adult are more likely to have a young had than the average. The row of the table also shows that of the Norwegian households that had a young and single head 51.2\% were market poor. Out of all the children living in this kind of households, 86.5\% of were market poor. Among households that have only one adult those with a young head are, in other words, less likely to be poor than the rest. As is argued previously this is probably due to low market income among the elderly. Among the households with a young head those with more than one adult are less likely to be poor than those with only one.

Also when it comes to the relative frequency of children in family types there is a correlation: Children that live with only one adult are more likely to live with a young adult, and children that live with a young adult are more likely than others to live with only one adult. While children that live with young adults and children who live with only one adult are more likely to be poor than the average child in both countries, the children that live with only one adult who also 30 years or younger has even higher risk of market poverty. These two factors combined means that it is fair to say that living with a young adult is primarily a (poverty) risk factor for children that also only live with one adult. Among these children, market poverty is the norm, not an exception. No other combination of two factors examined here gives a higher risk of market poverty.

A similar cumulative effect can be observed among children that live with two or more other children and also lives with a young household head. However, most families with a large number of children naturally have older adults, so because very few children fall into this category, no statistics will be provided here. 
Table 3.15 Market income in one-adult households with three or more children

\begin{tabular}{|l|l|l|l|l|}
\hline Household type & $\begin{array}{l}\text { Household } \\
\text { Incidence }\end{array}$ & $\begin{array}{l}\text { Share of } \\
\text { children }\end{array}$ & $\begin{array}{l}\text { Household } \\
\text { poverty }\end{array}$ & $\begin{array}{l}\text { Child } \\
\text { poverty }\end{array}$ \\
\hline \multicolumn{5}{|c|}{ Norway } \\
\hline $\begin{array}{l}\text { All households with three or more } \\
\text { children }\end{array}$ & $5.1 \%$ & $32.8 \%$ & $15.2 \%$ & $16.3 \%$ \\
\hline All households with only one adult & $46.6 \%$ & $15.2 \%$ & $54.7 \%$ & $58.7 \%$ \\
\hline $\begin{array}{l}\text { Households with only one adult and } \\
\text { three or more children }\end{array}$ & $0.2 \%$ & $2.7 \%$ & $72.2 \%$ & $72.5 \%$ \\
\hline \multicolumn{5}{|l|}{ Sweden } \\
\hline $\begin{array}{l}\text { All households with three or more } \\
\text { children }\end{array}$ & $4.3 \%$ & $31.3 \%$ & $22.3 \%$ & $24.2 \%$ \\
\hline All households with only one adult & $51.7 \%$ & $19.1 \%$ & $55.0 \%$ & $51.2 \%$ \\
\hline $\begin{array}{l}\text { Households with only one adult and } \\
\text { three or more children }\end{array}$ & $0.7 \%$ & $5.0 \%$ & $56.1 \%$ & $58.2 \%$ \\
\hline
\end{tabular}

Table 3.16 examines another combination of factors that makes households and children particularly vulnerable to poverty, namely one-adult households with three or more children. Looking first at the incidence ratios it is clear that in neither country is this group more common than would be expected based on the frequency of all households with only one-adult and the frequency of households with three or more children. This observation also holds true when looking at the data for children. So, even though those living both with a single adult (or alone) and three or more children are substantially more likely to be market poor, this combination of factors are not more common than the two factors seen in isolation.

Table 3.16 Market income in one-adult, immigrant households

\begin{tabular}{|l|l|l|l|l|}
\hline Household type & $\begin{array}{l}\text { Household } \\
\text { Incidence }\end{array}$ & $\begin{array}{l}\text { Share of } \\
\text { children }\end{array}$ & $\begin{array}{l}\text { Household } \\
\text { poverty }\end{array}$ & $\begin{array}{l}\text { Child } \\
\text { poverty }\end{array}$ \\
\hline \multicolumn{5}{|c|}{ Norway } \\
\hline $\begin{array}{l}\text { All households with only one } \\
\text { adult }\end{array}$ & $46.6 \%$ & $15.2 \%$ & $54.7 \%$ & $58.7 \%$ \\
\hline All immigrant households & $7.9 \%$ & $11.8 \%$ & $36.0 \%$ & $28.9 \%$ \\
\hline $\begin{array}{l}\text { Immigrant households with } \\
\text { only one adult }\end{array}$ & $3.0 \%$ & $1.5 \%$ & $57.7 \%$ & $68.9 \%$ \\
\hline \multicolumn{7}{|c|}{ Sweden } & $19.1 \%$ & $55.0 \%$ & $51.2 \%$ \\
\hline $\begin{array}{l}\text { All households with only one } \\
\text { adult }\end{array}$ & $51.7 \%$ & $20.7 \%$ & $43.6 \%$ & $35.6 \%$ \\
\hline All immigrant households & $14.1 \%$ & $3.4 \%$ & $60.5 \%$ & $61.1 \%$ \\
\hline $\begin{array}{l}\text { Immigrant households with } \\
\text { only one adult }\end{array}$ & $6.2 \%$ &
\end{tabular}

The table above shows the same statistics as the previous one, but with focus on households that are both immigrant and have only one adult. In both countries this particular group is smaller than expected: i.e. households with only one adult are 
slightly less likely to be immigrant than the average of all households and conversely: immigrants are slightly less likely to live in households with only one adult than the rest of the population. The data is mainly shaped by findings established in previous sections: immigrants are more likely to be poor than the average, especially in Sweden and among children. The impact of having only one adult in the household is substantially larger in all cases. In the households that are both immigrant and oneadult the probability of being poor is slightly higher than the average of all one-adult households. The same observation is true, in fact even more so, when the unit of analysis is children.

\section{Table 3.17 Market income in immigrant households with 3 or more children}

\begin{tabular}{|l|l|l|l|l|}
\hline Household type & $\begin{array}{l}\text { Household } \\
\text { Incidence }\end{array}$ & $\begin{array}{l}\text { Share of } \\
\text { children }\end{array}$ & $\begin{array}{l}\text { Household } \\
\text { poverty }\end{array}$ & $\begin{array}{l}\text { Child } \\
\text { poverty }\end{array}$ \\
\hline \multicolumn{5}{|c|}{ Norway } \\
\hline $\begin{array}{l}\text { All households with three or more } \\
\text { children }\end{array}$ & $5.1 \%$ & $32.8 \%$ & $15.2 \%$ & $16.3 \%$ \\
\hline All immigrant households & $7.9 \%$ & $11.8 \%$ & $36.0 \%$ & $28.9 \%$ \\
\hline $\begin{array}{l}\text { Immigrant households with three } \\
\text { or more children }\end{array}$ & $0.6 \%$ & $4.2 \%$ & $30.3 \%$ & $33.4 \%$ \\
\hline \multicolumn{2}{|l|}{ Sweden } & & & \\
\hline $\begin{array}{l}\text { All households with three or more } \\
\text { children }\end{array}$ & $4.3 \%$ & $20.7 \%$ & $43.6 \%$ & $24.2 \%$ \\
\hline All immigrant households & $14.1 \%$ & $7.7 \%$ & $46.7 \%$ & $35.6 \%$ \\
\hline $\begin{array}{l}\text { Immigrant households with three } \\
\text { or more children }\end{array}$ & $1.0 \%$ & $22.3 \%$ & $49.7 \%$ \\
\hline
\end{tabular}

The final table in this section analyses the situation for those living in immigrant households with three or more children. Being immigrant increases the probability of having many more than two children living in the household, but not dramatically so, especially when looking at children. Nonetheless, this is a group that contains a substantial number of children, despite the relatively narrow definition. It is also a group that experiences higher risk of poverty than the two groups it is constructed of and is compared with here. Some simple fractions from the table provide an illustration of why it is fruitful to look at how effects can be "compounded": one fifths of all Swedish children were (market) poor according to the methodology applied in this study. Out of those living with three or more children in the household this increases to nearly one quarter, and among children living in households with some form of immigrant background, over one third are 
poor. However; children in immigrant households with more than two children has a nearly $50 \%$ probability of being poor.

Further to these combinations of two factors it is also possible to study combinations of three factors. For example one could study poverty levels of immigrants with only one adult and more than two children. Obviously this would mean an even smaller group with even higher risk of poverty (child poverty rates of 89.2\% and $85.7 \%$ in Norway and Sweden, respectively).

A more general finding that can be confirmed on the basis of this section is that, in categories of households that are more likely to be poor than the average household, this effect is usually even stronger for children living in this type of household.

This section has not attempted to explain why these particular combinations of factors "compounds" the risk of market poverty to varying degree, the point here is to demonstrate that it is possible and meaningful to study the effect of several variables simultaneously. It also shows how increased detail can predict or explain poverty levels more accurately. This is important both for policymaking and normative debates about poverty. For example, it is worth noting that many of the categories used here do not change often (if at all, the case in point being the immigrant status). That those variables can explain much of the variation in poverty is reason for concern because it means that individuals that are in major risk of poverty today are likely to be at risk tomorrow as well. That this effect is stronger among children has profound implications for the risk of poverty being passed on across generations, and this should be kept in mind by policy-makers who regards equal opportunities as an important goal. The next chapter will deal with how the outcomes of policy affect this picture. 


\section{Policy}

This chapter will focus on poverty using households' disposable income. This is important because it gives an impression of actual poverty levels, but also because when it is contrasted with market income poverty described in the previous chapter that describes the impact that governments make on poverty through taxes and transfers. The first section of the chapter will look closer at the conceptual difference between market and disposable income, and how these are affected by taxes and transfers. It is followed by a section on policy differences in the three countries. The third section explores methodology and findings in a cross-national study looking at factors that determine how effective governments are at reducing poverty. The next sections will look at the effects of government intervention on poverty from a micro-perspective in the same way as was done in chapter 3.2-3.8. 


\subsection{Market and disposable income, taxes and transfers}

Taxes are deducted from households' market income ${ }^{27}$ and can thus bring households with a market income, which would otherwise be above the poverty line, below the poverty line. Furthermore, taxation can deepen the poverty for households with a market income that is below the poverty line. Government social spending on transfers has the opposite effect: boosting households' income can bring them out of poverty or relieve it. Obviously the design and type of taxes and transfers affect the rate at which this happens.

Two factors that make it reasonable to assume that the net effect of government interventions is to reduce poverty (in other words that transfers bring more people out of poverty than taxes bring households into poverty). Although some benefits are taxed (notably in New Zealand, although only the net amount is paid out) taxes affect mainly people with access to a market income, and affect those with large market incomes the most. The degree to which taxes affect rich households more than poor households depend on how progressive the taxation is, as well as the tax base definition i.e. what economic activity is eligible for taxation. Norway, for instance, has a wealth tax which is more limited in the two other countries. Clearly, the larger share of the economy that the government raises in (income) taxes, the larger the gross effect on households' income will be.

The other factor that makes the net effect of government interventions lower poverty is that transfers for the most part benefit poorer household more than rich households. Here, the degree to which a given amount of money spent on transfers reduces poverty depends on the degree of universalism of transfers or benefits. Transfers that are income tested, or targeted, benefit mostly households that are in (or have a high risk of) poverty, while universal benefits are spread out relatively evenly on the population. Similarly as with taxes, the larger share of the economy that is used on transfers, the bigger the effect on households' income and poverty will be.

The conclusion is that high taxes increases poverty, but the effect decreases if they are progressive. Transfers reduce poverty, especially if they are

\footnotetext{
${ }^{27}$ While there are many ways that governments can raise money, in this case it is not unreasonable to assume that income taxes are a dominant source of income for governments.
} 
income tested. Two factors make this picture more complicated. First, while transfers affect all eligible households, income taxes and their progressiveness affect mainly households with a taxable market income (i.e. households with employed individuals, and in the cases where pensions or benefits are taxed).

Second, so far the argument has assumed that households' disposable income does not affect their market income, which clearly is not the case. Increases in the marginal tax rates means that increases in market income has less effect on the disposable income. Market income is in part a result of the employment decisions of the adults in households, and these are to some extent affected by incentives to increase the disposable income. Employment decisions also affect economic activity levels, but in terms of relative poverty it is not clear what the effect would $\mathrm{be}^{28}$, since economic activity may raise the median income and thus also the poverty line.

However, the effect of increased levels of employment is first and foremost higher market income for the individual household who move into employment at an adequate income. How much higher depends on the labour market and its institutions, some of which can be influenced by the government, such as a legal minimum wage. When individuals make employment decisions they are concerned with the effect on their disposable income, of which the market income is only one (albeit large) fraction. Obviously, taxes will affect how much of an increase in market income is retained in the disposable income. When looking at poverty specifically, this marginal tax rate is frequently low, since low income households should benefit from many of the available deductions. A highly progressive tax system could thus give poor households a low marginal tax rate, even if the overall tax rate is relatively high.

The relation between market and disposable income (and thus the incentives in employment decisions) is also affected by government transfers. This could be expressed in the effective marginal tax rate (Stephens, 1999:97) which takes into account that income tested transfers can reduce the incentives to increase the market income through the labour market. Since low income households often face a relatively low income tax rate, the reduction in income tested transfers that could follow from an increased market income could in some cases be a more important factor than taxes for employment decisions in low income households. The effective marginal tax rate (as opposed to the marginal tax rate) is the sum of the marginal

${ }^{28}$ While the question is an interesting one, it is beyond the scope of this thesis to delve deeper into it. 
income tax rate and the rate at which transfers are reduced when market income is marginally increased.

This means that a government wishing to reduce poverty by redistributing income faces a choice beyond how much income it wishes to redistribute. It also has to decide how progressive the tax rate should be, and whether transfers should be universal or targeted. A targeted benefit system could increase the disposable income of poor households for a relatively small expenditure, or conversely, could increase the disposable income of poor households more for the same expenditure. The downside of this solution is that it would run the risk of reducing the incentive of the poor to increase their market income through increased levels of employment, through what is also known as the negative income tax. The alternative way to ensure adequate level of disposable incomes for everyone is through universal transfers, e.g. child benefits. These do not raise the effective marginal tax rate, but does of course require far larger expenditures, and will thus, ceteris paribus, require a higher tax level to be funded if poverty is to be relieved. As has already been established, increased income taxes can reduce labour supply incentives through tax avoidance. This affects primarily households with middle or higher incomes. The choice between universal and targeted benefits is of course not a choice between two absolutes, taxing the benefit and making the cut-off points for targeted benefits gradual and generous ${ }^{29}$ can offer some compromises. A highly progressive tax system can also go some way in offering a solution, but since it only affects households with a market income the dilemma remains: which group should 'pay' for poverty reduction in the form of higher effective marginal tax rates, the low income groups (targeted benefits) or middle to high income groups (universal benefits, with higher overall tax level)? Atkinson (1996) introduces the perennial issue of economic growth into this discussion, and argues that contrary to the orthodoxy of economic theory at the time, there are also reasons to believe that offering more or less extensive safety nets can have some positive effects as well, pointing towards some of the strengths of what would later be known as the flexicurity model (Madsen, 2005).

Facing this dilemma it is clearly important to know who the market income poor are, and whether they face a real choice in the labour market. If the

\footnotetext{
${ }^{29}$ Generous should here be interpreted as offering some benefits to households that are slightly above the poverty line.
} 
market income poor are mostly households that for some reason have no way of increasing their market income, it does not matter if they face a high effective marginal tax rate. Thus, if the goal is to reduce poverty while minimising the effective tax rate for those that can affect their market income, the optimal solution is targeted benefits to people already working long hours (who still don't earn enough to avoid poverty), caregivers, disabled or sick people and others that cannot be expected increase their level of employment. Establishing rules for determining who are in a position where it is possible to increase levels of employment does, however, present vast normative, conceptual, legal and practical difficulties. Despite looking at many different variables, chapter 3 in this thesis does not provide more than a few clues to how many of the market income poor that could escape poverty through increased employment levels. This suggests that it is hard for governments to know how much poverty would be relieved by higher wage and employment levels, and it is limited how much governments can affect these in a sustainable manner.

There are also a wide range of other considerations that have made some policymakers introduce benefits without income testing. The political support for benefits is presumably higher when they benefit the entire population. Some benefits incorporate an element of compulsory insurance on areas where information asymmetry makes voluntary and sometimes also commercial insurance impossible (Esping-Andersen, 1999). Other benefits redistribute income between age groups, or encourage certain type behaviour that the government considers have positive externalities. There may also be less social stigma connected to receiving benefits based on universal rights.

Child poverty poses a particular challenge for governments, because while children are affected by poverty in their household, they are not making the employment decisions for the adults in the household ${ }^{30}$. The literature surveyed in section 2.2 suggests that exposure to poverty as a child has lasting negative consequences for individuals affected and the wider society. Even though households with adults in child-rearing age (see figure 3.2) are not as likely to have a market income below the poverty line as those in retirement age, their income peaks on average almost 20 years later (see tables 3.10), suggesting that there is scope for redistributing from the age-group that are at their market income peak to those in

\footnotetext{
${ }^{30}$ Children can of course make employment decision for themselves, but it seems unlikely that the income of underage children is a sufficient solution to poverty that does not harm education attainment and thus lifetime income opportunities.
} 
child-rearing age. The aging population (driven by fertility below the replacement rate and increases in life expectancy), means that the dependency ratio is dropping. This suggests that there are long term positive externalities associated with making child-rearing more attractive. These factors are all reasons why governments to varying degrees use universal tools such as child benefits to redistribute to households with children. 


\subsection{Tax and transfer policies in New Zealand and Scandinavia}

OECD provides extensive data on tax and spending data in the three countries. Since the focus in this thesis is on relative poverty, it is natural to focus on the spending and taxes as a share of the countries' total GDP, rather than absolute figures per capita. As is shown in figure 4.1, in year 2000 New Zealand had the lowest tax revenue at 33.6 per cent of GDP, Norway was in the middle at 43.0 per cent, well below Sweden which had the highest largest tax revenue in OECD at 53.4 per cent of GDP. Year 2000 was also the year when Sweden's tax revenue as a share of the GDP peaked.

Figure 4.1 Total tax revenue, $1955-2005$

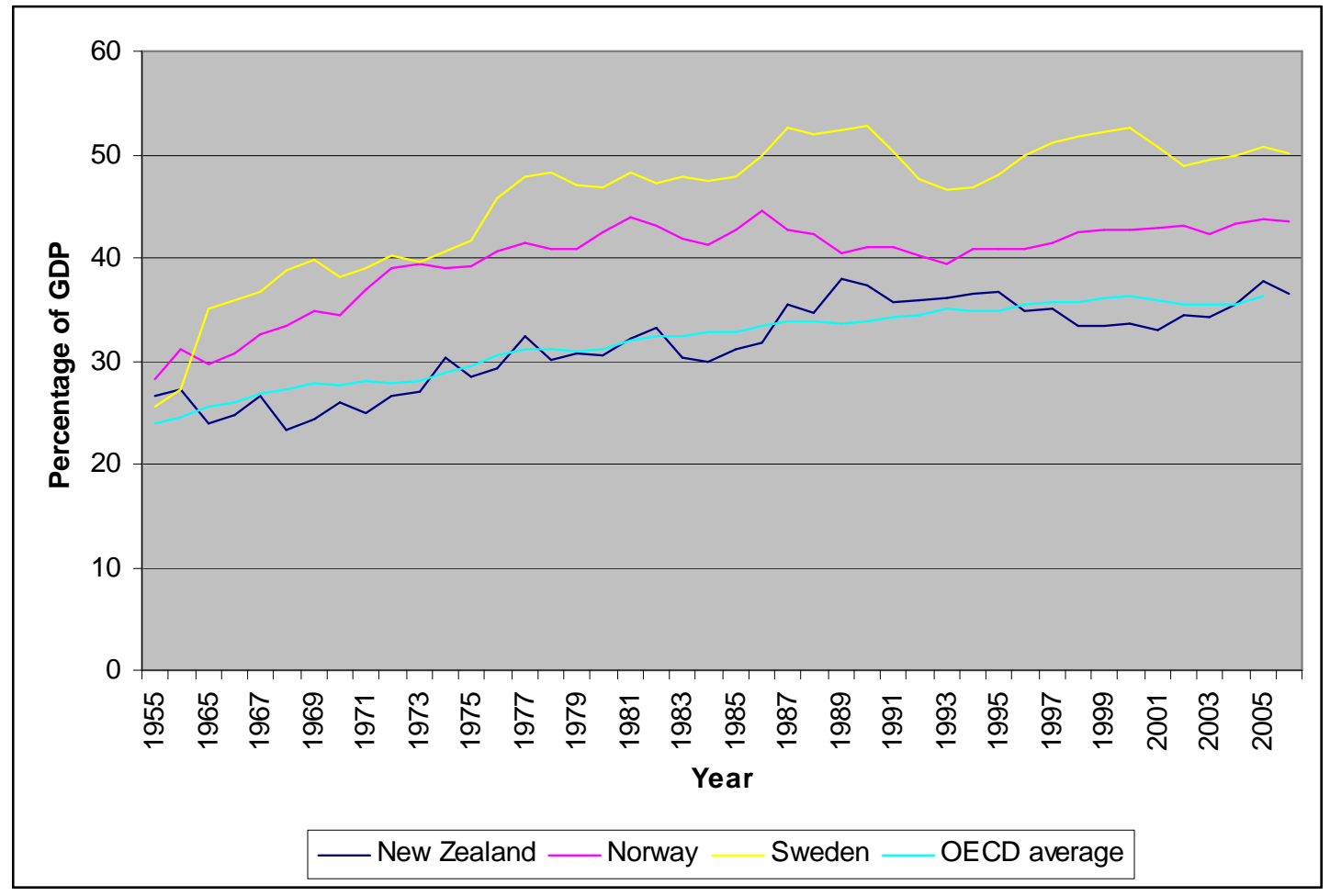

Source: OECD Stats: Total tax revenue, Country comparison from http://stats.oecd.org/wbos/(2008, 30/4) 
Figure 4.2Public sector social expenditure as a percentage of GDP

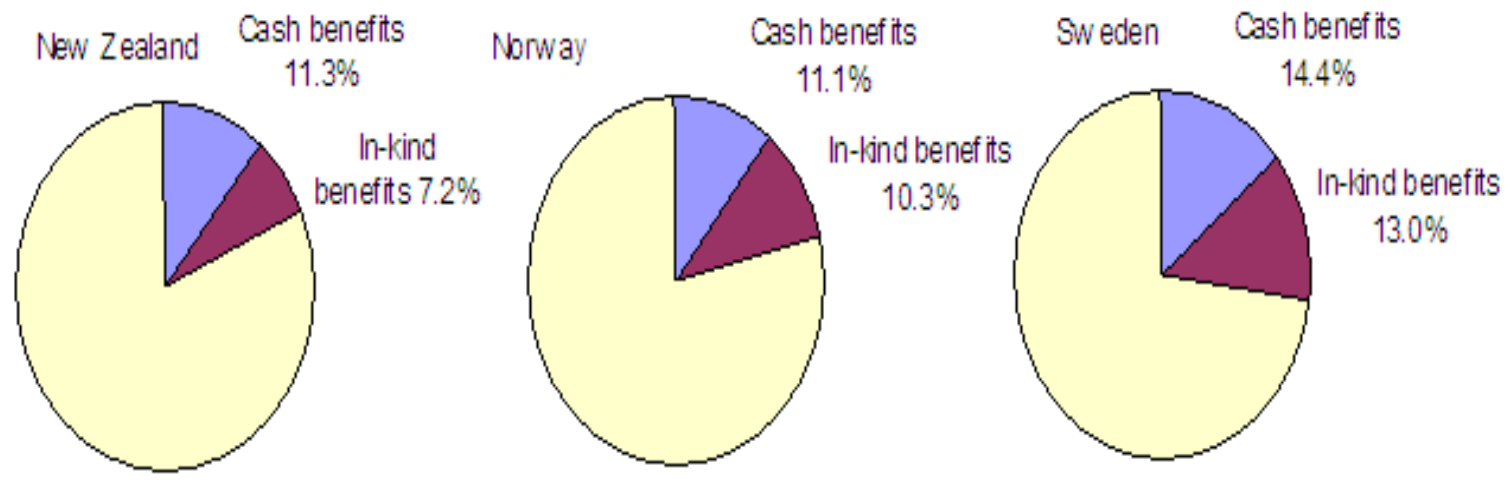

Source: OECD Stats: Social Expenditure - Aggregated data fromhttp://stats.oecd.org/wbos/(2008, 30/4)

Figure 4.2 shows that the government expenditure on the social sector as a share of GDP was relatively similar across the three countries. The differences between New Zealand and Norway are relatively small, but the relative proportion of the spending is in the order that e.g. Esping-Andersen (1999, 1990) would presumably predict based on perceptions of welfare regime (New Zealand as "liberal" with smaller spending proportion than the "socialdemocratic" Scandinavian countries), with the exception that Norway spent less than New Zealand on cash benefits. Two possible explanations of the difference between Norway and Sweden could be role of the high-productivity petroleum industry in the Norwegian private sector and the age composition where Norway has a slightly larger share of the population in working age. 


\subsection{Cross-national explanations of poverty reduction}

Moller et al. (2003) find that, out of the variables listed in section 3.1, unemployment rates, politically left cabinet, lack of constitutional veto points and welfare generosity, were the predictors of high reduction of whole-population poverty rates from taxes and transfers. In their model they achieved a $\mathrm{R}^{2}$ of $.91 .3^{31}$ Garfinkel, Rainwater, \& Smeeding (2006:898) argue that a limitation of this and other research that attributes differences in inequality between countries to "history, culture and political choices rather than to income and demography [... and] contrast the strength of the Scandinavian labo[u]r movements and their social democratic parties that are committed to reducing class and gender inequalities to the strength of the $19^{\text {th }}$-century liberal belief in limited government in the English speaking countries" is that it does not take into account in-kind transfers and indirect taxes.

This criticism merits some further comments. It is obvious that comparative studies of government welfare policy and inequality should take into account welfare spending beyond transfers. However, it is not entirely accurate that the literature Garfinkel et al (2006) criticise does not take public spending on in-kind benefits into account. The most obvious counterexample is the work of EspingAndersen (1999, 1990) who extensively studies public spending on government production of goods and services as well as income redistribution, although he focuses mostly on the impact on the labour market, rather than as a measure of inequality. Secondly, while it is obvious that in-kind benefits should not be overlooked when considering governments' redistributive efforts, there are many problems associated with including this spending in income statistics for individuals, which the authors acknowledge. Their model builds on the assumption that government expenditure on in kind provision of goods and/or services reflect their value to the recipients. There are obvious problems with comparing the efficiency of the process where expenditure is transformed into services across countries. In some cases the model also assumes that the public goods are distributed equally. Another potential problem is that using the same equivalence scale for in-kind provisions of goods and services and cash benefits assumes that there are economies of scale in in-

${ }^{31}$ This means, somewhat simplistically put, that the model could account for $91 \%$ of the variation in the dataset. 
kind benefits, which may not be an accurate representation of reality, and is potentially problematic because goods and services may not be redistributed within the household as readily as cash.

That counting in-kind benefits' cash value and including these in income statistics lowers inequality between households in any given country is not surprising. This is because by assuming that in-kind benefits are distributed equally (i.e. the same amount to every individual, without regard for contributions paid in tax), while taxes are usually related to income, it follows logically that this will have a progressive effect. What makes Garfinkel et al's (2006) findings interesting, though, is that it changes the ranking between countries. Using their measure of inequality the 'three worlds of welfare' (inter alia Esping-Andersen, 1990) evaporates. This is partly because some of the countries whose welfare regime conventionally is counted as 'liberal', (notably the US) use food stamps and other similar voucher systems.

Ultimately, this question boils down to what form of inequality one wishes to measure. Partly because of the conceptual and methodological challenges outlined above, most research that attempts to measure post-transfer inequality/poverty measures cash and near-cash income, ignoring spending on items such as health and education. The degree to which it is useful to include in-kind benefits in comparative studies depends, among other factors, on the variation in private funding of these products across the countries, because this reflects the (potentially unequal) level of expenditure on these items. Including in-kind benefits has the potential of opening the proverbial can of worms, in the sense that when inkind benefits provided by the state one needs to justify why one does not include other non-cash factors such as employer provided "perks", infrastructure, environment, security, etc. in the measure of equality. This conceptual quagmire is avoided when measuring cash income exclusively. Cash differs from other goods in that it can be used to acquire many goods, rather than being an inherent good itself.

It is not clear why indirect taxes (typically Value Added Tax, (VAT) or Goods and Services Tax, GST) should affect poverty rates if poverty is defined in relative terms and the taxes are charged at a fixed rate, and savings are unaccounted for. Incorporating the savings rate is not particularly meaningful if wealth and longitudinal effects are unaccounted for ${ }^{32}$, which means that expenditure are this obviously cannot be sustained over very long time, and the individuals that are exposed to poverty 
assumed to be equal to income, and the tax thus affect all income at the same proportion. Thus, while it is true that indirect taxes are regressive (Garfinkel, et al., 2006:902), they should lower the income and the poverty threshold by an equal proportion, and the poverty rate should be unchanged. While GST lowers disposable income, revenue neutral tax reforms would need to replace GST with personal income taxes, and the net incidence change for the poor would be small. In this author's view, correcting for VAT or GST when measuring how much a given income can buy is not necessary when using a relative definition of poverty in Scandinavia and New Zealand. contain a bias from self-employed who understate their income, without having the traditional challenges of other income poor. 


\subsection{The effect of government intervention on poverty in New Zealand and Scandinavia}

Table 4.1 below shows the proportion of children and households that falls below the 60 per cent of median income poverty line. The first two columns show the poverty rate by market income (as described in chapter three) and disposable income. Disposable income is the income that households have available to spend, and is thus the real observed poverty. In the household rows the number of poor and non-poor households is counted to calculate the household poverty rate (which in other words does not describe the proportion of poor people, but the proportion of poor households), while in the child rows the poor and non-poor children are counted to calculate the child poverty rate. The same measure of poverty and thus the same poverty line is used for market and disposable income, as well as for calculating the poverty gap. 
Table 4.1 Child and household poverty rates by market and disposable income in New Zealand and Scandinavia

\begin{tabular}{|c|c|c|c|c|c|c|c|}
\hline & 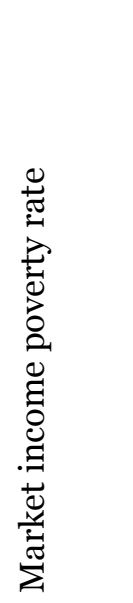 & 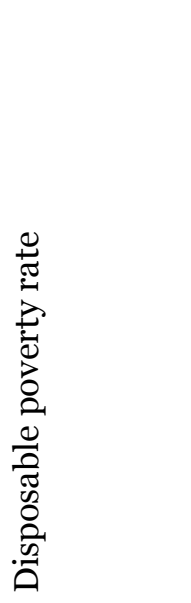 & 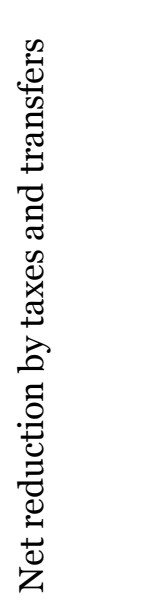 & 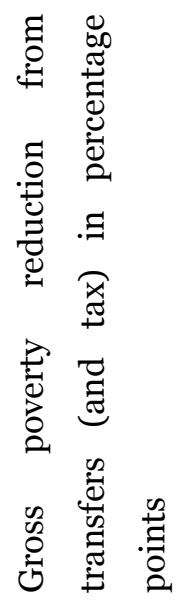 & 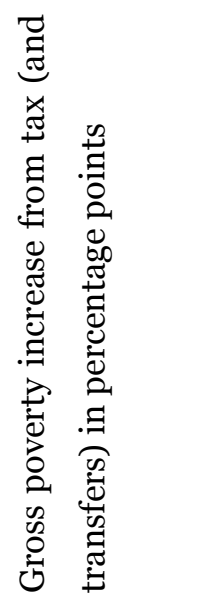 & 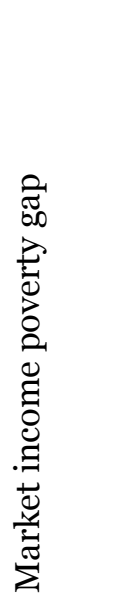 & 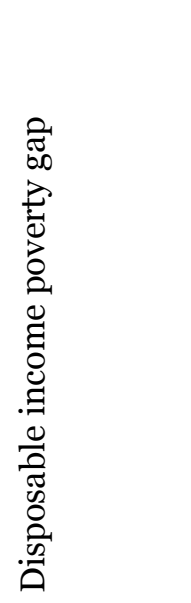 \\
\hline $\begin{array}{l}\text { New } \\
\text { Zealand } \\
\text { households }\end{array}$ & $32.7 \%$ & $18.0 \%$ & $45.0 \%$ & * & * & $74.0 \%$ & $15.6 \%$ \\
\hline $\begin{array}{l}\text { New } \\
\text { Zealand } \\
\text { children }\end{array}$ & $29.9 \%$ & $24.3 \%$ & $18.7 \%$ & * & * & $63.0 \%$ & $18.6 \%$ \\
\hline $\begin{array}{l}\text { Norwegian } \\
\text { households }\end{array}$ & $36.1 \%$ & $18.6 \%$ & $48.5 \%$ & $18.5 \%$ & $1.0 \%$ & $24.8 \%$ & $5.0 \%$ \\
\hline $\begin{array}{l}\text { Norwegian } \\
\text { children }\end{array}$ & $16.4 \%$ & $6.6 \%$ & $59.8 \%$ & $10.5 \%$ & $0.6 \%$ & $9.0 \%$ & $1.7 \%$ \\
\hline $\begin{array}{l}\text { Swedish } \\
\text { households }\end{array}$ & $39.8 \%$ & $13.0 \%$ & $67.3 \%$ & $27.5 \%$ & $0.6 \%$ & $29.0 \%$ & $4.2 \%$ \\
\hline $\begin{array}{l}\text { Swedish } \\
\text { children }\end{array}$ & $20.0 \%$ & $5.6 \%$ & $72.0 \%$ & $14.6 \%$ & $0.2 \%$ & $13.0 \%$ & $1.5 \%$ \\
\hline
\end{tabular}

(Sources: LIS 2000, New Zealand HES 2000/2001; * No data)

The difference between market income poverty and disposable income poverty is described in the third column; it describes the proportion of the households or children with a market income below the poverty line that the net effect of taxes and transfers brings above the poverty line. This means that 45 per cent of the New Zealand households that have a market income below the poverty line are brought above it by transfers, but only $18.7 \%$ of children.

The fifth column shows the proportion of the total (number of households or children) that has a market income above the poverty line but a disposable income below this line. In other words the households that pays more in tax than they receive in benefits, and where this gap is large enough to bring them below the 
poverty line. Clearly, this effect hits a very small part of the population where data are available. Data are not available for New Zealand, which is particularly unfortunate since New Zealand also eradicates a very small proportion of the total child poverty compared to the two other countries, and this may or may not be a result of the tax effect. The fourth column shows the gross effect of government interventions, in other words the proportion of households or children that transfers bring out of poverty, not subtracting those that taxes bring into poverty (column five, which is the difference between this column and column three).

Columns six and seven give the data on poverty depth in the measure as used in chapter 3, namely the average gap between observed income and the poverty line in the households that fall below it. Column six uses the market income data as described in chapter three, while column seven describes the actual poverty depth in disposable income.

It was only in New Zealand that child poverty rates were higher than poverty rates weighted by households. The findings in the column showing disposable income poverty gap mirrors the findings for the poverty rate: in New Zealand children were worse off than households without children, and the reverse was the case in Scandinavia. This shows that not only were children in New Zealand more likely to be poor, those that were poor were also poorer, relative to households without children. When discussing the poverty depth it is also worth noting that the market income gap was larger among households with children than those without. As noted this is reversed by the effect of taxes and transfers.

The data on poverty reduction confirm a trend clearly shown in a crosscountry analysis done by Whiteford and Adema (2007), namely that in countries with high levels of poverty reduction through redistribution, more of the reduction will benefit children. This fits for Norway (at least when looking at poverty depth) and Sweden, in that they remove much of the overall (i.e. household) market income poverty through government intervention, and that this effort benefits children even more than adults. New Zealand is a case of the opposite; less than half of the households in market income poverty are brought above the poverty line by redistribution, and government intervention appears to make only a limited impact on child poverty. That said, this only holds for poverty rates or the frequency of poverty, less so for poverty depth; income redistribution in New Zealand reduces the poverty gap substantially, whereas in Norway and Sweden the impact is more 
modest, primarily because the market income gap was many times larger in New Zealand than in Scandinavia. As pointed out in section 3.3 this is partially because of different definitions of old age pensions. 


\subsection{Income redistribution and ethnicity}

As discussed in section 3.2, ethnicity's (and to some extent, immigration) effect on poverty is particularly interesting because usually it is not the result of conscious decisions and usually does not change. Regression analysis of Norwegian data showed that immigrant households per se were no worse off than the total population, but when considering the demographic composition of the immigrant population, immigrant households, and immigrant children in particular, were more likely to be poor and poorer than comparable groups without immigrant background. This result means that since the New Zealand data did not allow multivariate analysis, the New Zealand findings are not conclusive. The discrepancy between the ethnic groups were so large (again, especially for child poverty) that it still provided strong evidence suggesting that ethnicity is an important factor in predicting market income poverty.

That chapter 3 found that ethnicity and immigrant background is a factor that is correlated with market income poverty, presents arguments in favour of considering ethnicity as a factor when designing policies aimed at reducing poverty. This could be done (and is done) both through policies aimed at ethnic groups directly, and through policies directed at households at risk at poverty regardless of ethnicity, but that will benefit certain ethnic groups more than others because of their composition.

This section will look at data on the effect of government intervention on poverty in various ethnic groups in the three countries. This will show to what extent income redistribution reduces poverty differences between ethnic groups, and as far as data allow, it will show to what extent certain ethnic groups benefits more from government intervention than others. As shown in chapter 3, this must in part be seen in the context of demographic composition, and part of the analysis will therefore be in later sections. 
Table 4.2 A New Zealand child and household poverty by ethnicity

\begin{tabular}{|c|c|c|c|c|c|c|}
\hline $\begin{array}{l}\text { Ethnicity by } \\
\text { household } \\
\text { head }\end{array}$ & $\begin{array}{l}\text { Proportion } \\
\text { of total }\end{array}$ & $\begin{array}{l}\text { Market } \\
\text { income } \\
\text { poverty } \\
\text { rate }\end{array}$ & $\begin{array}{l}\text { Disposable } \\
\text { income } \\
\text { poverty rate }\end{array}$ & $\begin{array}{l}\text { Net } \\
\text { poverty } \\
\text { reduction }\end{array}$ & $\begin{array}{l}\text { Market } \\
\text { income } \\
\text { poverty } \\
\text { gap }\end{array}$ & $\begin{array}{l}\text { Disposable } \\
\text { income, } \\
\text { poverty gap }\end{array}$ \\
\hline $\begin{array}{l}\text { European } \\
\text { household }\end{array}$ & $80.1 \%$ & $31.0 \%$ & $16.0 \%$ & $48.4 \%$ & $74.6 \%$ & $14 \%$ \\
\hline $\begin{array}{l}\text { Māori } \\
\text { Household }\end{array}$ & $11.2 \%$ & $44.1 \%$ & $27.4 \%$ & $37.9 \%$ & $70.9 \%$ & $18 \%$ \\
\hline $\begin{array}{l}\text { Pacific } \\
\text { households }\end{array}$ & $3.5 \%$ & $45.4 \%$ & $31.3 \%$ & $31.1 \%$ & $76.3 \%$ & $20 \%$ \\
\hline Other, $\mathrm{HH}$ & $5.2 \%$ & $27.1 \%$ & $20.05 \%$ & $26.0 \%$ & $73.6 \%$ & $28 \%$ \\
\hline Total, HH & $1,374,000$ & $32.7 \%$ & $18.0 \%$ & $45.0 \%$ & $74.0 \%$ & $15.6 \%$ \\
\hline $\begin{array}{l}\text { European } \\
\text { children }\end{array}$ & $68.3 \%$ & $22.8 \%$ & $20.9 \%$ & $8.3 \%$ & * & * \\
\hline $\begin{array}{l}\text { Māori } \\
\text { Children }\end{array}$ & $16.6 \%$ & $47.2 \%$ & $33.2 \%$ & $29.7 \%$ & * & * \\
\hline $\begin{array}{l}\text { Pacific } \\
\text { children }\end{array}$ & $7.6 \%$ & $51.7 \%$ & $34.2 \%$ & $33.8 \%$ & * & * \\
\hline $\begin{array}{l}\text { Other, } \\
\text { children }\end{array}$ & $7.4 \%$ & $34.4 \%$ & $25.3 \%$ & $26.5 \%$ & * & * \\
\hline $\begin{array}{l}\text { Total, } \\
\text { children }\end{array}$ & 886,000 & $29.9 \%$ & $24.3 \%$ & $18.7 \%$ & $63.0 \%$ & $18.6 \%$ \\
\hline
\end{tabular}

(Source: New Zealand HES 2000/2001; * No data)

The New Zealand data use, as in chapter 3, household head's ethnic affiliation. Table 4.2A has two rows for every group of ethnicities recognised in the HES dataset, one weighted by households and one by children, as well as two total rows, with data equal to table 4.1. The first column shows the relative frequency of households and children (in households) of household head's ethnic affiliation, while the other columns have the same content as their equivalents in table 4.1. Also see table $3.13 \mathrm{~A}$ for information on household size and number of children and adults per households in various ethnicities.

The data on households show that income redistribution in the ethnic groups with the highest market poverty rates, Māori and Pacific Islanders, brings a smaller proportion out of poverty than the average, even though the higher poverty rate means that a larger proportion of households are brought out of poverty. The 
income redistribution effect on the two groups with lower market poverty rates than average; 'European' and 'others' is in stark contrast, showing completely opposite outcomes. While the poverty reduction in European households is higher than the average on all accounts, the effectiveness of government poverty reduction through tax and transfers is only about half of the average in the 'other' group. This is presumably partly a function of pensions: more Europeans are elderly and thus receives superannuation. The data on child poverty show a more consistent pattern; that the higher the poverty rate, the larger the reduction through government intervention. In sum this means that European households with children tend to be in work.

However, the interpretation of these findings, especially the data on households, requires caution because, as the Norwegian data in chapter 3 demonstrated, the population in different ethnic groups may not be comparable. A possible explanation for the low rate of poverty reduction in 'other' households could be that these tend to be younger households that are still within working age, whereas the market poor in the other ethnic categories to a larger extent are retired old-age pensioners without market income, who therefore benefit from the age pension. The different picture of child poverty would be consistent with this hypothesis.

Table 4.2 B Norwegian child and household poverty by ethnicity

\begin{tabular}{|l|r|r|r|r|r|r|}
\hline & $\begin{array}{l}\text { Proportion } \\
\text { of total }\end{array}$ & $\begin{array}{l}\text { Market } \\
\text { income } \\
\text { poverty } \\
\text { rate }\end{array}$ & $\begin{array}{l}\text { Disposable } \\
\text { income } \\
\text { poverty rate }\end{array}$ & $\begin{array}{l}\text { Net } \\
\text { poverty } \\
\text { reduction }\end{array}$ & $\begin{array}{l}\text { Market } \\
\text { income } \\
\text { poverty } \\
\text { gap }\end{array}$ & $\begin{array}{l}\text { Disposable } \\
\text { income, } \\
\text { poverty gap }\end{array}$ \\
\hline $\begin{array}{l}\text { Immigrant } \\
\text { households }\end{array}$ & $9.6 \%$ & $36.0 \%$ & $25.6 \%$ & $28.9 \%$ & $25.8 \%$ & $9.8 \%$ \\
\hline $\begin{array}{l}\text { Total } \\
\text { households }\end{array}$ & $\mathbf{2 , 0 9 3 , 5 1 5}$ & $36.1 \%$ & $18.6 \%$ & $48.5 \%$ & $24.8 \%$ & $5.0 \%$ \\
\hline $\begin{array}{l}\text { Immigrant } \\
\text { children }\end{array}$ & $\mathbf{1 1 . 8 \%}$ & $28.9 \%$ & $15.5 \%$ & $46.4 \%$ & $18.3 \%$ & \\
\hline $\begin{array}{l}\text { Total } \\
\text { children }\end{array}$ & $\mathbf{1 , 0 5 1 , 7 1 5}$ & $16.4 \%$ & $6.6 \%$ & $59.8 \%$ & $9.0 \%$ & \\
\hline
\end{tabular}

(Source: LIS 200O) 
Table 4.2 C Swedish child and household poverty by ethnicity

\begin{tabular}{|l|r|r|r|r|r|r|}
\hline & $\begin{array}{l}\text { Proportion } \\
\text { of total }\end{array}$ & $\begin{array}{l}\text { Market } \\
\text { income } \\
\text { poverty } \\
\text { rate }\end{array}$ & $\begin{array}{l}\text { Disposable } \\
\text { income } \\
\text { poverty rate }\end{array}$ & $\begin{array}{l}\text { Net } \\
\text { poverty } \\
\text { reduction }\end{array}$ & $\begin{array}{l}\text { Market } \\
\text { income } \\
\text { poverty } \\
\text { gap }\end{array}$ & $\begin{array}{l}\text { Disposable } \\
\text { income, } \\
\text { poverty gap }\end{array}$ \\
\hline $\begin{array}{l}\text { Immigrant } \\
\text { households }\end{array}$ & $14.1 \%$ & $43.6 \%$ & $16.2 \%$ & $62.8 \%$ & $29.0 \%$ & $5.2 \%$ \\
\hline $\begin{array}{l}\text { Total } \\
\text { households }\end{array}$ & $\mathbf{4 , 3 2 7 , 0 0 0}$ & $39.8 \%$ & $13.0 \%$ & $67.3 \%$ & $29.0 \%$ \\
\hline $\begin{array}{l}\text { Immigrant } \\
\text { children }\end{array}$ & $20.7 \%$ & $35.6 \%$ & $10.8 \%$ & $69.7 \%$ & $25.1 \%$ & $2.4 \%$ \\
\hline $\begin{array}{l}\text { Total } \\
\text { children }\end{array}$ & $\mathbf{1 , 9 5 1 , 0 0 0}$ & $\mathbf{2 0 . 0 \%}$ & $\mathbf{5 . 6 \%}$ & $\mathbf{7 2 . 0 \%}$ & $\mathbf{1 3 . 0 \%}$ & $\mathbf{1 . 5 \%}$ \\
\hline
\end{tabular}

(Source: LIS 200O)

As in table 3.3 immigrant status is defined as households where the head or spouse is first generation immigrant without Swedish background, otherwise the content of the columns are identical to those explained in detail for New Zealand (table 4.2A).

Immigrant households in Sweden are consistently worse off than the total, but the difference is by no means vast, all the figures are in roughly the same magnitude, which could not be said of the New Zealand data - even when considering that the Swedish data is less refined in only using two categories where New Zealand has four groups. The difference is more noticeable when looking at child poverty. The fifth of children in Sweden with a parent with immigrant background are almost twice as likely to live in poverty, and those that do would need over 50 per cent more income increase to reach the poverty line compared to the average. Most of the differences are created by the market, but government intervention is still slightly less effective in alleviating poverty among immigrant household and children than among those without immigrant background. 


\subsection{Government intervention and family structure}

Section 3.3 demonstrated that household composition is an important predictor of market income poverty. Important parts of governments' redistributive efforts aim to reduce the risk of poverty for certain types of households. This section will look at how taxes and transfers affect the disposable income of various family types. Some of these policies affect not only poverty levels, but at times also affect family composition and related decisions in ways that are sometimes intended and at other times not. Section 4.1 suggests, for example, that fertility rates much below the replacement rate can be a negative externality. None of the three countries have particularly low fertility rates compared to the rest of the OECD, and this may in part be a result of government policies and thus an intended outcome. Former Norwegian Minister for children and equality, Karita Bekkemellem (2006), did for example warn against falling birth rates as a negative consequence of the Progress Party's suggested changes to family benefit policy. This shows that existing family and child benefits aims not only to alleviate poverty, but also to influence decisions as 'private' as birth rates. It is beyond the scope of this thesis to explore how policies affect the formation and aggregate composition of families. The composition of families will therefore be taken as given, and the focus will be on how family composition influences the government's redistribution and its' consequences for disposable income.

As in section 3.3, the first variable that will be discussed is the number of children. 
Table 4.3 A New Zealand household poverty by number of children

\begin{tabular}{|l|r|r|r|r|r|r|}
\hline & $\begin{array}{l}\text { Proportion of } \\
\text { households }\end{array}$ & $\begin{array}{l}\text { Market } \\
\text { income } \\
\text { poverty } \\
\text { rate }\end{array}$ & $\begin{array}{l}\text { Disposable } \\
\text { income } \\
\text { poverty rate }\end{array}$ & $\begin{array}{l}\text { Net } \\
\text { poverty } \\
\text { reduction }\end{array}$ & $\begin{array}{l}\text { Market } \\
\text { income } \\
\text { poverty } \\
\text { gap }\end{array}$ & $\begin{array}{l}\text { Disposable } \\
\text { income } \\
\text { poverty gap }\end{array}$ \\
\hline $\begin{array}{l}\text { No } \\
\text { children }\end{array}$ & $66.1 \%$ & $35.3 \%$ & $16.1 \%$ & $54.4 \%$ & $78.4 \%$ & $14.0 \%$ \\
\hline $\begin{array}{l}\text { One child } \\
\text { Two } \\
\text { children }\end{array}$ & $13.2 \%$ & $27.4 \%$ & $17.5 \%$ & $36.3 \%$ & $61.6 \%$ & $18.0 \%$ \\
\hline $\begin{array}{l}\text { Three } \\
\text { children }\end{array}$ & $13.5 \%$ & $24.9 \%$ & $22.4 \%$ & $10.0 \%$ & $66.7 \%$ & $18.0 \%$ \\
\hline $\begin{array}{l}\text { Four } \\
\text { children }\end{array}$ & $1.4 \%$ & $45.1 \%$ & $39.6 \%$ & $12.2 \%$ & $65.3 \%$ & $19 \% 0 \%$ \\
\hline $\begin{array}{l}\text { Five or } \\
\text { more } \\
\text { children }\end{array}$ & $0.6 \%$ & $75.8 \%$ & $52.2 \%$ & $31.2 \%$ & $75.5 \%$ & $23.0 \%$ \\
\hline $\begin{array}{l}\text { Total or } \\
\text { average }\end{array}$ & $\mathbf{1 , 3 7 4 , 1 5 2}$ & $\mathbf{3 2 . 7 \%}$ & $\mathbf{1 8 . 0 \%}$ & $\mathbf{4 5 . 0 \%}$ & $\mathbf{7 4 . 1 \%}$ & $\mathbf{1 5 . 6 \%}$ \\
\hline
\end{tabular}

(Source: New Zealand HES 2000/2001)

Table 4.3 $B$ Norwegian household poverty by number of children

\begin{tabular}{|c|c|c|c|c|c|c|}
\hline & $\begin{array}{l}\text { Proportion } \\
\text { of total }\end{array}$ & $\begin{array}{l}\text { Market } \\
\text { income } \\
\text { poverty } \\
\text { rate }\end{array}$ & $\begin{array}{l}\text { Disposable } \\
\text { income } \\
\text { poverty rate }\end{array}$ & $\begin{array}{l}\text { Net poverty } \\
\text { reduction }\end{array}$ & $\begin{array}{l}\text { Market } \\
\text { income } \\
\text { poverty } \\
\text { gap }\end{array}$ & $\begin{array}{l}\text { Disposable } \\
\text { income, } \\
\text { poverty gap }\end{array}$ \\
\hline $\begin{array}{l}\text { No } \\
\text { children }\end{array}$ & $72.0 \%$ & $43.6 \%$ & $23.2 \%$ & $46.8 \%$ & $30.6 \%$ & $6.3 \%$ \\
\hline One child & $12.1 \%$ & $19.9 \%$ & $7.8 \%$ & $60.8 \%$ & $12.1 \%$ & $1.9 \%$ \\
\hline $\begin{array}{l}\text { Two } \\
\text { children }\end{array}$ & $10.8 \%$ & $14.7 \%$ & $6.4 \%$ & $56.5 \%$ & $8.1 \%$ & $1.7 \%$ \\
\hline $\begin{array}{l}\text { Three } \\
\text { children }\end{array}$ & $4.3 \%$ & $12.6 \%$ & $5.6 \%$ & $55.6 \%$ & $6.1 \%$ & $1.4 \%$ \\
\hline $\begin{array}{l}\text { Four } \\
\text { children }\end{array}$ & $0.6 \%$ & $25.5 \%$ & $8.8 \%$ & $65.5 \%$ & $10.8 \%$ & $1.0 \%$ \\
\hline $\begin{array}{l}\text { Five or } \\
\text { more } \\
\text { children }\end{array}$ & $0.2 \%$ & $35.4 \%$ & $4.4 \%$ & $87.6 \%$ & $19.7 \%$ & $2.0 \%$ \\
\hline $\begin{array}{l}\text { Total or } \\
\text { average }\end{array}$ & $2,093,000$ & $36.1 \%$ & $18.6 \%$ & $48.5 \%$ & $24.8 \%$ & $5.0 \%$ \\
\hline
\end{tabular}

(Source: LIS 2000) 
Table 4.3C Swedish household poverty by number of children

\begin{tabular}{|c|c|c|c|c|c|c|}
\hline & $\begin{array}{l}\text { Proportion } \\
\text { of total }\end{array}$ & $\begin{array}{l}\text { Market } \\
\text { income } \\
\text { poverty } \\
\text { rate }\end{array}$ & $\begin{array}{l}\text { Disposable } \\
\text { income } \\
\text { poverty rate }\end{array}$ & $\begin{array}{l}\text { Net poverty } \\
\text { reduction }\end{array}$ & $\begin{array}{l}\text { Market } \\
\text { income } \\
\text { poverty } \\
\text { gap }\end{array}$ & $\begin{array}{l}\text { Disposable } \\
\text { income, } \\
\text { poverty gap }\end{array}$ \\
\hline $\begin{array}{l}\text { No } \\
\text { children }\end{array}$ & $75.1 \%$ & $46.7 \%$ & $15.4 \%$ & $67.0 \%$ & $34.5 \%$ & $5.1 \%$ \\
\hline One child & $10.3 \%$ & $20.0 \%$ & $6.6 \%$ & $67.0 \%$ & $13.4 \%$ & $2.0 \%$ \\
\hline $\begin{array}{l}\text { Two } \\
\text { children }\end{array}$ & $10.3 \%$ & $17.0 \%$ & $5.1 \%$ & $70.0 \%$ & $10.4 \%$ & $1.6 \%$ \\
\hline $\begin{array}{l}\text { Three } \\
\text { children }\end{array}$ & $3.3 \%$ & $18.0 \%$ & $5.1 \%$ & $71.7 \%$ & $11.1 \%$ & $1.2 \%$ \\
\hline $\begin{array}{l}\text { Four } \\
\text { children }\end{array}$ & $0.7 \%$ & $28.4 \%$ & $5.6 \%$ & $80.3 \%$ & $20.4 \%$ & $0.7 \%$ \\
\hline $\begin{array}{l}\text { Five or } \\
\text { more } \\
\text { children }\end{array}$ & $0.2 \%$ & $66.4 \%$ & $10.8 \%$ & $83.7 \%$ & $51.0 \%$ & $2.5 \%$ \\
\hline $\begin{array}{l}\text { Total or } \\
\text { average }\end{array}$ & $4,327,273$ & $39.8 \%$ & $13.0 \%$ & $67.3 \%$ & $29.0 \%$ & $4.2 \%$ \\
\hline
\end{tabular}

(Source: LIS 2OOO)

Columns number one, two and five in tables 4.3 contain mostly the same information as tables 3.4, except that in tables 4.3 the market income poverty rate is weighted by household rather than children, in order to make the measure of poverty reduction comparable. As in tables 4.2 the net poverty reduction refers to the proportion of households that are market income poor that have a disposable income above the poverty line. Taxes have a marginal impact on poverty in all groups in Scandinavia where data are available, especially the households with children, and the gross effect of taxes and transfers are thus not included in a separate column.

As discussed in section 3.3, the households without children are somewhat hard to compare in Scandinavia and New Zealand because a so large proportion of the poor are pensioners, and differences in the pension systems thus play a large role. Superannuation is counted as a benefit, while occupational pensions count as market income in all three countries. It seems like the New Zealand superannuation is less efficient in bringing elderly people out of poverty, but this need not be a fault of the superannuation scheme itself, it could just as well be a result of less efficient occupational pensions. The lower poverty rate and smaller poverty gap, and larger poverty reduction in Scandinavian households with no 
children should be seen in this context. Another problem with the New Zealand household data for the elderly is that the pension in many cases are just above the poverty line, which means that small changes in the pension or poverty line leads to large changes in poverty incidence in this group. Since the focus in this thesis is on child poverty, it falls beyond the scope to explore this question deeper. Focusing on the households with children it becomes clear that in New Zealand and Norway both the market income poverty rate and the poverty reduction rate has a U-shape when it comes to the number of children. In New Zealand households with 2 children has the lowest poverty rate, 3 in Norway. Transfers seem to be far more directed to one-child households in New Zealand however, so poverty rates are consistently rising with the number of children. Poverty reduction rates are both higher and more evenly distributed in both the Scandinavian countries. In Sweden the rate of poverty reduction is steadily increasing with the number of children, but disposable income poverty rates and poverty depth in the very large families (five or more children) are still almost twice of those in the smaller households. This does of course affect only a very small number of households.

As shown in section 3.3, the number of adults in a household is in some ways more important than the number of children. 
Table 4.4 A New Zealand household poverty by family type

\begin{tabular}{|c|c|c|c|c|c|c|}
\hline & $\begin{array}{l}\text { Proportion } \\
\text { of } \\
\text { households }\end{array}$ & $\begin{array}{l}\text { Market } \\
\text { income } \\
\text { poverty } \\
\text { rate }\end{array}$ & $\begin{array}{l}\text { Disposable } \\
\text { income } \\
\text { poverty rate }\end{array}$ & $\begin{array}{l}\text { Net poverty } \\
\text { reduction }\end{array}$ & $\begin{array}{l}\text { Market } \\
\text { income } \\
\text { poverty } \\
\text { gap }\end{array}$ & $\begin{array}{l}\text { Disposable } \\
\text { income, } \\
\text { poverty gap }\end{array}$ \\
\hline 1 adult & $23.4 \%$ & $54.3 \%$ & $26.8 \%$ & $50.6 \%$ & $83.7 \%$ & $12 \%$ \\
\hline $\begin{array}{l}1 \text { adult, } \\
1 \text { or more } \\
\text { child }\end{array}$ & $5.1 \%$ & $78.4 \%$ & $64.7 \%$ & $17.5 \%$ & $74.1 \%$ & $17 \%$ \\
\hline 2 adults & $30.3 \%$ & $30.7 \%$ & $12.4 \%$ & $59.6 \%$ & $73.8 \%$ & $14 \%$ \\
\hline $\begin{array}{l}2 \text { adults, } \\
1 \text { child }\end{array}$ & $6.2 \%$ & $19.1 \%$ & $11.1 \%$ & $41.9 \%$ & $57.0 \%$ & $21 \%$ \\
\hline $\begin{array}{l}2 \text { adults, } \\
2 \text { children }\end{array}$ & $9.6 \%$ & $16.5 \%$ & $16.1 \%$ & $2.4 \%$ & $57.3 \%$ & $20 \%$ \\
\hline $\begin{array}{l}2 \text { adults, } \\
3 \text { or more } \\
\text { children }\end{array}$ & $5.0 \%$ & $21.4 \%$ & $19.3 \%$ & $9.8 \%$ & $43.0 \%$ & $18 \%$ \\
\hline $\begin{array}{l}3 \text { or more } \\
\text { adults }\end{array}$ & $12.5 \%$ & $11.1 \%$ & $5.2 \%$ & $53.2 \%$ & $60.5 \%$ & $26 \%$ \\
\hline $\begin{array}{l}3 \text { or more } \\
\text { adults, } \\
1 \text { or more } \\
\text { children }\end{array}$ & $8.1 \%$ & $19.8 \%$ & $11.1 \%$ & $43.9 \%$ & $60.4 \%$ & $18 \%$ \\
\hline $\begin{array}{ll}\text { Total or } \\
\text { average }\end{array}$ & $1,374,152$ & $32.7 \%$ & $18.0 \%$ & $45.0 \%$ & $74.1 \%$ & $15.6 \%$ \\
\hline
\end{tabular}

(Source: New Zealand HES 2000/2001) 
Table $4.4 B$ Norwegian household poverty by family type

\begin{tabular}{|c|c|c|c|c|c|c|}
\hline & $\begin{array}{l}\text { Proportion } \\
\text { of total }\end{array}$ & $\begin{array}{l}\text { Market } \\
\text { income } \\
\text { poverty } \\
\text { rate }\end{array}$ & $\begin{array}{l}\text { Disposable } \\
\text { income } \\
\text { poverty rate }\end{array}$ & $\begin{array}{l}\text { Net poverty } \\
\text { reduction }\end{array}$ & $\begin{array}{l}\text { Market } \\
\text { income } \\
\text { poverty } \\
\text { gap }\end{array}$ & $\begin{array}{l}\text { Disposable } \\
\text { income, } \\
\text { poverty gap }\end{array}$ \\
\hline 1 adult & $41.3 \%$ & $54.5 \%$ & $36.3 \%$ & $33.4 \%$ & $40.2 \%$ & $10.0 \%$ \\
\hline $\begin{array}{l}1 \text { adult } 1 \\
\text { or more } \\
\text { child }\end{array}$ & $5.3 \%$ & $55.9 \%$ & $21.4 \%$ & $61.7 \%$ & $35.9 \%$ & $5.5 \%$ \\
\hline 2 adults & $25.1 \%$ & $33.5 \%$ & $6.6 \%$ & $80.3 \%$ & $20.7 \%$ & $1.4 \%$ \\
\hline $\begin{array}{l}2 \text { adults } 1 \\
\text { child }\end{array}$ & $6.4 \%$ & $7.6 \%$ & $3.5 \%$ & $53.9 \%$ & $3.4 \%$ & $0.7 \%$ \\
\hline $\begin{array}{l}2 \text { adults } 2 \\
\text { children }\end{array}$ & $8.4 \%$ & $7.2 \%$ & $3.7 \%$ & $48.6 \%$ & $3.4 \%$ & $0.8 \%$ \\
\hline $\begin{array}{l}2 \text { adults } 3 \\
\text { Or more } \\
\text { children }\end{array}$ & $4.4 \%$ & $10.8 \%$ & $4.7 \%$ & $56.5 \%$ & $4.6 \%$ & $1.3 \%$ \\
\hline $\begin{array}{l}3 \text { or more } \\
\text { adults }\end{array}$ & $5.6 \%$ & $8.5 \%$ & $1.1 \%$ & $87.1 \%$ & $4.5 \%$ & $1.1 \%$ \\
\hline $\begin{array}{l}3 \text { or more } \\
\text { adults } \\
1 \text { or more } \\
\text { children }\end{array}$ & $3.5 \%$ & $6.4 \%$ & $1.6 \%$ & $75.0 \%$ & $2.6 \%$ & $0.7 \%$ \\
\hline $\begin{array}{l}\text { Total or } \\
\text { average }\end{array}$ & $2,093,000$ & $36.1 \%$ & $18.6 \%$ & $48.5 \%$ & $24.8 \%$ & $5.0 \%$ \\
\hline
\end{tabular}

(Source: LIS 2000)

Tables 4.4 show that in all three countries, out of the households with children, the disposable income poverty rate was substantially higher among those with only one adult. The highest poverty reduction rate was found in large families (i.e. those with two adults and three or more children, and three adults with children) in Sweden, where more than three out of four poor households are brought above the poverty line by transfers. It is worth noting that occupants of many small households may have been pensioners, and looking ahead to tables 4.7 it is found that the Scandinavian countries had a higher poverty reduction rate among elderly. The highest market income poverty rate in household types with children is found among the single adult households in New Zealand where nearly four out of five households are poor, presumably because of low labour participation among sole parents. Nonetheless, the poverty reduction here is far from being the most effective. 
Table 4.4 C Swedish household poverty by family type

\begin{tabular}{|c|c|c|c|c|c|c|}
\hline & 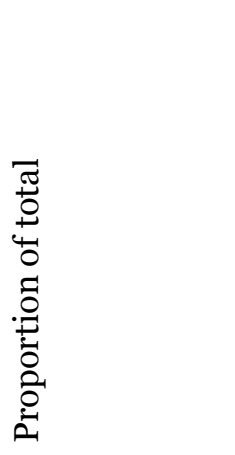 & 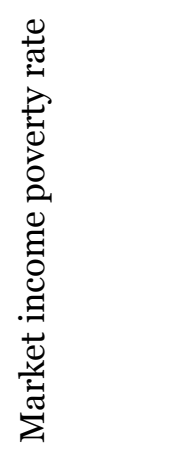 & 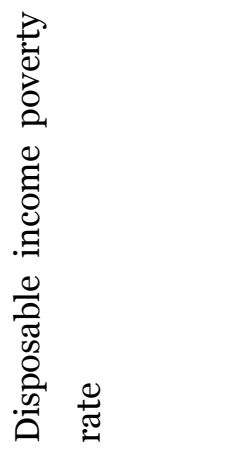 & 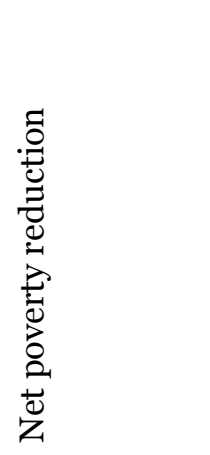 & 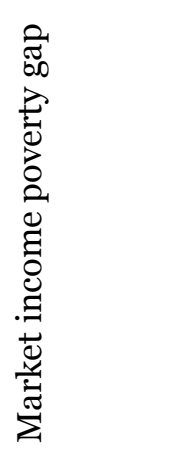 & 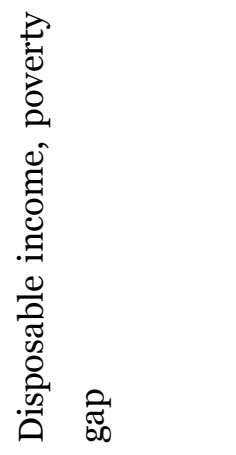 \\
\hline 1 adult & $46.4 \%$ & $55.6 \%$ & $22.7 \%$ & $59.2 \%$ & $42.9 \%$ & $7.5 \%$ \\
\hline $\begin{array}{l}1 \text { adult } 1 \text { or } \\
\text { more child }\end{array}$ & $5.3 \%$ & $49.3 \%$ & $14.4 \%$ & $70.8 \%$ & $34.1 \%$ & $3.5 \%$ \\
\hline 2 adults & $25.0 \%$ & $35.8 \%$ & $3.9 \%$ & $89.1 \%$ & $23.4 \%$ & $1.4 \%$ \\
\hline $\begin{array}{ll}2 \text { adults } 1 \\
\text { child }\end{array}$ & $5.8 \%$ & $10.9 \%$ & $3.7 \%$ & $66.1 \%$ & $6.1 \%$ & $1.3 \%$ \\
\hline $\begin{array}{l}2 \text { adults } 2 \\
\text { children }\end{array}$ & $7.9 \%$ & $10.3 \%$ & $3.7 \%$ & $64.1 \%$ & $6.2 \%$ & $1.4 \%$ \\
\hline $\begin{array}{l}2 \text { adults } 3 \\
\text { Or more } \\
\text { children }\end{array}$ & $3.4 \%$ & $15.7 \%$ & $3.7 \%$ & $76.4 \%$ & $9.7 \%$ & $0.9 \%$ \\
\hline $\begin{array}{l}3 \text { or more } \\
\text { adults }\end{array}$ & $3.7 \%$ & $7.9 \%$ & $1.7 \%$ & $78.5 \%$ & $4.4 \%$ & $0.8 \%$ \\
\hline $\begin{array}{l}3 \text { or more } \\
\text { adults } \\
1 \text { or more } \\
\text { children }\end{array}$ & $2.6 \%$ & $7.7 \%$ & $1.8 \%$ & $76.6 \%$ & $4.7 \%$ & $0.6 \%$ \\
\hline $\begin{array}{l}\text { Total or } \\
\text { average }\end{array}$ & $4,327,273$ & $39.8 \%$ & $13.0 \%$ & $67.3 \%$ & $29.0 \%$ & $4.2 \%$ \\
\hline
\end{tabular}

(Source: LIS 200O)

In Norway and Sweden, where the single adult household with children are also vulnerable to market income poverty relative to other household types with children, the poverty reduction from transfers is more extensive than in households with two adults (which also have very low market income poverty rates), but lower than in households with three adults. This is also the case in New Zealand except that the households with two adults and only one child also have a remarkably high poverty reduction rate. 
Table 4.5 A New Zealand child poverty by family type

\begin{tabular}{|c|c|c|c|c|c|c|}
\hline & 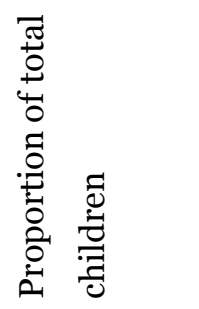 & 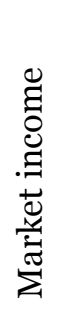 & 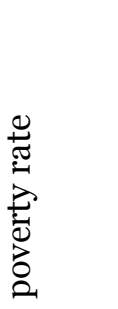 & 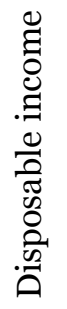 & 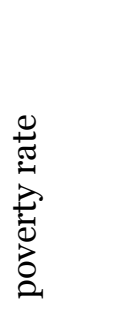 & 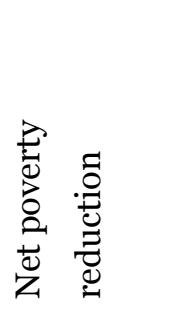 \\
\hline 1 adult, 1 or more child & $14.2 \%$ & & $83.6 \%$ & & $71.6 \%$ & $14.4 \%$ \\
\hline 2 adults, 1 child & $9.6 \%$ & & $19.1 \%$ & & $11.1 \%$ & $41.9 \%$ \\
\hline 2 adults, 2 children & $29.6 \%$ & & $16.5 \%$ & & $16.1 \%$ & $2.1 \%$ \\
\hline 2 adults, 3 or more children & $25.3 \%$ & & $23.3 \%$ & & $20.7 \%$ & $10.8 \%$ \\
\hline 3 or more adults, 1 or more children & $21.4 \%$ & & $25.7 \%$ & & $14.4 \%$ & $43.9 \%$ \\
\hline Total or average & 886,000 & & $29.9 \%$ & & $24.3 \%$ & $18.7 \%$ \\
\hline
\end{tabular}

(Source: New Zealand HES 2000/2001)

Tables 4.5 give the same figures as tables 4.4 , but with data weighted by the number of children. The Norwegian and Swedish data on poverty depth are weighted by number of children in the household in tables 4.5. Table 4.5A does not contain measures of poverty depth, because the New Zealand dataset lacks a measure for these variables weighted by children.

\section{Table $4.5 B$ Norwegian child poverty by family type}

\begin{tabular}{|c|c|c|c|c|c|c|}
\hline & 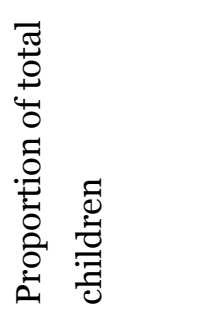 & 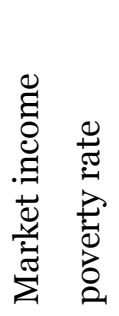 & 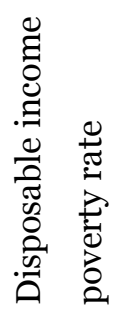 & 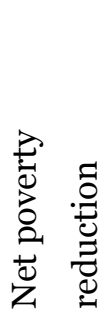 & 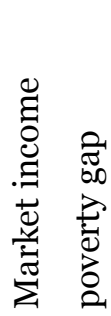 & 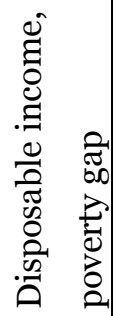 \\
\hline 1 adult, 1 or more child & $15.2 \%$ & $58.7 \%$ & $22.2 \%$ & $62.2 \%$ & $37.1 \%$ & $5.7 \%$ \\
\hline 2 adults, 1 child & $12.8 \%$ & $7.6 \%$ & $3.5 \%$ & $53.9 \%$ & $3.4 \%$ & $.7 \%$ \\
\hline 2 adults, 2 children & $33.5 \%$ & $7.2 \%$ & $3.7 \%$ & $48.6 \%$ & $3.4 \%$ & $.9 \%$ \\
\hline 2 adults, 3 or more children & $28.2 \%$ & $12.1 \%$ & $4.9 \%$ & $59.5 \%$ & $5.2 \%$ & $1.3 \%$ \\
\hline $\begin{array}{l}3 \text { or more adults, } \\
1 \text { or more children }\end{array}$ & $10.4 \%$ & $7.3 \%$ & $1.7 \%$ & $76.7 \%$ & $3.1 \%$ & $.6 \%$ \\
\hline Total or average & $1,051,000$ & $16.4 \%$ & $6.6 \%$ & $59.8 \%$ & $9.0 \%$ & $1.7 \%$ \\
\hline
\end{tabular}

(Source: LIS 200O)

Sweden had the highest proportion of children living with one adult, New Zealand had the lowest, and Sweden also had the highest poverty reduction rate in this group of children, New Zealand had the lowest. The disposable income child 
poverty rate of 71.6 per cent was the only group in the family type tables that was above 50 per cent. While the market income poverty rate was also high in this group, the poverty reduction rate was lower than the average in New Zealand, and this rate was less than a third than the Norwegian equivalent.

Table 4.5 C Swedish child poverty by family type

\begin{tabular}{|c|c|c|c|c|c|c|}
\hline & 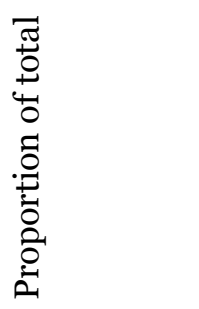 & 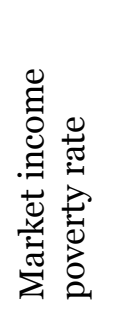 & 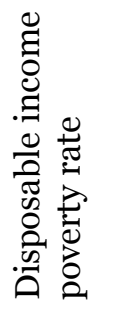 & 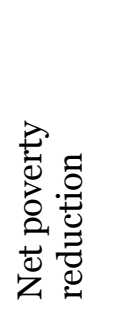 & 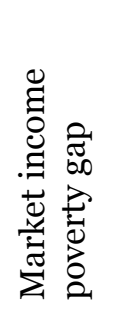 & 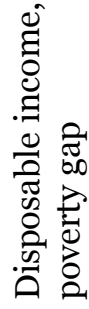 \\
\hline 1 adult, 1 or more child & $19.1 \%$ & $51.2 \%$ & $14.3 \%$ & $72.1 \%$ & $35.6 \%$ & $3.1 \%$ \\
\hline 2 adults, 1 child & $12.9 \%$ & $10.9 \%$ & $3.7 \%$ & $66.1 \%$ & $6.1 \%$ & $1.3 \%$ \\
\hline 2 adults, 2 children & $35.1 \%$ & $10.3 \%$ & $3.7 \%$ & $64.1 \%$ & $6.2 \%$ & $1.4 \%$ \\
\hline $\begin{array}{l}2 \text { adults, } 3 \\
\text { Or more children }\end{array}$ & $24.5 \%$ & $17.7 \%$ & $3.8 \%$ & $78.5 \%$ & $11.1 \%$ & $0.9 \%$ \\
\hline $\begin{array}{l}3 \text { or more adults, } \\
1 \text { or more children }\end{array}$ & $8.5 \%$ & $9.6 \%$ & $1.9 \%$ & $80.2 \%$ & $5.7 \%$ & $0.6 \%$ \\
\hline Total or average & $1,951,000$ & $20.0 \%$ & $5.6 \%$ & $72.0 \%$ & $13.0 \%$ & $1.5 \%$ \\
\hline
\end{tabular}

(Source: LIS 200O)

Table $4.6 \mathrm{~A}$ New Zealand poverty rates by household head age

\begin{tabular}{|c|c|c|c|c|c|c|c|c|}
\hline 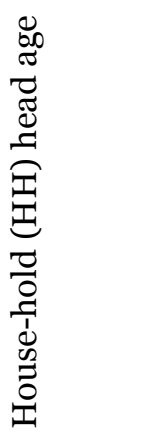 & 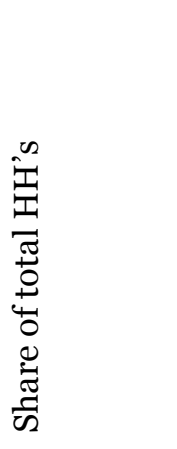 & 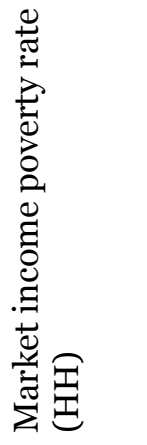 & 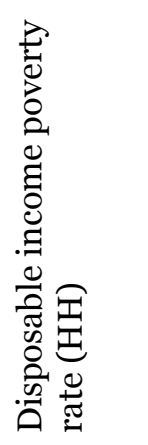 & 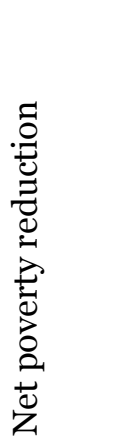 & 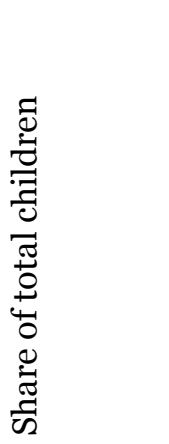 & 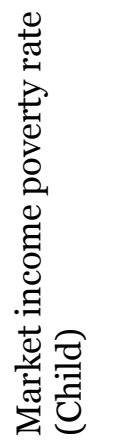 & 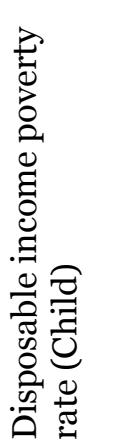 & 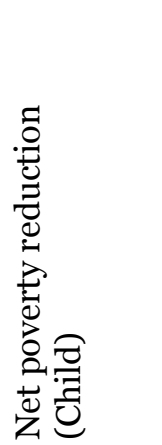 \\
\hline $15-24$ & $5.5 \%$ & $34.5 \%$ & $28.2 \%$ & $18.3 \%$ & $4.0 \%$ & $55.1 \%$ & $45.8 \%$ & $16.9 \%$ \\
\hline $25-29$ & $7.5 \%$ & $26.9 \%$ & $21.1 \%$ & $21.6 \%$ & $10.5 \%$ & $48.7 \%$ & $35.6 \%$ & $26.9 \%$ \\
\hline $30-39$ & $21.8 \%$ & $18.3 \%$ & $16.0 \%$ & $12.6 \%$ & $45.7 \%$ & $28.2 \%$ & $25.5 \%$ & $9.6 \%$ \\
\hline $40-49$ & $20.8 \%$ & $16.2 \%$ & $13.2 \%$ & $18.5 \%$ & $30.6 \%$ & $22.5 \%$ & $17.7 \%$ & $21.3 \%$ \\
\hline $50-59$ & $18.4 \%$ & $20.0 \div$ & $15.4 \%$ & $23.0 \%$ & $8.2 \%$ & $25.8 \%$ & $20.5 \%$ & $20.5 \%$ \\
\hline $60-64$ & $5.9 \%$ & $39.5 \%$ & $18.2 \%$ & $53.9 \%$ & $.2 \%$ & $70.8 \%$ & * & - \\
\hline $65^{+}$ & $20.1 \%$ & $77.0 \div$ & $23.6 \%$ & $69.4 \%$ & $.8 \%$ & $72.0 \%$ & * & - \\
\hline $\begin{array}{l}\text { Total or } \\
\text { averaqe }\end{array}$ & $1,374,000$ & $32.7 \%$ & $18.0 \%$ & $45.0 \%$ & 886,000 & $29.9 \%$ & $24.3 \%$ & $18.7 \%$ \\
\hline
\end{tabular}

(Source: New Zealand HES 200O/2001; * insufficient data) 
Table $4.6 B$ Norwegian poverty rates by household head age

\begin{tabular}{|c|c|c|c|c|c|c|c|c|}
\hline $\begin{array}{l}\text { House- } \\
\text { hold } \\
(\mathrm{HH}) \\
\text { head age }\end{array}$ & $\begin{array}{l}\text { Share of } \\
\text { total } \\
\text { HH's }\end{array}$ & $\begin{array}{l}\text { Market } \\
\text { income } \\
\text { poverty } \\
\text { rate } \\
(\mathrm{HH})\end{array}$ & $\begin{array}{l}\text { Dispos- } \\
\text { able } \\
\text { income } \\
\text { poverty } \\
\text { rate } \\
(\mathrm{HH})\end{array}$ & $\begin{array}{l}\text { Net } \\
\text { poverty } \\
\text { red- } \\
\text { uction }\end{array}$ & $\begin{array}{l}\text { Share of } \\
\text { total } \\
\text { children }\end{array}$ & $\begin{array}{l}\text { Market } \\
\text { income } \\
\text { poverty } \\
\text { rate } \\
\text { (Child) }\end{array}$ & $\begin{array}{l}\text { Dispos- } \\
\text { able } \\
\text { income } \\
\text { poverty } \\
\text { rate } \\
\text { (Child) }\end{array}$ & $\begin{array}{l}\text { Net } \\
\text { poverty } \\
\text { reduction } \\
\text { (Child) }\end{array}$ \\
\hline $15-24$ & $6.6 \%$ & $60.1 \%$ & $57.6 \%$ & $4.2 \%$ & $1.6 \%$ & $61.9 \%$ & $18.3 \%$ & $70.4 \%$ \\
\hline $25-29$ & $9.0 \%$ & $26.6 \%$ & $20.3 \%$ & $23.7 \%$ & $7.8 \%$ & $31.0 \%$ & $13.1 \%$ & $57.7 \%$ \\
\hline $30-39$ & $19.5 \%$ & $18.0 \%$ & $9.6 \%$ & $46.7 \%$ & $45.0 \%$ & $19.3 \%$ & $7.7 \%$ & $60.1 \%$ \\
\hline $40-49$ & $18.3 \%$ & $13.4 \%$ & $6.5 \%$ & $51.5 \%$ & $37.9 \%$ & $9.0 \%$ & $4.1 \%$ & $54.4 \%$ \\
\hline $50-59$ & $16.6 \%$ & $16.1 \%$ & $6.8 \%$ & $57.8 \%$ & $7.1 \%$ & $11.6 \%$ & $3.8 \%$ & $67.2 \frac{\circ}{\circ}$ \\
\hline $60-64$ & $5.3 \%$ & $31.3 \%$ & $13.6 \%$ & $56.5 \%$ & $0.4 \%$ & $11.9 \%$ & $7.9 \%$ & $33.6 \%$ \\
\hline $65^{+}$ & $24.7 \%$ & $78.9 \%$ & $32.7 \%$ & $58.6 \%$ & $0.2 \%$ & $40.0 \%$ & * & - \\
\hline $\begin{array}{l}\text { Total or } \\
\text { average }\end{array}$ & $2,093,000$ & $36.1 \%$ & $18.6 \%$ & $48.5 \%$ & $1,051,000$ & $16.4 \%$ & $6.6 \%$ & $59.8 \%$ \\
\hline
\end{tabular}

(Source: LIS 2000; ${ }^{*}=$ insufficient data)

Tables 4.6 show that the poverty reduction in Scandinavian households gradually increases along with increases in age, while in New Zealand the poverty reduction is relatively stable until the household head reaches the age of 60 . The high market poverty rate among young people, particularly in Scandinavia, probably reflects that this age group contain many students. That students are poor is less concerning than it would be for most other groups, as they can be expected to increase their income when they enter the labour market, and the poverty situation is highly likely to be only temporary. The situation in New Zealand is rather distinct with its' lower market poverty for young household heads, which is particularly important because the population also is younger on average. New Zealand has a larger group of children living with younger parents and this group has higher market poverty rates. These two observations would both support a hypothesis suggesting that they finish studies younger or study less. Poverty reduction weighted by children is higher in Scandinavia and the group of children living with a household head aged below 30 is under 10 per cent. With those caveats it still seems that government efforts to reduce poverty in this group are more successful in Norway than in Sweden. In New Zealand there is no clear pattern. 
Table 4.6 C Swedish poverty rates by household head age

\begin{tabular}{|c|c|c|c|c|c|c|c|c|}
\hline $\begin{array}{l}\text { House- } \\
\text { hold } \\
(\mathrm{HH}) \\
\text { head age }\end{array}$ & $\begin{array}{l}\text { Share of } \\
\text { total } \\
\text { HH's }\end{array}$ & $\begin{array}{l}\text { Market } \\
\text { income } \\
\text { poverty } \\
\text { rate } \\
(\mathrm{HH})\end{array}$ & $\begin{array}{l}\text { Dispos- } \\
\text { able } \\
\text { income } \\
\text { poverty } \\
\text { rate } \\
(\mathrm{HH})\end{array}$ & $\begin{array}{l}\text { Net } \\
\text { poverty } \\
\text { red- } \\
\text { uction }\end{array}$ & $\begin{array}{l}\text { Share of } \\
\text { total } \\
\text { children }\end{array}$ & $\begin{array}{l}\text { Market } \\
\text { income } \\
\text { poverty } \\
\text { rate } \\
\text { (Child) }\end{array}$ & $\begin{array}{l}\text { Dispos- } \\
\text { able } \\
\text { income } \\
\text { poverty } \\
\text { rate } \\
\text { (Child) }\end{array}$ & $\begin{array}{l}\text { Net } \\
\text { poverty } \\
\text { reduction } \\
\text { (Child) }\end{array}$ \\
\hline $15-24$ & $6.9 \%$ & $55.2 \%$ & $53.3 \%$ & $3.4 \%$ & $1.2 \%$ & $59.3 \%$ & $44.0 \%$ & $25.8 \%$ \\
\hline $25-29$ & $8.3 \%$ & $27.0 \%$ & $20.4 \%$ & $24.4 \%$ & $6.2 \%$ & $36.6 \%$ & $12.9 \%$ & $64.8 \%$ \\
\hline $30-39$ & $18.1 \%$ & $22.5 \%$ & $7.9 \%$ & $64.9 \%$ & $44.2 \%$ & $23.0 \%$ & $6.0 \%$ & $73.9 \%$ \\
\hline $40-49$ & $17.5 \%$ & $18.4 \%$ & $5.8 \%$ & $68.5 \%$ & $38.9 \%$ & $14.0 \%$ & $3.4 \%$ & $75.7 \%$ \\
\hline $50-59$ & $18.2 \%$ & $17.6 \%$ & $4.2 \%$ & $76.1 \%$ & $8.9 \%$ & $12.8 \%$ & $2.2 \%$ & $82.8 \%$ \\
\hline $60-64$ & $6.2 \%$ & $32.3 \%$ & $5.1 \%$ & $84.2 \%$ & $0.4 \%$ & $31.6 \%$ & $11.5 \%$ & $63.6 \%$ \\
\hline $65^{+}$ & $24.8 \%$ & $85.8 \%$ & $16.6 \%$ & $80.7 \%$ & $0.2 \%$ & $41.2 \%$ & $10.3 \%$ & $75.0 \%$ \\
\hline $\begin{array}{l}\text { Total or } \\
\text { average }\end{array}$ & $4,327,273$ & $39.8 \%$ & $13.0 \%$ & $67.3 \%$ & $1,951,000$ & $20.0 \%$ & $5.6 \%$ & $72.0 \%$ \\
\hline
\end{tabular}

(Source: LIS 2000)

Table $4.7 A$ New Zealand poverty rates by people over 60

\begin{tabular}{|l|l|l|l|l|l|l|l|l|}
\hline $\begin{array}{l}\text { Number } \\
\text { of people } \\
\text { over 6o } \\
\text { years old } \\
\text { in HH }\end{array}$ & $\begin{array}{l}\text { total } \\
\text { HH's }\end{array}$ & $\begin{array}{l}\text { Market } \\
\text { income } \\
\text { poverty } \\
\text { rate } \\
\text { (HH) }\end{array}$ & $\begin{array}{l}\text { Dispos- } \\
\text { able } \\
\text { income } \\
\text { poverty } \\
\text { rate } \\
\text { (HH) }\end{array}$ & $\begin{array}{l}\text { Net } \\
\text { poverty } \\
\text { red- } \\
\text { uction }\end{array}$ & $\begin{array}{l}\text { Share of } \\
\text { total } \\
\text { children }\end{array}$ & $\begin{array}{l}\text { Market } \\
\text { income } \\
\text { poverty } \\
\text { rate } \\
\text { (Child) }\end{array}$ & $\begin{array}{l}\text { Dispos- } \\
\text { able } \\
\text { income } \\
\text { poverty } \\
\text { rate } \\
\text { (Child) }\end{array}$ & $\begin{array}{l}\text { Net } \\
\text { poverty } \\
\text { reduction } \\
\text { (Child) }\end{array}$ \\
\hline O & $70.3 \%$ & $19.6 \%$ & $17.0 \%$ & $13.3 \%$ & $95.6 \%$ & $29.1 \%$ & $25.2 \%$ & $13.4 \%$ \\
\hline $\mathbf{1}$ or more & $18.7 \%$ & $65.0 \%$ & $23.3 \%$ & $64.2 \%$ & $2.1 \%$ & $51.7 \%$ & $8.2 \%$ & $84.1 \%$ \\
\hline $\begin{array}{l}11.0 \% \\
\text { or more }\end{array}$ & $29.7 \%$ & $63.8 \%$ & $20.4 \%$ & $68.0 \%$ & $4.4 \%$ & $49.2 \%$ & $3.9 \%$ & $92.1 \%$ \\
\hline $\begin{array}{l}\text { Total or } \\
\text { average }\end{array}$ & $\mathbf{1 , 3 7 4 , 0 0 0}$ & $\mathbf{3 2 . 7 \%}$ & $\mathbf{1 8 . 0 \%}$ & $\mathbf{4 5 . 0 \%}$ & 886,000 & $\mathbf{2 9 . 9} \%$ & $\mathbf{2 4 . 3 \%}$ & $\mathbf{1 8 . 7 \%}$ \\
\hline
\end{tabular}

(Source: New Zealand HES 2000/2001; * = insufficient data) 
Table $4.7 B$ Norwegian poverty rates by people over 64

\begin{tabular}{|l|l|l|l|l|l|l|l|l|}
\hline $\begin{array}{l}\text { Number } \\
\text { of people } \\
\text { over } 60 \\
\text { years old } \\
\text { in HH }\end{array}$ & $\begin{array}{l}\text { total } \\
\text { HH's }\end{array}$ & $\begin{array}{l}\text { Market } \\
\text { income } \\
\text { poverty } \\
\text { rate } \\
(\mathrm{HH})\end{array}$ & $\begin{array}{l}\text { Dispos- } \\
\text { able } \\
\text { income } \\
\text { poverty } \\
\text { rate } \\
(\mathrm{HH})\end{array}$ & $\begin{array}{l}\text { Net } \\
\text { poverty } \\
\text { red- } \\
\text { uction }\end{array}$ & $\begin{array}{l}\text { Share of } \\
\text { total } \\
\text { child-ren }\end{array}$ & $\begin{array}{l}\text { Market } \\
\text { income } \\
\text { poverty } \\
\text { rate } \\
\text { (Child) }\end{array}$ & $\begin{array}{l}\text { Dispos- } \\
\text { able } \\
\text { income } \\
\text { poverty } \\
\text { rate } \\
\text { (Child) }\end{array}$ & $\begin{array}{l}\text { Net } \\
\text { poverty } \\
\text { reduction } \\
\text { (Child) }\end{array}$ \\
\hline O & $74.7 \%$ & $22.0 \%$ & $14.1 \%$ & $35.9 \%$ & $99.5 \%$ & $16.4 \%$ & $6.6 \%$ & $59.8 \%$ \\
\hline $\begin{array}{l}\mathbf{2} \text { or } \\
\text { more }\end{array}$ & $17.9 \%$ & $78.3 \%$ & $41.6 \%$ & $46.9 \%$ & $0.4 \%$ & $49.4 \%$ & $13.2 \%$ & $73.3 \%$ \\
\hline $\begin{array}{l}1 \text { or more } \\
\text { Total or } \\
\text { average }\end{array}$ & $25.3 \%$ & $77.0 \%$ & $8.8 \%$ & $88.6 \%$ & $0.1 \%$ & $\star$ & $*$ & $\star$ \\
\hline
\end{tabular}

(Source: LIS 2000; * ${ }^{*}$ insufficient data)

The household data in tables 4.7 are a particularly useful addition to the rest of the household poverty reduction data. Note that, as in section 3.3, the age threshold used is 60 in New Zealand and 64 in Norway and Sweden. It clearly shows that Sweden has a very high market poverty rate among the elderly, and that almost all of this is removed by government transfers, resulting in Sweden having the lowest disposable income poverty. Also among the households without anyone over 64 the poverty reduction is more extensive in Sweden than the two other countries. For every row in these tables the market income poverty rate is higher in Norway than in New Zealand, but lower than in Sweden. The New Zealand government's poverty reduction benefits the elderly more than in Norway where poverty reduction is more effective among households without anyone over 64 . This finding is consistent with the finding that child poverty reduction is more successful in Scandinavia. The findings should be seen in light of the caveat from section 3.3 regarding classification of pensions as market and disposable income. 
Table 4.7 C Swedish poverty rates by people over 64

\begin{tabular}{|c|c|c|c|c|c|c|c|c|}
\hline 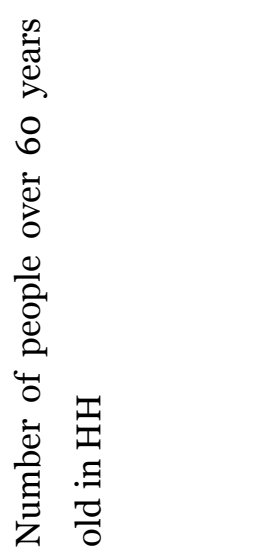 & 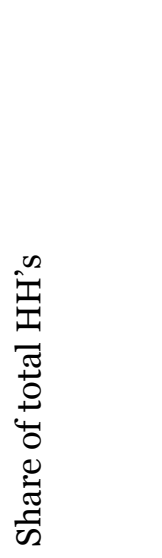 & 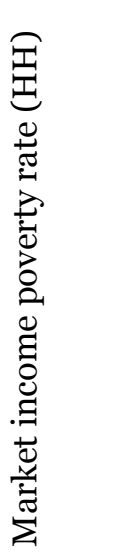 & 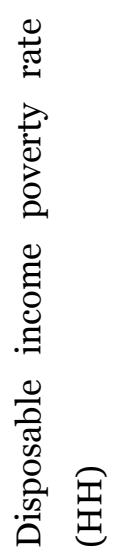 & 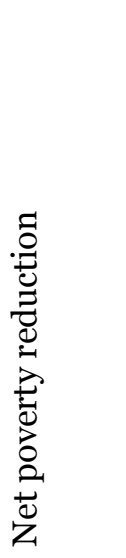 & 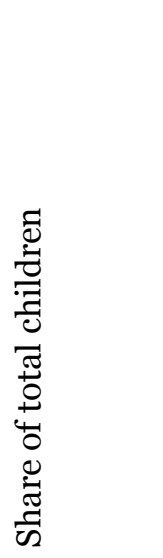 & 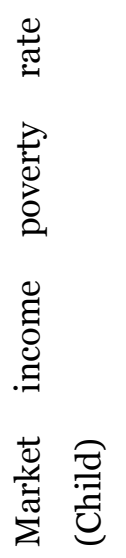 & 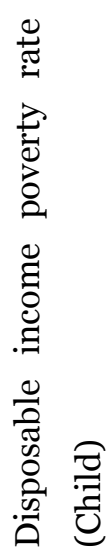 & 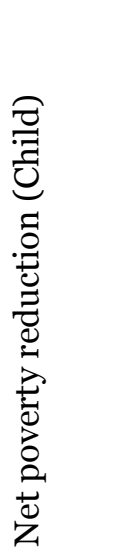 \\
\hline 0 & $73.7 \%$ & $24.6 \%$ & $12.0 \%$ & $51.2 \%$ & $99.6 \%$ & $19.9 \%$ & $5.6 \%$ & $71.9 \%$ \\
\hline 1 & $18.7 \%$ & $82.7 \%$ & $20.9 \%$ & $74.7 \%$ & $0.4 \%$ & $35.3 \%$ & $4.9 \%$ & $86.1 \%$ \\
\hline 2 or more & $7.7 \%$ & $81.7 \%$ & $2.9 \%$ & $96.5 \%$ & $0.0 \%$ & * & $0.0 \%$ & - \\
\hline 1 or more & $26.3 \%$ & $82.4 \%$ & $15.7 \%$ & $80.9 \%$ & $0.4 \%$ & $36.4 \%$ & $4.8 \%$ & $86.8 \%$ \\
\hline Total or average & $2,093,000$ & $36.1 \%$ & $18.6 \%$ & $48.5 \%$ & $1,051,000$ & $16.4 \%$ & $6.6 \%$ & $59.8 \%$ \\
\hline
\end{tabular}

(Source: LIS 2000) 


\subsection{Government intervention and education attainment}

As shown in section 3.5 there is an extensive literature discussing how education affects market income. How government policies to relieve poverty affect people with different levels of education attainment is a much less researched question. Evaluations of broad labour market policy may consider how returns to education and inequality as such are affected, but policies to relieve poverty are seldom considered in the light of education attainment. This is in part because education-driven differences in disposable poverty can primarily be traced back to higher market income among the higher educated. It is also worth noting that education is seen as a long-term solution of poverty rather than a short term way of alleviating poverty, in the same way as entry into the labour market. Education can facilitate entry into the labour market, and reduce the risk of poverty in other ways (e.g. through better health and lower risk of crime), either way it has a long term effect. Some government spending and some kind of benefits are designed to encourage education and entry into the labour market. The analysis here is also somewhat incomplete, as education was not included in the New Zealand survey, and the Swedish data are suffering from missing data. 
Table 4.8 A Norwegian poverty rates by head's or spouse's highest education attainment

\begin{tabular}{|c|c|c|c|c|c|c|c|c|}
\hline & 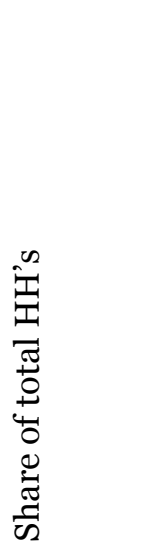 & 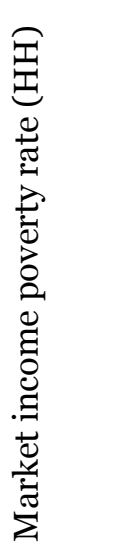 & 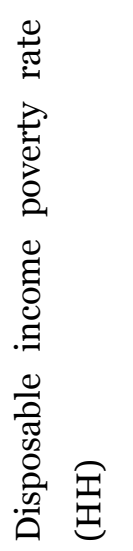 & 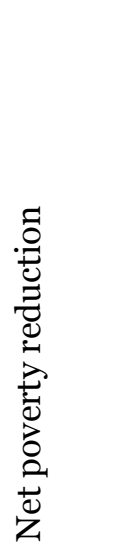 & 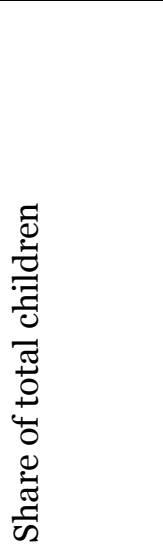 & 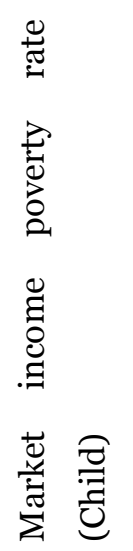 & 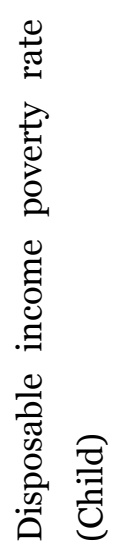 & 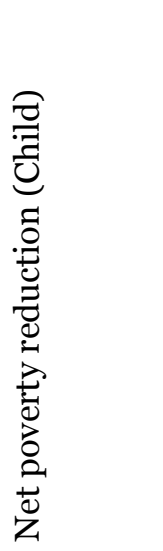 \\
\hline Primary & $18.4 \%$ & $73.8 \%$ & $17.9 \%$ & $75.7 \%$ & $3.4 \%$ & $52.3 \%$ & $24.5 \%$ & $53.2 \%$ \\
\hline $\begin{array}{l}\text { Lower } \\
\text { secondary }\end{array}$ & $26.4 \%$ & $43.5 \%$ & $14.0 \%$ & $67.8 \%$ & $20.5 \%$ & $33.9 \%$ & $11.7 \%$ & $65.5 \%$ \\
\hline $\begin{array}{l}\text { Upper } \\
\text { secondary }\end{array}$ & $23.1 \%$ & $23.8 \%$ & $14.0 \%$ & $41.2 \%$ & $30.2 \%$ & $14.0 \%$ & $5.2 \%$ & $62.9 \%$ \\
\hline $\begin{array}{l}\text { Post- } \\
\text { secondary, } \\
\text { non-tertiary }\end{array}$ & $2.7 \%$ & $18.0 \%$ & $7.7 \%$ & $57.2 \%$ & $4.1 \%$ & $8.9 \%$ & $5.9 \%$ & $33.7 \%$ \\
\hline $\begin{array}{l}\text { Lower } \\
\text { tertiary }\end{array}$ & $21.1 \%$ & $17.2 \%$ & $10.0 \%$ & $41.9 \%$ & $29.3 \%$ & $6.4 \%$ & $2.6 \%$ & $59.4 \%$ \\
\hline $\begin{array}{l}\text { Upper } \\
\text { tertiary }\end{array}$ & $6.6 \%$ & $7.5 \%$ & $2.5 \%$ & $66.7 \%$ & $10.7 \%$ & $2.0 \%$ & $1.6 \%$ & $20.0 \%$ \\
\hline $\begin{array}{l}\text { Total or } \\
\text { average }\end{array}$ & $2,093,000$ & $36.1 \%$ & $18.6 \%$ & $48.5 \%$ & $1,051,000$ & $16.4 \%$ & $6.6 \%$ & $59.8 \%$ \\
\hline
\end{tabular}

(Source: LIS 200O) 
Table 4.8 B Swedish poverty rates by head's or spouse's highest education attainment

\begin{tabular}{|c|c|c|c|c|c|c|c|c|}
\hline & 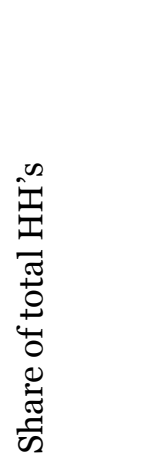 & 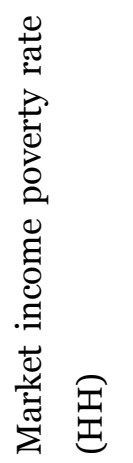 & 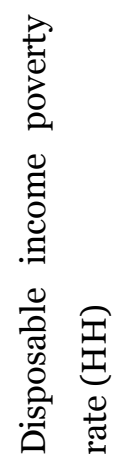 & 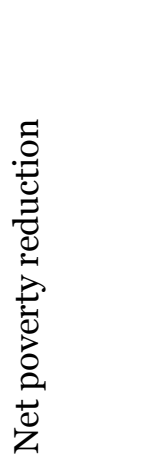 & 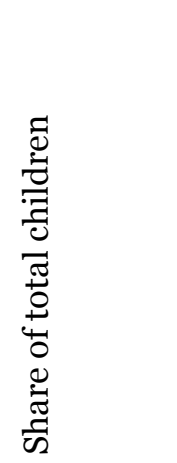 & 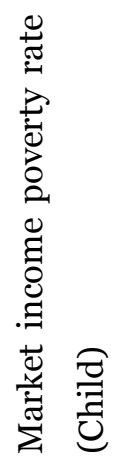 & 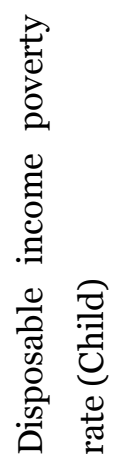 & 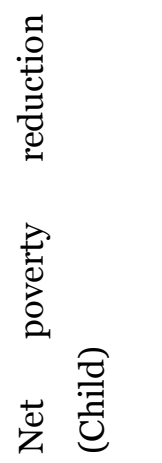 \\
\hline Primary & $9.3 \%$ & $68.2 \%$ & $87.6 \%$ & $-28.4 \%$ & $1.4 \%$ & $74.7 \%$ & $20.2 \%$ & $73.0 \%$ \\
\hline $\begin{array}{l}\text { Lower } \\
\text { secondary }\end{array}$ & $7.2 \%$ & $48.6 \%$ & $78.3 \%$ & $-61.1 \%$ & $6.4 \%$ & $53.3 \%$ & $13.9 \%$ & $73.9 \%$ \\
\hline $\begin{array}{l}\text { Upper } \\
\text { secondary }\end{array}$ & $40.7 \%$ & $29.5 \%$ & $9.1 \%$ & $69.2 \%$ & $49.4 \%$ & $21.0 \%$ & $5.3 \%$ & $74.8 \%$ \\
\hline $\begin{array}{l}\text { Post- } \\
\text { secondary, } \\
\text { non- } \\
\text { tertiary }\end{array}$ & $5.2 \%$ & $32.6 \%$ & $25.8 \%$ & $20.9 \%$ & $6.6 \%$ & $15.0 \%$ & $5.3 \%$ & $64.7 \%$ \\
\hline $\begin{array}{l}\text { Lower } \\
\text { tertiary }\end{array}$ & $23.2 \%$ & $16.1 \%$ & $8.1 \%$ & $49.7 \%$ & $34.0 \%$ & $9.7 \%$ & $3.3 \%$ & $66.0 \%$ \\
\hline $\begin{array}{l}\text { Upper } \\
\text { tertiary }\end{array}$ & $0.9 \%$ & $5.3 \%$ & * & - & $1.2 \%$ & * & * & - \\
\hline Missing & $12.7 \%$ & $93.2 \%$ & $23.7 \%$ & $74.6 \%$ & $0.0 \%$ & $74.7 \%$ & $20.2 \%$ & $73.0 \%$ \\
\hline $\begin{array}{l}\text { Total or } \\
\text { average }\end{array}$ & $4,327,000$ & $39.8 \%$ & $13.0 \%$ & $67.3 \%$ & $1,951,000$ & $20.0 \%$ & $5.6 \%$ & $72.0 \%$ \\
\hline
\end{tabular}

(Source: LIS 2000; * ${ }^{*}$ insufficient data)

The Swedish missing data do not appear to be randomly distributed, possibly because of age factors, and must therefore be interpreted with due caution. The distribution of education attainment below upper secondary education compared to Norway suggests that if the distribution was similar to that in Norway, the households where education data are missing were disproportionally from the households with low levels of education attainment. Coupled with the high poverty reduction among the household with missing education data would explain the increase in poverty caused by taxes among households with low education attainment in Sweden compared to Norway.

Despite this caveat the data make a handful of interesting observations stand out. The relationship between poverty and education attainment appears to be firmly correlated in that increase in education leads to lower poverty in nearly all the categories, both market and income, household and child poverty in both countries, with the occasional exception of the small post secondary, non-tertiary category. 
Secondly, the relationship between household poverty reduction and child poverty reduction is virtually unrelated. The poverty reduction is systematically lower for child poverty than household poverty in each education category. In Norway, where data are more reliable, the poverty reduction in households does not show a clear pattern, while in both countries the proportional child poverty reduction was gradually decreasing with higher education attainment. 


\subsection{Government intervention and income source}

Table 4.9 A New Zealand poverty rates by income source and employment status

\begin{tabular}{|c|c|c|c|c|c|c|c|c|}
\hline & 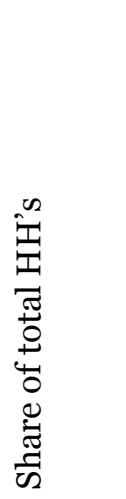 & 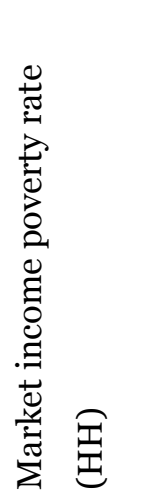 & 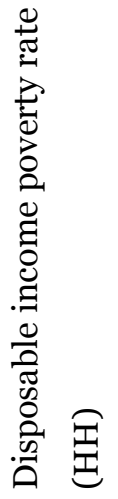 & 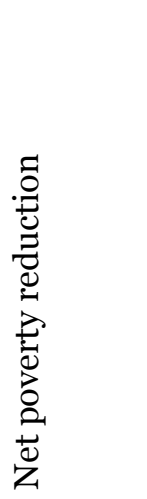 & 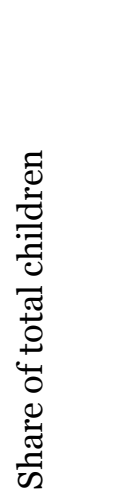 & 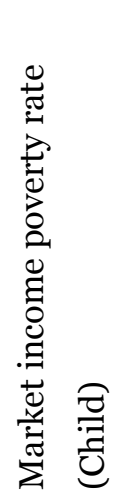 & 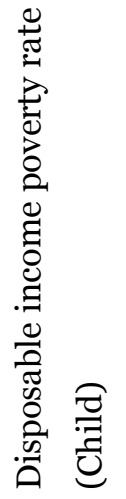 & 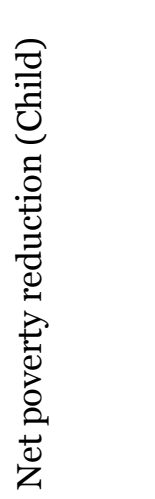 \\
\hline $\begin{array}{l}\text { Majority } \\
\text { income } \\
\text { from } \\
\text { benefits }\end{array}$ & $18.8 \%$ & $100.0 \%$ & $54.1 \%$ & $45.9 \%$ & $12.5 \%$ & $100 \%$ & $81.1 \%$ & $18.9 \%$ \\
\hline $\begin{array}{l}\text { Some } \\
\text { income } \\
\text { from } \\
\text { benefits }\end{array}$ & $15.1 \%$ & $57.6 \%$ & $20.8 \%$ & $63.9 \%$ & $12.1 \%$ & $63.1 \%$ & $41.6 \%$ & $34.0 \%$ \\
\hline $\begin{array}{l}1 \text { adult no } \\
\text { benefit } \\
\text { income }\end{array}$ & $22.4 \%$ & $16.9 \%$ & $12.5 \%$ & $26.0 \%$ & $23.6 \%$ & $31.1 \%$ & $26.6 \%$ & $14.5 \%$ \\
\hline $\begin{array}{l}2 \text { adult no } \\
\text { benefit } \\
\text { income }\end{array}$ & $32.3 \%$ & $3.7 \%$ & $4.8 \%$ & $-29.7 \%$ & $42.9 \%$ & $5.6 \%$ & $6.5 \%$ & $-16.2 \%$ \\
\hline $\begin{array}{l}3 \text { adult no } \\
\text { benefit } \\
\text { income }\end{array}$ & $11.4 \%$ & $2.1 \%$ & $2.9 \%$ & $-38.1 \%$ & $9.0 \%$ & $1.3 \%$ & $1.3 \%$ & $0.0 \%$ \\
\hline $\begin{array}{l}\text { Total in } \\
\text { thousand } \\
\text { s or } \\
\text { average }\end{array}$ & 1,374 & $32.7 \%$ & $18.0 \%$ & $45.0 \%$ & 886 & $29.9 \%$ & $24.3 \%$ & $18.7 \%$ \\
\hline
\end{tabular}

(Source: New Zealand HES 2000/2001) 
Table 4.9 B Norwegian poverty rates by income source and employment status

\begin{tabular}{|c|c|c|c|c|c|c|c|c|}
\hline & 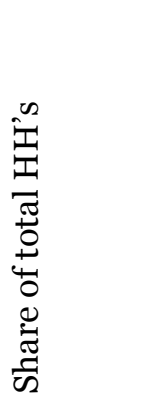 & 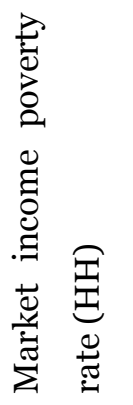 & 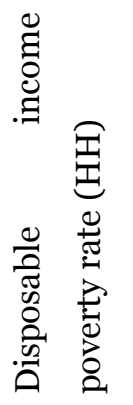 & 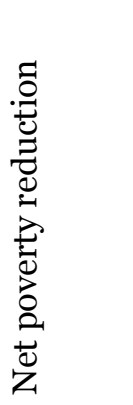 & 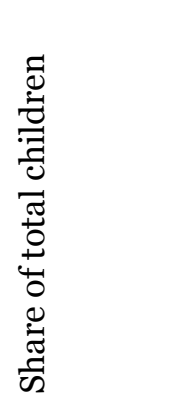 & 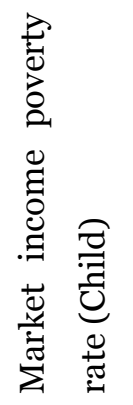 & 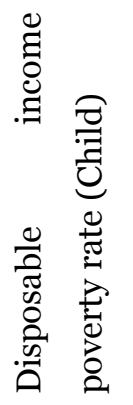 & 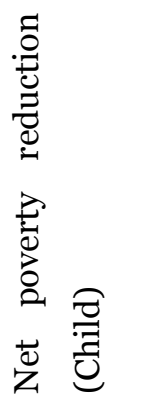 \\
\hline $\begin{array}{l}\text { Main income } \\
\text { from benefit }\end{array}$ & $36.0 \%$ & $87.9 \%$ & $43.6 \%$ & $50.4 \%$ & $8.6 \%$ & $94.2 \%$ & $44.5 \%$ & $52.8 \%$ \\
\hline $\begin{array}{l}\text { Head or } \\
\text { spouse main } \\
\text { income from } \\
\text { employment }\end{array}$ & $36.8 \%$ & $11.9 \%$ & $7.7 \%$ & $35.3 \%$ & $32.2 \%$ & $24.2 \%$ & $7.8 \%$ & $67.8 \%$ \\
\hline $\begin{array}{l}\text { Head and } \\
\text { spouse main } \\
\text { income from } \\
\text { employment }\end{array}$ & $27.2 \%$ & $0.5 \%$ & $0.4 \%$ & $20.0 \%$ & $59.3 \%$ & $1.0 \%$ & $0.5 \%$ & $50.0 \%$ \\
\hline $\begin{array}{ll}\text { Total } & \text { or } \\
\text { average }\end{array}$ & $2,093,000$ & $36.1 \%$ & $18.6 \%$ & $48.5 \%$ & $1,051,000$ & $16.4 \%$ & $6.6 \%$ & $59.8 \%$ \\
\hline
\end{tabular}

(Source: LIS 200O)

The net increase of poverty among households with two or three adults but no benefit income as a result of taxes in New Zealand was strikingly absent in Norway and Sweden. Even the gross increase in household poverty rate from taxes33was below 2.5 per cent of total households in Norway and below 1.5 per cent in Sweden for all groups (not shown in table). However, the market poverty rate was also markedly lower, and New Zealand is one of the few countries where tax is charged from the first dollars earned, and this may have been a major factor in explaining the negative effect for the group that did not receive any benefits in New Zealand. As shown in table 4.1 this affected 1 per cent of all households in Norway and 0.6 per cent of Swedish households. In both Scandinavian countries this affected mostly the households with employment income from either head or spouse (presumably mostly single adult households), while the phenomenon were less common (but existent) among households that had two adults in employment or had their income mainly from benefits. In the three countries studied here the correlation between tax rates and proportion of households that are brought below the poverty line by taxes was in other words negative. The highest total tax rate (measured as a

\footnotetext{
${ }^{33}$ I.e. the proportion of the total number of households that had a disposable income below the poverty line despite having a market income that was above the poverty line.
} 
share of GDP) was found in Sweden (see figure 4.1), but hardly any households were brought into poverty by this tax burden.

The tax level in Norway was slightly lower, but the tax burden nonetheless brought a larger proportion into poverty. The New Zealand data do not provide gross figures for poverty reduction, but looking at the increase in poverty rate from market income to disposable income among the households that didn't receive benefits, at least .45 per cent 34 of all households were taxed into poverty when only looking at the two last categories. Among the 18.8 per cent of households with their majority income from benefits, none had a market income above the poverty line, so none of these may have been adversely affected by taxes. Among the 37.5 per cent that either had one employed adult or some benefit income, the disposable poverty were more widespread, so potentially the total effect of taxes on bringing households into poverty could be several times larger than the 0.45 per cent in the last two categories, even though the New Zealand had the lowest tax take of the three countries. This shows that the effect of taxes on poverty potentially depends more on the tax system and the distribution of the tax burden than the tax rates per se. Regardless, as was pointed out in section 4.1, the effect is marginal compared to the effect that transfers can have in reducing poverty.

\footnotetext{
${ }^{34}$ This is based on the following calculation: in non-beneficiary households with two adults $4.8 \%-3.1 \%=1.1 \%$ out of the $32.3 \%$ of the total households $(32.3 \% \times 1.1 \%=0.36 \%)$ were brought into poverty by the tax burden, and adding the $2.9 \%-2.1 \%=0.8 \%$ of the $11.4 \%$ of the non-beneficiary households with three adults gives $.09 \%$ to a total of $0.45 \%$ of the total households.
} 
Table 4.9 C Swedish poverty rates by income source and employment status

\begin{tabular}{|c|c|c|c|c|c|c|c|c|}
\hline & 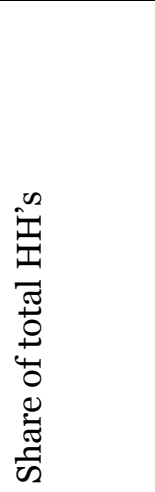 & 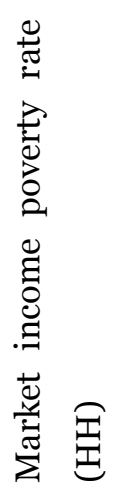 & 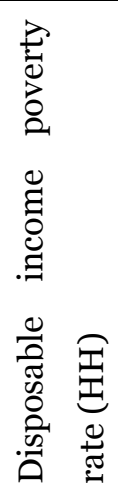 & 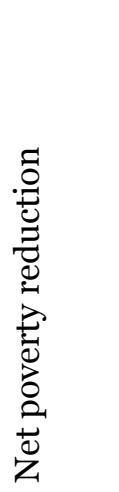 & 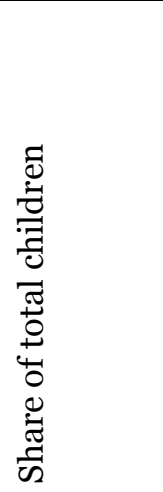 & 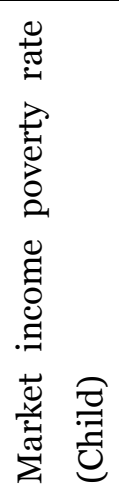 & 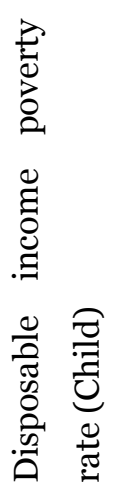 & 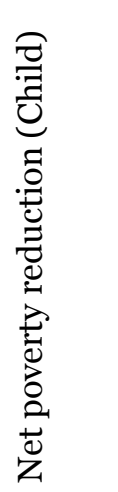 \\
\hline $\begin{array}{l}\text { Main income } \\
\text { from benefit }\end{array}$ & $34.3 \%$ & $91.1 \%$ & $26.5 \%$ & $70.9 \%$ & $7.2 \%$ & $98.1 \%$ & $34.1 \%$ & $65.2 \%$ \\
\hline $\begin{array}{lr}\text { Head } & \text { or } \\
\text { spouse main } \\
\text { income from } \\
\text { employment }\end{array}$ & $37.0 \%$ & $20.8 \%$ & $9.7 \%$ & $53.4 \%$ & $27.0 \%$ & $36.5 \%$ & $8.5 \%$ & $76.7 \%$ \\
\hline $\begin{array}{l}\text { Head and } \\
\text { spouse main } \\
\text { income from } \\
\text { employment }\end{array}$ & $28.7 \%$ & $3.1 \%$ & $1.2 \%$ & $61.3 \%$ & $65.8 \%$ & $4.6 \%$ & $1.3 \%$ & $71.7 \%$ \\
\hline $\begin{array}{ll}\text { Total } & \text { or } \\
\text { average } & \end{array}$ & $4,327,273$ & $39.8 \%$ & $13.0 \%$ & $67.3 \%$ & $1,951,000$ & $20.0 \%$ & $5.6 \%$ & $72.0 \%$ \\
\hline
\end{tabular}

(Source: LIS 2000) 


\subsection{Interaction effects in disposable income poverty}

In this section the same analyses as in section 3.8 will be done on disposable income. As in the rest of chapter four, the difference from chapter three is that this chapter deals with actually disposable income, rather than market income. In other words this chapter says something about living standards, and the difference in poverty levels between these two chapters describes how successful the government's taxes and benefits was at reducing poverty. This difference could have been described separately as well, but at some point the level of detail must be limited, and this is where the line is drawn in this thesis. As in section 3.8 it will not be speculated in what the causes for the interaction effects may have been (as the in the dataset employed here would provide limited empirical evidence for such speculation), the purpose of the chapter is to show that a more detailed description of demographic groups can explain more of the difference in poverty levels, and also to shed some light on the strength of this effect compared to the effects on market income. As already explained the New Zealand dataset attained for this thesis does not allow this particular analysis, so it will unfortunately be limited to Norway and Sweden.

As in section 3.8 the first group whose poverty rate is to be examined is the children and households with one adult who is 30 years old or younger. Recall that in Norway the total disposable poverty rate was $18.7 \%$ for households and $6.6 \%$ for children. Figures for Sweden were 13.0\% and 5.6\%.

The findings in table 4.10 demonstrate that the findings from the first table of section 3.8 holds for disposable poverty as well as market poverty, namely that children and households that has a young and single adult are more likely to be poor than those who live with one adult aged over 30 and those who live with two or more adults aged 30 or under. The child poverty reduction rate35 (not in table) in Norway is similar for all groups in the table; in Sweden the rate is lowest for the young and single group but only marginally lower than for the 30 or under group.

\footnotetext{
${ }^{35}$ I.e. the fraction of the market poor that are brought out of poverty by taxes and benefit.
} 
Table 4.1O Poverty in young parent and one-adult households

\begin{tabular}{|l|l|l|l|l|}
\hline Household type & $\begin{array}{l}\text { Household } \\
\text { Incidence }\end{array}$ & $\begin{array}{l}\text { Share of } \\
\text { children }\end{array}$ & $\begin{array}{l}\text { Household } \\
\text { poverty }\end{array}$ & $\begin{array}{l}\text { Child } \\
\text { poverty }\end{array}$ \\
\hline \multicolumn{5}{|c|}{ Norway } \\
\hline $\begin{array}{l}\text { All households where the head is } 30 \\
\text { or younger }\end{array}$ & $15.6 \%$ & $9.4 \%$ & $36.0 \%$ & $14.0 \%$ \\
\hline All households with only one adult & $46.6 \%$ & $15.2 \%$ & $34.6 \%$ & $22.2 \%$ \\
\hline $\begin{array}{l}\text { Households with only one adult } \\
\text { where the head is 30 or younger }\end{array}$ & $11.1 \%$ & $2.7 \%$ & $47.1 \%$ & $34.4 \%$ \\
\hline \multicolumn{5}{|c|}{ Sweden } \\
\hline $\begin{array}{l}\text { All households where the head is 30 } \\
\text { or younger }\end{array}$ & $15.2 \%$ & $7.4 \%$ & $35.3 \%$ & $18.0 \%$ \\
\hline All households with only one adult & $51.7 \%$ & $19.1 \%$ & $21.8 \%$ & $14.3 \%$ \\
\hline $\begin{array}{l}\text { Households with only one adult } \\
\text { where the head is 30 or younger }\end{array}$ & $11.3 \%$ & $2.2 \%$ & $43.7 \%$ & $38.6 \%$ \\
\hline
\end{tabular}

Table 4.11 Poverty in one-adult HHs with three or more children

\begin{tabular}{|l|l|l|l|l|}
\hline Household type & $\begin{array}{l}\text { Household } \\
\text { Incidence }\end{array}$ & $\begin{array}{l}\text { Share of } \\
\text { children }\end{array}$ & $\begin{array}{l}\text { Household } \\
\text { poverty }\end{array}$ & $\begin{array}{l}\text { Child } \\
\text { poverty }\end{array}$ \\
\hline \multicolumn{5}{|c|}{ Norway } \\
\hline $\begin{array}{l}\text { All households with three or more } \\
\text { children }\end{array}$ & $5.1 \%$ & $32.8 \%$ & $5.9 \%$ & $6.0 \%$ \\
\hline All households with only one adult & $46.6 \%$ & $15.2 \%$ & $34.6 \%$ & $22.2 \%$ \\
\hline $\begin{array}{l}\text { Households with only one adult and } \\
\text { three or more children }\end{array}$ & $0.2 \%$ & $2.7 \%$ & $15.8 \%$ & $38.6 \%$ \\
\hline \multicolumn{5}{|c|}{ Sweden } \\
\hline $\begin{array}{l}\text { All households with three or more } \\
\text { children }\end{array}$ & $4.3 \%$ & $31.3 \%$ & $5.5 \%$ & $5.6 \%$ \\
\hline All households with only one adult & $51.7 \%$ & $19.1 \%$ & $21.8 \%$ & $14.3 \%$ \\
\hline $\begin{array}{l}\text { Households with only one adult and } \\
\text { three or more children }\end{array}$ & $0.7 \%$ & $5.0 \%$ & $23.7 \%$ & $22.7 \%$ \\
\hline
\end{tabular}

Table 4.11 shows much the same information as table 4.10 , but focuses on households with one adult and three or more children. In the number of households this group was far less common than the group described in table 4.10, but a larger fraction of children lived in this sort of household. Again, the findings show that the subgroup was more exposed to poverty than any of entire groups separately.

In this group the two groups fare quite differently in the two countries: Even though Sweden's overall reduction in child poverty through taxes and transfers are large, the reduction in child poverty is relatively low, notably when compared to Norway. Again, the reduction rate is found when comparing the data from the tables here in chapter 4 with the market poverty rates from chapter 3 . The difference between the countries is caused by a combination of higher disposable income poverty in Sweden, and higher market poverty in Norway. 
Table 4.12 Poverty in one-adult, immigrant households

\begin{tabular}{|l|l|l|l|l|}
\hline Household type & $\begin{array}{l}\text { Household } \\
\text { Incidence }\end{array}$ & $\begin{array}{l}\text { Share of } \\
\text { children }\end{array}$ & $\begin{array}{l}\text { Household } \\
\text { poverty }\end{array}$ & $\begin{array}{l}\text { Child } \\
\text { poverty }\end{array}$ \\
\hline \multicolumn{5}{|c|}{ Norway } \\
\hline All households with only one adult & $46.6 \%$ & $15.2 \%$ & $34.6 \%$ & $22.2 \%$ \\
\hline All immigrant households & $7.9 \%$ & $11.8 \%$ & $25.6 \%$ & $15.5 \%$ \\
\hline $\begin{array}{l}\text { Immigrant households with only } \\
\text { one adult }\end{array}$ & $3.0 \%$ & $1.5 \%$ & $31.9 \%$ \\
\hline \multicolumn{7}{|c|}{ Sweden } & $21.8 \%$ & $14.3 \%$ \\
\hline All households with only one adult & $51.7 \%$ & $19.1 \%$ & $16.2 \%$ & $26.8 \%$ \\
\hline All immigrant households & $14.1 \%$ & $20.7 \%$ & $27.5 \%$ & $\circ \%$ \\
\hline $\begin{array}{l}\text { Immigrant households with only } \\
\text { one adult }\end{array}$ & $6.2 \%$ & $3.4 \%$ & $\circ$ \\
\hline
\end{tabular}

Among households with only one adult, if that household had some immigrant background the risk of being poor was substantially higher. This was yet another case where the children in a vulnerable group are particularly exposed to poverty.

Table 4.13 Poverty in immigrant HHs with three or more children

\begin{tabular}{|l|l|l|l|l|}
\hline Household type & $\begin{array}{l}\text { Household } \\
\text { Incidence }\end{array}$ & $\begin{array}{l}\text { Share of } \\
\text { children }\end{array}$ & $\begin{array}{l}\text { Household } \\
\text { poverty }\end{array}$ & $\begin{array}{l}\text { Child } \\
\text { poverty }\end{array}$ \\
\hline \multicolumn{5}{|c|}{ Norway } \\
\hline $\begin{array}{l}\text { All households with three or more } \\
\text { children }\end{array}$ & $5.1 \%$ & $32.8 \%$ & $5.9 \%$ & $6.0 \%$ \\
\hline All immigrant households & $7.9 \%$ & $11.8 \%$ & $25.6 \%$ & $15.5 \%$ \\
\hline $\begin{array}{l}\text { Immigrant households with three } \\
\text { or more children }\end{array}$ & $0.6 \%$ & $4.2 \%$ & $17.0 \%$ & $16.9 \%$ \\
\hline \multicolumn{2}{|l|}{ Sweden } & $31.3 \%$ & $5.5 \%$ & $5.6 \%$ \\
\hline $\begin{array}{l}\text { All households with three or more } \\
\text { children }\end{array}$ & $4.3 \%$ & $20.7 \%$ & $16.2 \%$ & $10.8 \%$ \\
\hline All immigrant households & $14.1 \%$ & $12.1 \%$ & $12.8 \%$ \\
\hline $\begin{array}{l}\text { Immigrant households with three } \\
\text { or more children }\end{array}$ & $1.0 \%$ & $7.7 \%$ & \\
\hline
\end{tabular}

Table 4.13 confirms the finding from section 3.8, that immigrant households with children are in fact better off than other immigrant households, but that immigrant children are better off if the number of children in the household is one or two. This factor is small compared to the immigrant factor itself when compared to the child poverty rates in the entire population. In Sweden, the poverty reduction rate in immigrant households three or more children is nearly as high as that for all households with three or more children, in Norway the rate for immigrant households is significantly lower than for the entire group. This largely explains why having immigrant background is a more negative factor for households with many children in Norway than in Sweden. 
This section has, like section 3.8, not attempted to explain why these combinations of factors lead to higher poverty rate. Again the purpose of the section is to demonstrate that this interaction-effect is just as important when looking at disposable income as it is for market income. It has also shown how this interaction effect can influence effect of government intervention. Even though it was argued at length earlier in the chapter for why government intervention benefits the poor most, this section has shown that there is little reason to assume that groups that are particularly vulnerable to poverty are more likely to be helped by government intervention than other poor groups. The charitable, but pessimistic interpretation of this is that that this shows how hard it is to make universalist government interventions aid those most in need. A more optimistic view would be to say that the findings show that there is room for improvements. 


\section{Counterfactual analysis}

Chapter 4 focused on the effect of government income redistribution on poverty within various groups in the three countries introduced in chapter 3 where the focus was on market income distribution. This separation is chosen because the main aim of this thesis is to say something about how much child poverty a government can be expected to eradicate, and how much the levels of child poverty depends on market income and the demographic composition. That analysis is done in this chapter, by exploring what the child poverty levels in New Zealand would have been if government intervention had brought the same proportion of poor in various groups out of poverty as is done in Norway and Sweden, and by asking what poverty levels would have been in Norway and Sweden if those countries had New Zealand's demographic composition or market income poverty levels. This should make it easier to discern to what extent it is possible for a government to eradicate child poverty through policy reforms, and to what extent variations in child poverty across countries is explained by demographic and other factors beyond the reach of policymakers. If the counterfactual analysis of Scandinavian increases poverty rates by 'imagining' that Norway and Sweden have New Zealand's market poverty rates and demographic composition that would suggest that factors that it is difficult for policymakers to change are the most important explanations. Conversely, the extent to which New Zealand's poverty rate is reduced when the rate at which Scandinavian (market) poverty rate is reduced by transfers and taxes is 'imagined' implemented would suggest that policies can make a difference despite more or less favourable demographic and market poverty conditions. 


\subsection{Overall household and child poverty level analysis}

It would, of course, be too simplistic to assume that any policy model found in Norway or Sweden could simply be implemented in a country on the other side of the earth such as New Zealand. And if reality was so simple that the complexities of income redistribution policies could be expressed in one percentage figure, that would put many social scientists out of work.

Notwithstanding these points, the percentage of households and children that are lifted above the poverty line by government intervention does say something about the priority given to poverty eradication by the respective governments. It is worth noting, though, that what is counted as government intervention here gives a limited picture of the scope of policies that can potentially reduce poverty; only the most direct ways of influencing households' income are included. Minimum wage legislation can, for example influence the income available to low income working households, without being noticed in the figure discussed here. Although the distributive impact of such indirect policies may be significant, it does not seem to be a miracle cure. Studying the extent to which this figure varies across countries and the extent to which it has a decisive impact on poverty measured in disposable income, should therefore give some indication about the degree to which it is possible for governments to alleviate poverty.

Table 5.1 New Zealand household and child poverty rates with Scandinavian rates of poverty reduction

\begin{tabular}{|c|c|c|c|c|c|c|c|}
\hline & 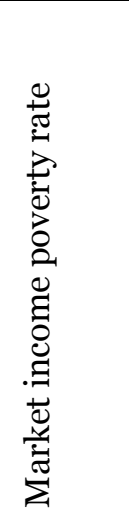 & 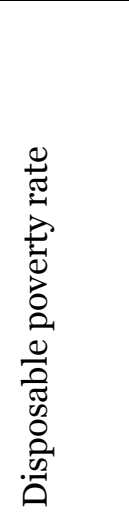 & 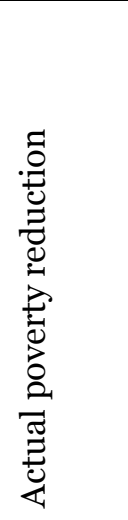 & 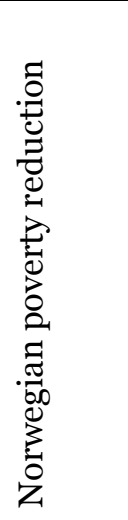 & 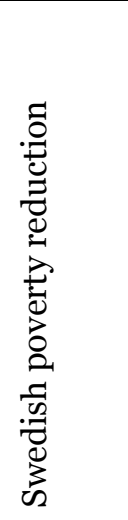 & 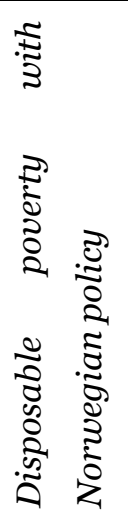 & 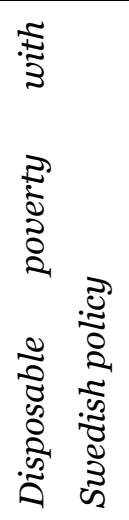 \\
\hline Households & $32.7 \%$ & $18.0 \%$ & $45.0 \%$ & $48.5 \%$ & $67.3 \%$ & $16.8 \%$ & $10.7 \%$ \\
\hline Children & $29.9 \%$ & $24.3 \%$ & $18.7 \%$ & $59.8 \%$ & $72.0 \%$ & $12.0 \%$ & $8.4 \%$ \\
\hline
\end{tabular}


The first five columns of table 5.1 contain data from table 4.1. The first three columns are New Zealand data. Poverty reduction refers to the proportion of market income poor that are brought above the poverty threshold by government intervention. Throughout this chapter italic fonts are used to denote counterfactual analyses. The counterfactual analysis in table 5.1 is found in column six and seven, and shows what the poverty rates would have been in New Zealand if government intervention had brought the same proportion of poor out of poverty as was done in Norway and Sweden respectively. It should, in other words, be compared to column two. The analysis shows that the household poverty rate would have been 7 per cent lower with Norwegian policy and 41 per cent lower with Swedish policy. This difference which seems dramatically large at first glimpse reflects that the poverty reduction rate in Norway was $48.5 \%$, only slightly higher than New Zealand's at 45.0\%, while Sweden's was markedly higher at 67.3\%. For child poverty the equivalent figures was 51 per cent and 65 per cent. These findings suggest that higher benefit levels, child assistance and more progressive taxes could have lowered child poverty and overall poverty substantially in New Zealand in year 2000.

Table 5.2 Scandinavian household and child poverty rates with New Zealand market poverty rates

\begin{tabular}{|l|l|l|l|l|l|}
\hline & $\begin{array}{l}\text { Actual } \\
\text { market } \\
\text { income } \\
\text { poverty } \\
\text { rate }\end{array}$ & $\begin{array}{l}\text { Dispos- } \\
\text { able } \\
\text { poverty } \\
\text { rate }\end{array}$ & $\begin{array}{l}\text { Net } \\
\text { reduction } \\
\text { by taxes } \\
\text { and } \\
\text { transfers }\end{array}$ & $\begin{array}{l}\text { New } \\
\text { Zealand } \\
\text { market } \\
\text { income } \\
\text { poverty }\end{array}$ & $\begin{array}{l}\text { Disposable } \\
\text { poverty rate } \\
\text { with New } \\
\text { Zealand's } \\
\text { market } \\
\text { poverty }\end{array}$ \\
\hline Norwegian households & $36.1 \%$ & $18.6 \%$ & $48.5 \%$ & $32.7 \%$ & $16.8 \%$ \\
\hline Norwegian children & $16.4 \%$ & $6.6 \%$ & $59.8 \%$ & $29.9 \%$ & $12.0 \%$ \\
\hline Swedish households & $39.8 \%$ & $13.0 \%$ & $67.3 \%$ & $32.7 \%$ & $10.7 \%$ \\
\hline Swedish children & $20.0 \%$ & $5.6 \%$ & $72.0 \%$ & $29.9 \%$ & $8.4 \%$ \\
\hline
\end{tabular}

The next step is to analyse to what extent differences in market poverty, which is less directly linked to governments' policy and policy reforms than disposable income poverty, explains why disposable income poverty is lower in Scandinavia than in New Zealand. This is done by calculating what the disposable income poverty rate would have been if the poverty reduction rates were constant, but the market poverty rates were changed to rate observed in New Zealand. In table 5.2 the first 
three columns contain Norwegian and Swedish data from table 4.1. Column four contain the New Zealand equivalent to the data in column three, which is why data in row one and three, and two and four are identical. These data are also from table 4.1. The fifth column contains the counterfactual analysis, and shows what the disposable income poverty rate would have been, if the market income were not the figure found in column one, but rather the figure from New Zealand in column four. Reflecting that household market income poverty rates were higher in Scandinavia, the observed disposable income poverty rates are 10 per cent higher than what it would have been with New Zealand's market income poverty rates in Norway. The equivalent for Sweden was 22 per cent higher. Market income child poverty rates were higher in New Zealand, and having New Zealand's market child poverty rate would have increased the disposable child poverty rate by 82 per cent in Norway and 50 per cent in Sweden. 


\subsection{Household and child poverty level analysis - ethnicity}

It was pointed out in section 3.2 that in a small-N study (in the sense of using data from a small number of countries) like this it is possible to include a variable like ethnicity, which it is too complicated to include in large-N studies. That is, however, not to say that making data on ethnicity and poverty comparable across the three countries in question is straightforward. This section will give particular attention to ethnic minority groups that has higher poverty rates than the average population. As was illustrated by the Norwegian case, looking at aggregate figures only in this area is not unproblematic, but for New Zealand that appears to be the best data available. In New Zealand these groups are households where the head identifies with Māori or Pacific Island identities, and children living in households where the head identifies as Māori, Pacific Islander or 'other' (i.e. not European New Zealander). These are grouped together to form one entity so to make it comparable to the single entity of immigrants in Norway and Sweden. It would be easy to argue that these groups are so heterogeneous that comparing them are not meaningful. However, the data show that at least in some of the cases these groups' aggregated poverty levels differs from the average of the total population in the country they live in. It is on that basis the analysis in this chapter is done, it is by no means argued here that these are good measures of the impact of ethnic affiliation on poverty.

This section starts with table 5.3 which, based on tables 4.2, estimates what the disposable income poverty rates would have been in New Zealand if the poverty reduction rate among the ethnic groups with higher poverty than the average were equal to that of the immigrant population in Norway and Sweden. In Norway, the poverty reduction rate were lower for immigrants than the overall population (whereas minority groups in New Zealand had higher rates of poverty reduction than the average, but recall that the overall market income poverty among Norwegian immigrants were indistinguishable to that of the average), at 28.9 per cent for households and 46.4 per cent for children. In column 5 it is calculated what the disposable income would have been if these poverty reduction rates were applied to the poverty exposed ethnic minorities. The Swedish immigrant population poverty reduction rates were only slightly lower than those for the overall population, at 62.8 per cent for households and 69.7 per cent for children, and the disposable income for 
the poverty exposed ethnic groups with these poverty reduction rates are calculated in column 6.

Table 5.3 Counterfactual analysis of New Zealand child and household poverty by ethnicity

\begin{tabular}{|c|c|c|c|c|c|c|}
\hline 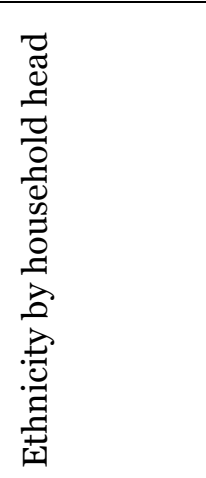 & 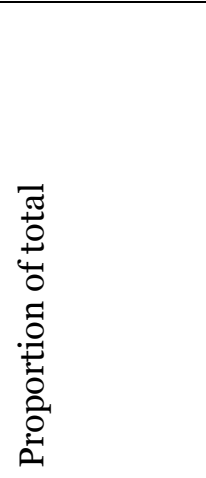 & 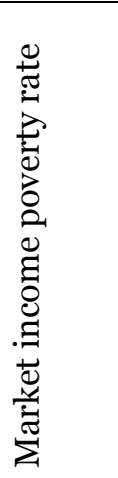 & 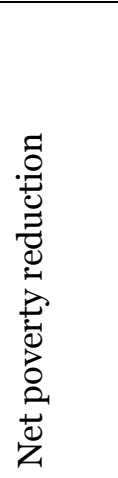 & 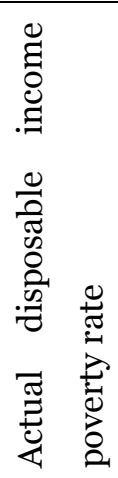 & 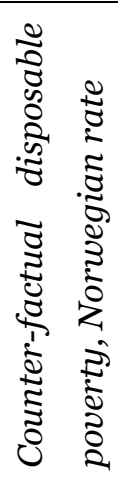 & 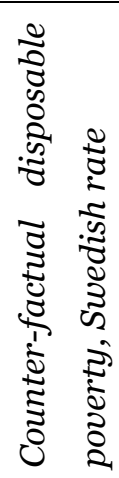 \\
\hline $\begin{array}{l}\text { European } \\
\text { household }\end{array}$ & $80.1 \%$ & $31.0 \%$ & $48.4 \%$ & $16.0 \%$ & $N / A$ & $N / A$ \\
\hline $\begin{array}{l}\text { Māori } \\
\text { Household }\end{array}$ & $11.2 \%$ & $44.1 \%$ & $37.9 \%$ & $27.4 \%$ & $31.4 \%$ & $16.4 \%$ \\
\hline $\begin{array}{l}\text { Pacific } \\
\text { households }\end{array}$ & $3.5 \%$ & $45.4 \%$ & $31.1 \%$ & $31.3 \%$ & $32.3 \div$ & $16.9 \%$ \\
\hline Other, HH & $5.2 \%$ & $27.1 \%$ & $26.0 \%$ & $20.1 \%$ & $N / A$ & $N / A$ \\
\hline Total, HH & $1,374,000$ & $32.7 \%$ & $45.0 \%$ & $18.0 \%$ & $18.5 \%$ & $16.3 \%$ \\
\hline $\begin{array}{l}\text { European } \\
\text { children }\end{array}$ & $68.3 \%$ & $22.8 \%$ & $8.3 \%$ & $20.9 \%$ & $N / A$ & $N / A$ \\
\hline $\begin{array}{l}\text { Māori } \\
\text { Children }\end{array}$ & $16.6 \%$ & $47.2 \%$ & $29.7 \%$ & $33.2 \%$ & $33.6 \%$ & $14.3 \%$ \\
\hline $\begin{array}{l}\text { Pacific } \\
\text { children }\end{array}$ & $7.6 \%$ & $51.7 \%$ & $33.8 \%$ & $34.2 \%$ & $36.8 \%$ & $15.7 \%$ \\
\hline $\begin{array}{l}\text { Other, } \\
\text { children }\end{array}$ & $7.4 \%$ & $34.4 \%$ & $26.5 \%$ & $25.3 \%$ & $24.5 \%$ & $10.4 \%$ \\
\hline $\begin{array}{l}\text { Total, } \\
\text { children }\end{array}$ & 886,000 & $29.9 \%$ & $18.7 \%$ & $24.3 \%$ & $24.4 \%$ & $18.6 \%$ \\
\hline
\end{tabular}

The total rate for child and household poverty in the counterfactual columns shows what the weighted poverty rate would have been if the Swedish and Norwegian reduction rate had been applied to the poverty exposed ethnic groups only, and the less exposed groups had been left unchanged. These findings show that the total poverty would have increased slightly in the Norwegian model, and reduced 
significantly in the Swedish case, but in both cases the impact would naturally be miniscule compared to the impact done by the models run in table 5.1.

In a similar vein one could ask how Norwegian and Swedish would be affected by having an ethnic composition or market poverty rate similar to that of New Zealand. In New Zealand, the sum of Māori and Pacific households extended to 14.7 per cent of the total number of households. If the proportion of immigrant households in Norway were increased from 9.6 per cent to 14.7 per cent, the total disposable income poverty rate would, according to table 4.2, ceteris paribus have been increased from 18.6 per cent to 19.0 per cent, in other words a marginal change. In this calculation the poverty rate of immigrants and non-immigrants in Norway are kept constant, only the proportion of immigrants is changed. The proportion of Swedish immigrant household was 14.1 per cent, so obviously introducing the proportion of ethnicities particularly vulnerable to poverty that New Zealand had (14.7 per cent) would have led to changes too small to be measure in any meaningful way. The sum of children living in New Zealand households where the head is of Māori, Pacific Island or 'other' ethnicity (the ethnicities that has higher than average child poverty), extended to 31.6 per cent of the total, which compared to 11.8 per cent of children in households with immigrant head or spouse in Norway and 20.7 per cent in Sweden. If the proportion of immigrant children were increased to 31.6 per cent, that would have increased the child poverty in Norway from 6.6 per cent to 8.6 per cent and from 5.6 per cent to 6.3 per cent in Sweden, all according to calculations based on tables 4.2. That child poverty is more affected than household poverty is the combined result of two factors: that the higher poverty rate among immigrants in Scandinavia was more pronounced for children than households, and that the increase in proportion in New Zealand of the total was larger for children than household.

While that would have been an increase of Norwegian child poverty of over a quarter, an equally important driver behind the ethnic differences in child and household poverty in New Zealand were the differences in market income. The weighted average market income poverty rate among Māori and Pacific Island headed households were 44.4 per cent, and children in these and households with head of 'other' ethnicity had a market income poverty rate of 45.3 per cent, or rates that were 35.8 per cent and 51.5 per cent higher than the respective averages. If Norwegian and Swedish immigrant households had market income poverty rates 
that much higher than the average (and the proportion of immigrant households and their poverty reduction rates were held constant) they would have had disposable income poverty rate of 34.9 per cent and 20.1 per cent, respectively, compared to the actual figures of 25.6 per cent and 16.2 per cent. For the total household poverty rate that would equate an increase from 18.6 per cent to 19.5 per cent in Norway and from 13.0 per cent to 13.5 per cent in Sweden. The equivalent immigrant child poverty rates would have shown an equivalent increase from 15.5 per cent to 23.5 per cent in Norway and 10.8 per cent to 16.3 per cent in Sweden. That would extend to an increase of the total child poverty from 6.6 per cent to 7.5 per cent in Norway and from 5.6 per cent to 6.7 per cent in Sweden. 


\subsection{Household and child poverty level analysis - demographics: age and family structure}

This section will, like the previous one perform a counterfactual analysis of the impact on disposable income poverty rates if New Zealand had the poverty reduction rate of Norway and Sweden, and the impact on Swedish and Norwegian poverty rates of having composition and market poverty rates equal to that of New Zealand, but rather than dealing with ethnicity, this section will look at the family structure and age variables from sections 3.3 and 4.6.

Table 5.4 A Counterfactual analysis of New Zealand household poverty rates by number of children, based on Scandinavian poverty reduction rates

\begin{tabular}{|c|c|c|c|c|c|c|}
\hline & 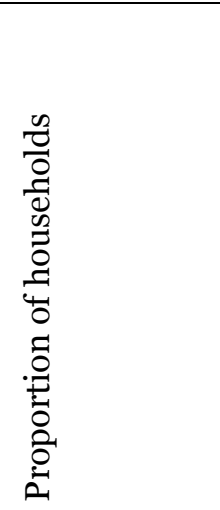 & 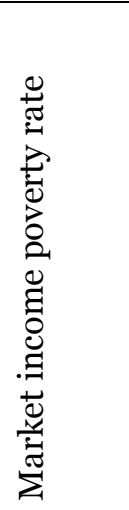 & 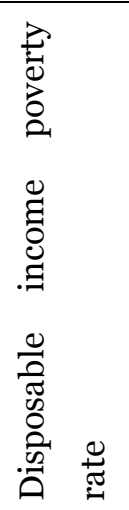 & 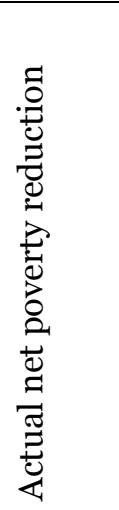 & 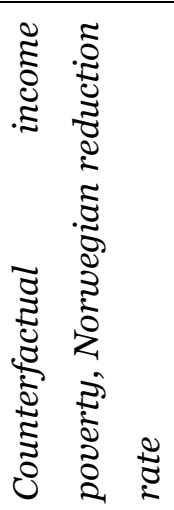 & 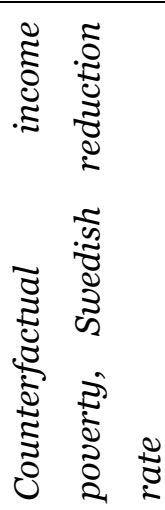 \\
\hline $\begin{array}{l}\text { No } \\
\text { children }\end{array}$ & $66.1 \%$ & $35.3 \%$ & $16.1 \%$ & $54.4 \%$ & $18.8 \%$ & $11.6 \%$ \\
\hline One child & $13.2 \%$ & $27.4 \%$ & $17.5 \%$ & $36.3 \%$ & $10.7 \%$ & $9.0 \%$ \\
\hline $\begin{array}{l}\text { Two } \\
\text { children }\end{array}$ & $13.5 \%$ & $24.9 \%$ & $22.4 \%$ & $10.0 \%$ & $10.8 \%$ & $7.5 \%$ \\
\hline $\begin{array}{l}\text { Three } \\
\text { children }\end{array}$ & $5.2 \%$ & $26.2 \%$ & $22.5 \%$ & $14.0 \%$ & $11.6 \%$ & $7.4 \%$ \\
\hline $\begin{array}{l}\text { Four } \\
\text { children }\end{array}$ & $1.4 \%$ & $45.1 \%$ & $39.6 \%$ & $12.2 \%$ & $15.6 \%$ & $8.9 \%$ \\
\hline $\begin{array}{l}\text { Five or } \\
\text { more } \\
\text { children }\end{array}$ & $0.6 \%$ & $75.8 \%$ & $52.2 \%$ & $31.2 \%$ & $9.4 \%$ & $12.4 \%$ \\
\hline $\begin{array}{l}\text { Total or } \\
\text { average }\end{array}$ & $1,374,152$ & $32.7 \%$ & $18.0 \%$ & $45.0 \%$ & $16.2 \%$ & $10.5 \%$ \\
\hline
\end{tabular}

The first four columns of table 5.4 is from table $4.3 \mathrm{~A}$, the last two is calculated based on the Norwegian and Swedish poverty reduction rate from 
government intervention, and the New Zealand market income poverty rate, and shows what the disposable poverty rate would be in New Zealand households if the poverty reduction rate were equal to that in Norway and Sweden, respectively. The values in the two cells of the counterfactual columns and average row are weighted averages, and are thus slightly different from the values in table 5.1, but the factor is clearly not large enough to make a large difference.

If Norway had the composition of households according to number of children that New Zealand has, its household disposable income poverty rate would ceteris paribus be 17.7 per cent rather than 18.0 per cent, for Sweden it would be 12.1 per cent rather than 13.0 per cent. This is calculated by finding the sum of the products of New Zealand's proportion of households in the categories of number of children and the disposable income poverty rate for the same categories in Norway and Sweden.

Table 5.4 B Counterfactual analysis of Scandinavian household poverty rates by number of children, based on New Zealand market poverty rate

\begin{tabular}{|c|c|c|c|c|}
\hline & 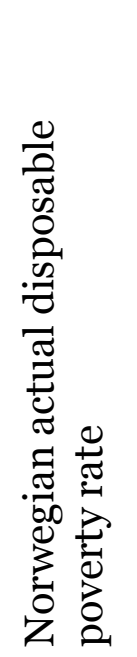 & 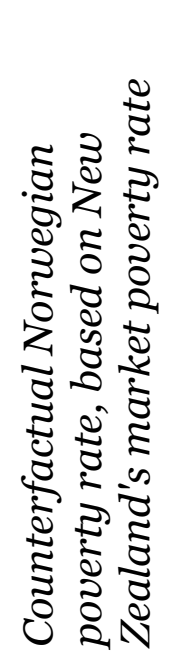 & 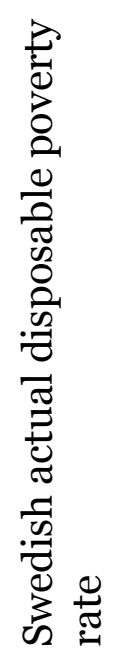 & 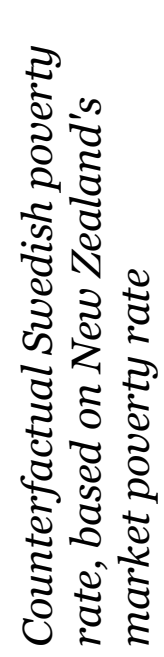 \\
\hline $\begin{array}{l}\text { No } \\
\text { children }\end{array}$ & $23.2 \%$ & $28.2 \%$ & $15.4 \%$ & $30.2 \%$ \\
\hline One child & $7.8 \%$ & $14.4 \%$ & $6.6 \%$ & $14.5 \%$ \\
\hline $\begin{array}{l}\text { Two } \\
\text { children }\end{array}$ & $6.4 \%$ & $11.0 \%$ & $5.1 \%$ & $12.8 \%$ \\
\hline $\begin{array}{l}\text { Three } \\
\text { children }\end{array}$ & $5.6 \%$ & $9.3 \div$ & $5.1 \%$ & $13.3 \%$ \\
\hline $\begin{array}{l}\text { Four } \\
\text { children }\end{array}$ & $8.8 \%$ & $14.0 \%$ & $5.6 \%$ & $15.6 \%$ \\
\hline $\begin{array}{ll}\text { Five } & \text { or } \\
\text { more } \\
\text { children }\end{array}$ & $4.4 \%$ & $8.6 \%$ & $10.8 \%$ & $16.1 \%$ \\
\hline $\begin{array}{l}\text { Total or } \\
\text { average }\end{array}$ & $18.6 \%$ & $23.8 \%$ & $13.0 \%$ & $26.1 \%$ \\
\hline
\end{tabular}


Table 5.4 B shows the actual disposable income poverty rates for Norwegian and Swedish households from tables 4.3 in columns one and three, while columns two and four contains calculations of what that poverty rate would have been had the country had New Zealand's market poverty rates, but the poverty reduction rates were kept constant. Again, the total is weighted, and thus different from that in table 5.2. The substantially higher values in both totals (more than double the rate in Sweden) compared to table 5.2 is interesting because it shows that not only the higher overall redistribution rate in Sweden causes Sweden to have lower poverty than New Zealand, but also the way it is calibrated towards the households where the market income poverty is the greatest. The same applies to Norway, but to a slightly lesser extent. Again, this must be qualified with the factor mentioned in sections 3.3 and 4.6, namely that not all public old-age pension income are defined as transfers in Scandinavia, but it is in New Zealand.

Table 5.5A does the same estimations as table 5.4A, but with family types rather than number of children in the rows, and thus based on data from table $4.4 \mathrm{~A}$ and $4.5 \mathrm{~A}$ rather than $4.3 \mathrm{~A}$. The four counterfactual columns are thus estimates of child and household poverty rates where the market poverty rate in New Zealand is multiplied by the rate at which government intervention (the net effect of transfers and taxes) reduced poverty in Norway and Sweden. 
Table 5.5 A Counterfactual analysis of New Zealand household poverty rates by family type, based on Scandinavian poverty reduction rates

\begin{tabular}{|c|c|c|c|c|c|c|c|c|}
\hline & 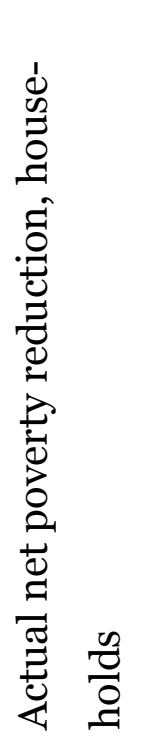 & 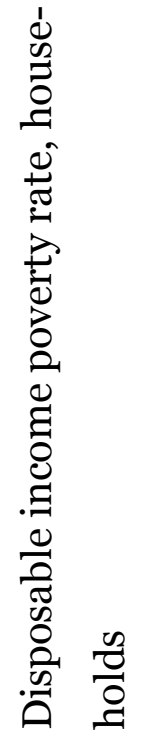 & 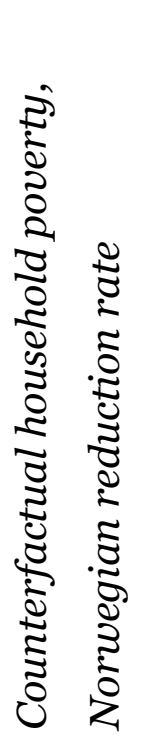 & 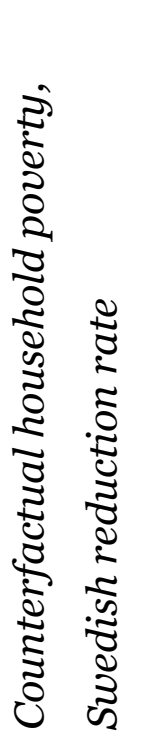 & 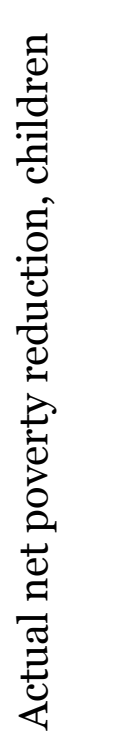 & 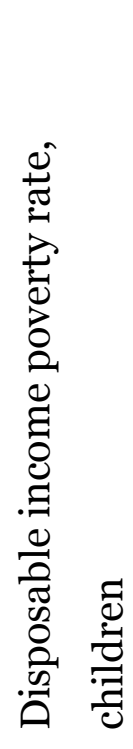 & 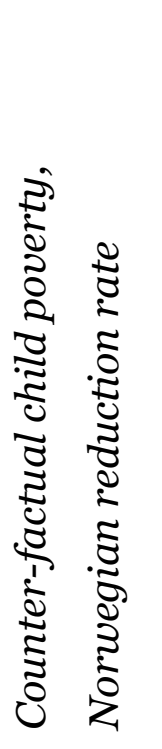 & 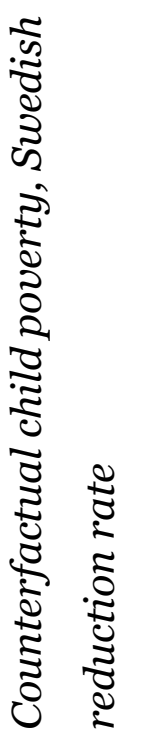 \\
\hline 1 adult & $50.6 \%$ & $26.8 \%$ & $36.2 \%$ & $22.2 \frac{\circ}{0}$ & - & - & - & - \\
\hline $\begin{array}{l}1 \text { adult, } 1 \text { or } \\
\text { more child }\end{array}$ & $17.5 \%$ & $64.7 \%$ & $30.0 \div$ & $22.9 \%$ & $14.4 \%$ & $71.6 \%$ & $31.6 \%$ & $23.3 \%$ \\
\hline 2 adults & $59.6 \%$ & $12.4 \%$ & $6.0 \%$ & $3.3 \%$ & - & - & $\begin{array}{lll}- & \\
- & \end{array}$ & - \\
\hline $\begin{array}{l}2 \text { adults, } 1 \\
\text { child }\end{array}$ & $41.9 \%$ & $11.1 \%$ & $8.8 \%$ & $6.5 \%$ & $41.9 \%$ & $11.1 \%$ & $8.8 \%$ & $6.5 \%$ \\
\hline $\begin{array}{l}2 \text { adults, } 2 \\
\text { children }\end{array}$ & $2.4 \%$ & $16.1 \%$ & $8.5 \frac{\circ}{\circ}$ & $5.9 \%$ & $2.1 \%$ & $16.1 \%$ & $8.5 \%$ & $5.9 \%$ \\
\hline $\begin{array}{l}2 \text { adults, } 3 \\
\text { or more } \\
\text { children }\end{array}$ & $9.8 \%$ & $19.3 \%$ & $9.3 \%$ & $5.1 \%$ & $10.8 \%$ & $20.7 \%$ & $9.4 \%$ & $5.0 \%$ \\
\hline $\begin{array}{l}3 \text { or more } \\
\text { adults }\end{array}$ & $53.2 \%$ & $5.2 \%$ & $1.4 \%$ & $2.4 \%$ & - & - & - & - \\
\hline $\begin{array}{l}3 \text { or more } \\
\text { adults } \\
1 \text { or more } \\
\text { children }\end{array}$ & $43.9 \%$ & $11.1 \%$ & $5.0 \div$ & $4.6 \%$ & $43.9 \%$ & $14.4 \%$ & $6.0 \%$ & $5.1 \%$ \\
\hline $\begin{array}{l}\text { Total in } \\
\text { thousands } \\
\text { or average }\end{array}$ & $45.0 \%$ & $18.0 \%$ & $14.2 \%$ & $9.3 \%$ & $18.7 \%$ & $24.3 \%$ & $11.5 \%$ & $8.0 \%$ \\
\hline
\end{tabular}

Table 5.5 A confirms that the Scandinavian policies are more successful at reducing child poverty, even marginally more so when taking into account what family types child poverty is reduced in. This highlights that differences in policy is in many ways more important than differences in composition of households and 
distribution of market poverty into different family types when explaining the higher disposable income poverty in New Zealand. As was already pointed out in section 4.6, especially children living in households with one adult would be less likely to live in poverty. The only household type that would be worse off with a Norwegian poverty reduction rate was single adult households. The Swedish poverty reduction was higher for all household types.

If Norway had New Zealand's composition of family types, ceteris paribus its child poverty rate would be $6.2 \%$ rather than $6.6 \%$. The equivalent figure for Sweden was $4.8 \%$ rather than $5.6 \%$. One interpretation of these finding is that the policies in Scandinavia was geared towards the composition of family types found in New Zealand. Certainly it means that composition of family types cannot explain the higher child poverty rate in New Zealand, if anything this particular finding suggests that it should be lower. Granted, 90\% of the decrease in Swedish child poverty stemmed from the lower proportion of children living with only one adult. The equivalent figures for households and household poverty rate confirms that the compositions of family type are not an advantage for the Scandinavian countries; if Norway had New Zealand's family composition, the country's disposable income household poverty rate would fall from $18.6 \%$ to $12.7 \%$, and Sweden's would fall from 13.0\% to 8.4\%. Again, this shows such dramatic differences that the different types of old age pension probably cannot explain all of them. Much of the difference can be explained by the higher proportion of poor, single adults in Scandinavia. 
Table 5.5 B Counterfactual analysis of Scandinavian household poverty rates by family types, based on New Zealand market poverty rate

\begin{tabular}{|c|c|c|c|c|c|c|c|c|}
\hline & 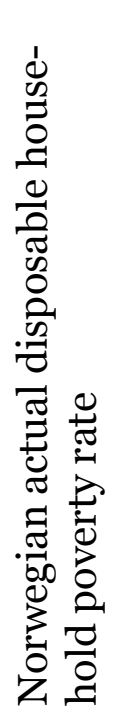 & 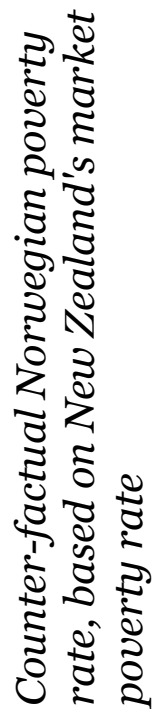 & 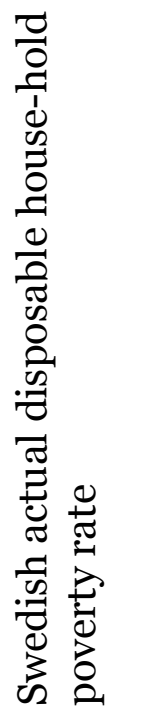 & 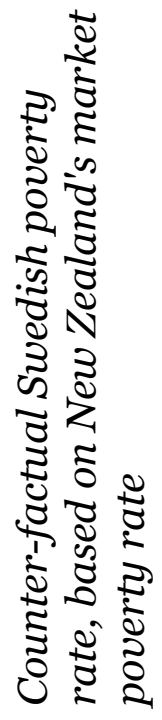 & 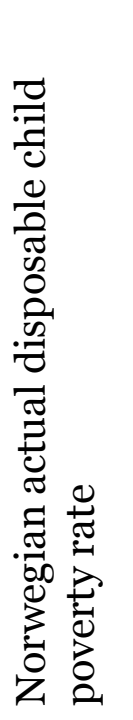 & 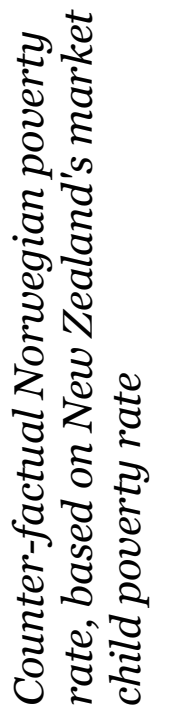 & 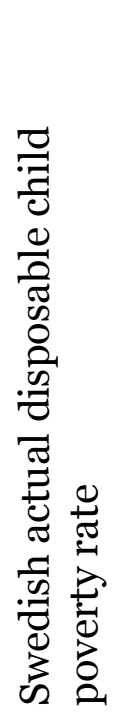 & 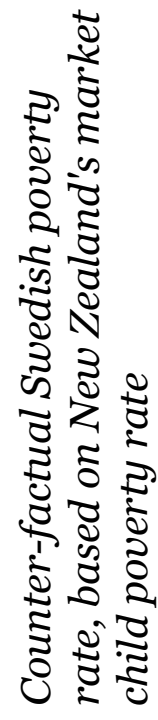 \\
\hline 1 adult & $36.3 \%$ & $36.2 \frac{\circ}{0}$ & $22.7 \%$ & $22.2 \frac{\circ}{0}$ & - & - & - & - \\
\hline $\begin{array}{l}1 \text { adult, } 1 \text { or } \\
\text { more child }\end{array}$ & $21.4 \%$ & $30.0 \%$ & $14.4 \%$ & $22.9 \%$ & $22.2 \%$ & $31.6 \div$ & $14.3 \%$ & $23.3 \div$ \\
\hline 2 adults & $6.6 \%$ & $6.0 \%$ & $3.9 \%$ & $3.3 \%$ & - & - & - & - \\
\hline $\begin{array}{l}2 \text { adults, } 1 \\
\text { child }\end{array}$ & $3.5 \%$ & $8.8 \%$ & $3.7 \%$ & $6.5 \%$ & $3.5 \%$ & $8.8 \%$ & $3.7 \%$ & $6.5 \%$ \\
\hline $\begin{array}{l}2 \text { adults, } 2 \\
\text { children }\end{array}$ & $3.7 \%$ & $8.5 \%$ & $3.7 \%$ & $5.9 \%$ & $3.7 \%$ & $8.5 \frac{\circ}{0}$ & $3.7 \%$ & $5.9 \%$ \\
\hline $\begin{array}{l}2 \text { adults, } 3 \\
\text { or more } \\
\text { children }\end{array}$ & $4.7 \%$ & $9.3 \%$ & $3.7 \%$ & $5.1 \%$ & $4.9 \%$ & $9.4 \%$ & $3.8 \%$ & $5.0 \%$ \\
\hline $\begin{array}{l}3 \text { or more } \\
\text { adults }\end{array}$ & $1.1 \%$ & $1.4 \%$ & $1.7 \%$ & $2.4 \%$ & - & - & - & - \\
\hline $\begin{array}{l}3 \text { or more } \\
\text { adults } \\
1 \text { or more } \\
\text { children }\end{array}$ & $1.6 \%$ & $5.0 \%$ & $1.8 \%$ & $4.6 \%$ & $1.7 \%$ & $6.0 \div$ & $1.9 \%$ & $5.1 \%$ \\
\hline $\begin{array}{l}\text { Weighted } \\
\text { average }\end{array}$ & $18.6 \%$ & $20.0 \%$ & $13.0 \%$ & $13.6 \%$ & $6.6 \%$ & $12.1 \%$ & $5.6 \%$ & $9.0 \%$ \\
\hline
\end{tabular}

Table 5.5 B shows that while Scandinavia would have coped well with a composition of family types closer to that of New Zealand, having New Zealand's market poverty rate would have led to substantial increase in disposable income 
poverty, in particular when weighted by children. Despite these two factors, the child poverty rate in Norway would still be less than half of that observed in New Zealand.

Table 5.6 A Counterfactual analysis of New Zealand household poverty rates by age of household head, based on Scandinavian poverty reduction rates

\begin{tabular}{|c|c|c|c|c|c|c|c|c|}
\hline 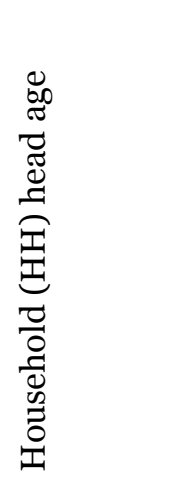 & 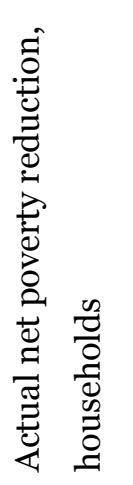 & 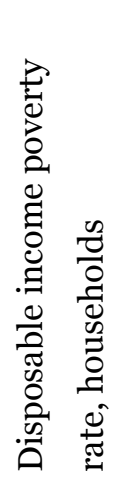 & 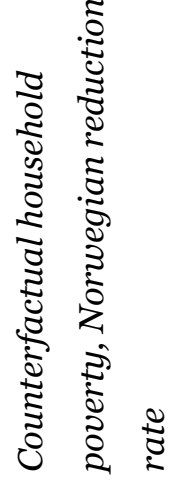 & 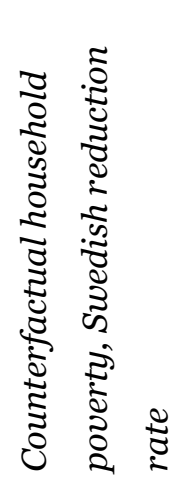 & 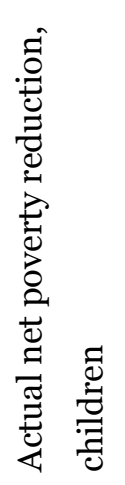 & 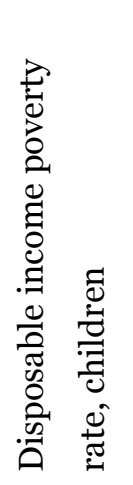 & 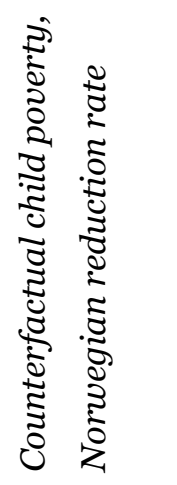 & 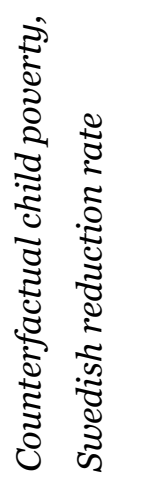 \\
\hline $15-24$ & $18.3 \%$ & $28.2 \%$ & $33.1 \%$ & $33.3 \%$ & $16.9 \%$ & $45.8 \%$ & $16.3 \%$ & $40.9 \%$ \\
\hline $25-29$ & $21.6 \%$ & $21.1 \%$ & $20.5 \%$ & $20.3 \%$ & $26.9 \%$ & $35.6 \%$ & $20.6 \div$ & $17.1 \%$ \\
\hline $30-39$ & $12.6 \%$ & $16.0 \%$ & $9.8 \%$ & $6.4 \div$ & $9.6 \%$ & $25.5 \%$ & $11.3 \%$ & $7.4 \%$ \\
\hline $40-49$ & $18.5 \%$ & $13.2 \%$ & $7.9 \%$ & $5.1 \%$ & $21.3 \%$ & $17.7 \%$ & $10.3 \div$ & $5.5 \%$ \\
\hline $50-59$ & $23.0 \%$ & $15.4 \%$ & $8.4 \%$ & $4.8 \%$ & $20.5 \%$ & $20.5 \%$ & $8.5 \div$ & $4.4 \%$ \\
\hline $60-64$ & $53.9 \%$ & $18.2 \%$ & $17.2 \%$ & $6.2 \%$ & * & 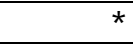 & $47.0 \div$ & $25.8 \%$ \\
\hline $65^{+}$ & $69.4 \%$ & $23.6 \%$ & $31.9 \div$ & $14.9 \%$ & * & * & * & $18.0 \%$ \\
\hline $\begin{array}{l}\text { Weighted } \\
\text { average }\end{array}$ & $45.0 \%$ & $18.0 \%$ & $16.1 \%$ & $10.1 \%$ & $18.7 \%$ & $24.3 \%$ & $11.4 \%$ & $12.2 \%$ \\
\hline
\end{tabular}

(*=Insufficient data)

The columns in table 5.6A are the same as those used in table $5.5 \mathrm{~A}$; the

difference is obviously that in the rows family type has been replaced by the household head's age.

The household poverty rates shows how the Scandinavian poverty reduction rate would reduce poverty rates among middle age households, i.e. those within working age, but would increase the poverty rate among the oldest and the youngest. Comparing the counterfactual total poverty rates here and in table 5.1 gives a rough estimate of the net effect of the two factors. For households table 5.1, which estimates the effect of New Zealand having Scandinavia's poverty reduction rate without taking differences across age groups into account, the household poverty rates would have been 16.8 per cent with Norwegian poverty reduction and 10.7 with Sweden's poverty reduction. Scandinavian poverty reduction rates are in other words more effective in reducing poverty when applied to specific age groups.

When looking at child poverty it is necessary to keep the skewed distribution in mind: the vast majority of children live in households where the head 
is between 30 and 50 years old, especially in Scandinavia. For the older age groups the number of children is in fact so low that it is difficult to estimate the poverty rate in New Zealand and Norway. For all age groups where reliable data were available for all countries Scandinavian poverty reduction rate is lower than the one for New Zealand. When comparing the total child poverty in table 5.1 and the equivalent rate in table $5.6 \mathrm{~A}$ it is clear that taking household head age into account (as is done in table $5.6 \mathrm{~A}$, but not 5.1) when implementing the reduction rate the total child poverty rate is slightly lower when the Norwegian rate is applied, but substantially higher when the Swedish rate is applied. In other words, no firm pattern appears when taking the age of household head into account when implementing Scandinavian poverty reduction rates on New Zealand's rate of child poverty. 


\begin{tabular}{|c|c|c|c|c|c|c|c|c|}
\hline 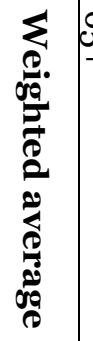 & 里 & 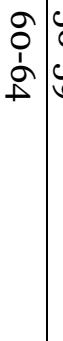 & & & & & & House-hold (HH) head age \\
\hline 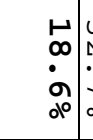 & $\begin{array}{l}\omega \\
N \\
\vdots \\
10 \\
10\end{array}$ & \begin{tabular}{|c|}
$\dot{\omega}$ \\
$\omega$ \\
$\dot{\alpha}$ \\
$010^{\circ}$
\end{tabular} & \begin{tabular}{l|l}
9 \\
0 \\
010 \\
010
\end{tabular} & $\begin{array}{l}9 \\
\text { in } \\
010\end{array}$ & $\begin{array}{l}6 \\
\\
0 \\
010\end{array}$ & $\begin{array}{l}N \\
\stackrel{N}{0} \\
\dot{\omega} \\
00^{\circ}\end{array}$ & $\begin{array}{l}0 \\
\dot{y} \\
\\
010\end{array}$ & $\begin{array}{l}\text { Norwegian actual disposable house-hold poverty } \\
\text { rate }\end{array}$ \\
\hline$\underset{c}{n}$ & $\begin{array}{c}\omega \\
\omega \\
0 \\
0 \\
010\end{array}$ & $\begin{array}{l}\omega \\
\dot{N} \\
\dot{N} \\
010\end{array}$ & $\begin{array}{l}\infty \\
\dot{1} \\
010 \\
10\end{array}$ & $\begin{array}{l}v \\
\dot{0} \\
010\end{array}$ & \begin{tabular}{l|l|l|l|l}
6 \\
$\infty$ \\
010 \\
010
\end{tabular} & $\begin{array}{l}N \\
0 \\
i \\
\text { olo }\end{array}$ & $\begin{array}{l}\omega \\
\omega \\
\dot{\omega} \\
010\end{array}$ & $\begin{array}{l}\text { Counter-factual Norwegian poverty rate, based on } \\
\text { New Zealand's market poverty rate }\end{array}$ \\
\hline 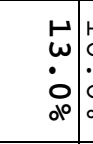 & & \begin{tabular}{|c|c|c|} 
& \\
$\dot{1}$ \\
olo \\
\end{tabular} & 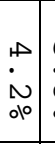 & $\begin{array}{l}G \\
\infty \\
0 \\
10\end{array}$ & $\begin{array}{c}. \\
i \\
0.0\end{array}$ & 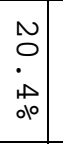 & $\begin{array}{c}\mathcal{M} \\
\omega \\
\omega \\
010^{\circ}\end{array}$ & Swedish actual disposable household poverty rate \\
\hline 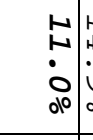 & $\begin{array}{l}1 \\
1 \\
6 \\
0 \\
010\end{array}$ & \begin{tabular}{|c|}
9 \\
$\grave{N}$ \\
010
\end{tabular} & $\begin{array}{c}\infty \\
\dot{\infty} \\
\infty \\
010\end{array}$ & $\begin{array}{l}G \\
\dot{\sim} \\
010\end{array}$ & $\begin{array}{l}\substack{9 \\
\text { i } \\
010} \\
\end{array}$ & $\begin{array}{l}N \\
0 \\
\dot{\omega} \\
010\end{array}$ & $\begin{array}{c}\omega \\
\omega \\
\omega \\
010\end{array}$ & $\begin{array}{l}\text { Counter-factual Swedish poverty rate, based on } \\
\text { New Zealand's market poverty rate }\end{array}$ \\
\hline 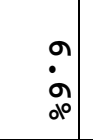 & $*$ & $\begin{array}{l}-4 \\
6 \\
010^{\circ}\end{array}$ & $\begin{array}{c}\omega \\
\infty \\
\infty \\
010\end{array}$ & $\begin{array}{l}+ \\
: \\
\\
10\end{array}$ & $\stackrel{\sim}{\sim}$ & $\begin{array}{c}\dot{b} \\
\dot{\omega} \\
\dot{0} 0^{\circ}\end{array}$ & $\begin{array}{l}\stackrel{\omega}{\infty} \\
\dot{\omega} \\
0^{\circ}\end{array}$ & Norwegian actual disposable child poverty rate \\
\hline 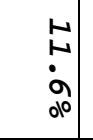 & $*$ & $\begin{array}{l}\Delta \\
\stackrel{1}{1} \\
0 \\
010\end{array}$ & $\begin{array}{ll}\infty \\
ن \\
01 \\
010\end{array}$ & $\begin{array}{l}\vec{w} \\
\dot{\omega} \\
\dot{\omega} \\
010\end{array}$ & $\begin{array}{l}\vec{\sim} \\
\vec{\sim} \\
\dot{\omega} \\
010\end{array}$ & $\begin{array}{l}N \\
0 \\
\dot{2} \\
\text { olo }\end{array}$ & $\begin{array}{l}w \\
a \\
\dot{\omega} \\
010\end{array}$ & $\begin{array}{l}\text { Counter-factual Norwegian child poverty rate, } \\
\text { based on New Zealand's market child poverty rate }\end{array}$ \\
\hline 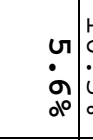 & $\mid \begin{array}{c}+ \\
0 \\
w \\
010\end{array}$ & \begin{tabular}{|l|l|l} 
\\
$\vdots$ \\
$u$ \\
$010^{\circ}$
\end{tabular} & $\begin{array}{c}N \\
\sim \\
010\end{array}$ & $\begin{array}{c}\omega \\
\vdots \\
10 \\
10\end{array}$ & 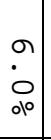 & $\begin{array}{l}\dot{\omega} \\
\tilde{L} \\
\dot{0} \\
0.0\end{array}$ & 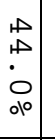 & Swedish actual disposable child poverty rate \\
\hline$i_{0}$ & $\begin{array}{c}1 \\
\infty \\
0 \\
0 \\
010\end{array}$ & \begin{tabular}{|l|}
$N$ \\
$\sim$ \\
$\infty$ \\
010 \\
010
\end{tabular} & & & 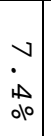 & $\begin{array}{l}\stackrel{w}{v} \\
\dot{L} \\
\text { olo }\end{array}$ & $\begin{array}{l}\Delta \\
\stackrel{\Delta}{0} \\
\dot{0} \\
010\end{array}$ & $\begin{array}{l}\text { Counter-factual Swedish child poverty rate, based } \\
\text { on New Zealand's market child poverty rate }\end{array}$ \\
\hline
\end{tabular}




\subsection{Household and child poverty level analysis - income source}

This section attempts to give an accessible overview of the data in section 4.8. As in previous sections it will demonstrate what would happen if New Zealand had Scandinavian poverty reduction rates or if Scandinavia had New Zealand's market poverty or demographic composition. In this section the focus is - as section 4.8 - on income source.

The New Zealand data categories differ slightly from those used in Norway and Sweden; the Scandinavian poverty data separates household head and head's spouse into those with main income from benefits and employment. This means that in this section households are separated into three groups: those where one adult (head or spouse) has employment as main income, those where two or more (head and spouse) has employment as main income and the remaining households where some form of benefit are presumed to be the main source of income. As seen in section 4.8 the New Zealand data provide some more information, with slightly different categories; households are separated into five groups: those with benefits as their main income, those with parts of their income from benefits, and those with no benefit income divided into households with 1, 2, or three or more adults. In order to make the five categories used in New Zealand comparable with the three used in Scandinavia as possible, two of the pairs of the New Zealand groups are merged: the two groups that receive benefits (some and majority) are merged into one, and the households that doesn't receive benefits any with two or more adults form one group (merging the two and three or more categories). Section 7.3 in the appendix provides a table describing all the New Zealand employed categories simultaneously. The problem from section 4.8 remains, namely that households which receive benefits in New Zealand (regardless of whether they work or not) are compared to and treated as identical to any household in Scandinavia that does not have adults with paid work as their usual occupation (whether they receive benefits, or not). That so many New Zealand pensions are just above the poverty line is also a problem here. With these caveats in mind, the findings are still interesting.

As shown in table $5.7 \mathrm{~A}$, in one case, namely poverty level among benefit receiving households one of the counterfactual cases (Norwegian reduction rate) 


\begin{tabular}{|c|c|c|c|}
\hline 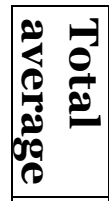 & 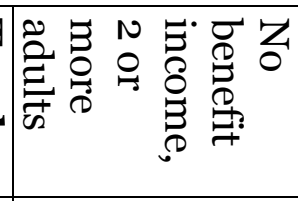 & 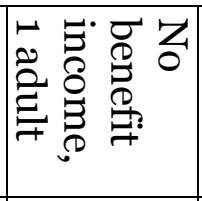 & 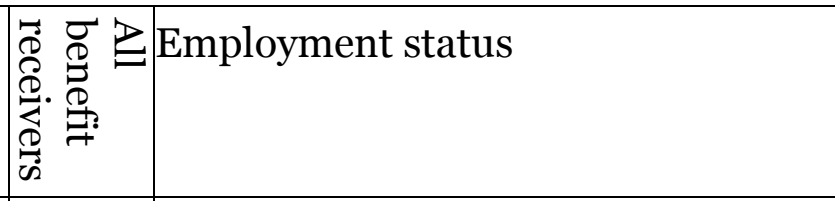 \\
\hline $\begin{array}{l}\stackrel{+}{\infty} \\
\infty \\
a \\
d 0\end{array}$ & $\begin{array}{l}0 \\
\text { it } \\
\text { ol }\end{array}$ & $\begin{array}{l}\because 1 \\
10 \\
10\end{array}$ & $\begin{array}{l}\stackrel{b}{\omega} \text { Norwegian actual disposable house- } \\
\dot{\sigma} \text { hold poverty rate } \\
\text { olo }\end{array}$ \\
\hline $\begin{array}{l}\stackrel{n}{6} \\
i \\
0 \\
010\end{array}$ & $\begin{array}{l}N \\
\sigma \\
\sigma o\end{array}$ & 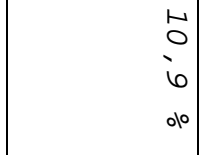 & $\begin{array}{l}\text { \& Counter-factual Norwegian poverty } \\
\text { ¿ rate, based on New Zealand's } \\
\text { olo market poverty rate }\end{array}$ \\
\hline $\begin{array}{l}\stackrel{\omega}{\omega} \\
\dot{0} \\
\text { do }\end{array}$ & $\begin{array}{l}\vdash \\
\text { N } \\
\text { ol }\end{array}$ & $\begin{array}{c}6 \\
v \\
10 \\
10\end{array}$ & \begin{tabular}{l|l} 
N & Swedish actual disposable household \\
i & poverty rate \\
olo &
\end{tabular} \\
\hline $\begin{array}{l}\stackrel{N}{N} \\
\text { is } \\
\text { do }\end{array}$ & 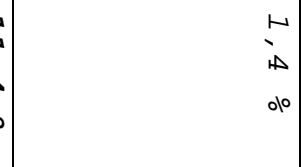 & $\begin{array}{l}V \\
6 \\
010\end{array}$ & 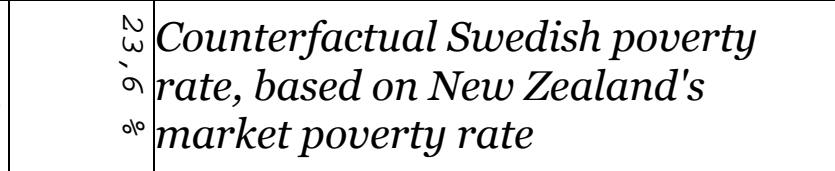 \\
\hline $\begin{array}{l}a \\
a \\
d 0\end{array}$ & $\begin{array}{l}0 \\
\text { iv } \\
\text { do }\end{array}$ & $\begin{array}{l}\overrightarrow{1} \\
\infty \\
10 \\
10\end{array}$ & $\begin{array}{l}\text { Norwegian actual disposable child } \\
\text { i poverty rate } \\
\text { of }\end{array}$ \\
\hline $\begin{array}{l}\infty \\
0 \\
0\end{array}$ & $\begin{array}{l}N \\
i \\
010\end{array}$ & $\begin{array}{c}\tilde{N} \\
0 \\
0 \\
0 \\
010\end{array}$ & $\begin{array}{l}\omega \\
{ }_{\infty} \text { Counter-factual Norwegian child } \\
\varsigma \text { poverty rate, based on New } \\
{ }^{\circ} \text { Zealand's market child poverty rate }\end{array}$ \\
\hline $\begin{array}{l}G \\
\sigma \\
d o\end{array}$ & $\begin{array}{l}\qquad \\
\omega \\
\text { do }\end{array}$ & $\begin{array}{l}\infty \\
\text { iv } \\
10\end{array}$ & 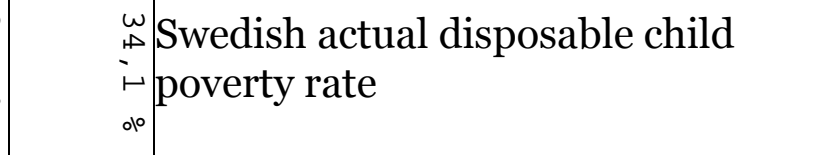 \\
\hline $\begin{array}{l}\overrightarrow{0} \\
0 \\
0\end{array}$ & $\begin{array}{l}5 \\
\vdots \\
10 \\
10\end{array}$ & $\begin{array}{l}\vec{N} \\
\mathrm{~N} \\
10\end{array}$ & 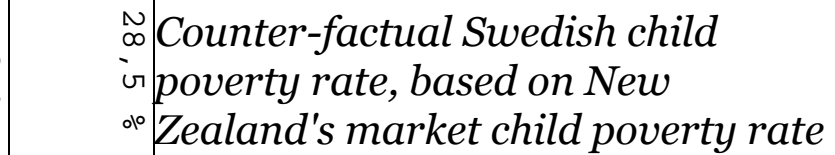 \\
\hline
\end{tabular}




\section{Answered and unanswered questions}

\subsection{Policy developments in New Zealand since 2000}

While this thesis relies on data from 2000, there have been several developments since then: policies has been changed, partly as a response to findings from the 2000 dataset suggesting widespread poverty in New Zealand, and new research based on more recent data has been published in part evaluate recent policy reforms. Among these is Perry (2004). He evaluates the effect on child poverty of the major policy shift in New Zealand since 2000, the introduction of the Working for Families package. This package seeks to combine the goals of "improving income adequacy [and] making work pay." (Centre for Social Research and Evaluation, 2007:1) as well as making sure that people receives the assistance they are entitled to. This combination is the application of the balance suggested in section 4.1 between reducing poverty and not reducing the incentive to work. Thus, many of the benefits are in the form of tax credits, and target those in work through tax credits or 'negative income tax', and increases in Family Support which benefits low income earners both within and outside the labour market. Perry (2004: 41) shows that this reduces child poverty significantly from $22 \%$ to $16 \%$ in one measure. Other studies show different findings, however: Fletcher and Dwyer (2008:65) finds that 22 percent of children were living in households with incomes below $60 \%$ of the median after housing costs are taken into account. StJohn and Wynd (2008) emphasis how none of the effort made through family tax credits benefits the children that needs it the most, namely those on in households that rely on benefits, and argues that a move towards universal child benefits is necessary (2008:135).

That the lower measure is still about ten percentage points higher than in Scandinavia means that it is still debatable whether the balance between ensuring income adequacy and making work pay is tilted sufficiently towards income adequacy. Studies such as StJohn and Wynd (2008) and Fletcher and Dwyer (2008) measures and highlight the multitude of aspects of deprivation experienced by poor children, and in a normative debate over this balance it is also worth noting that in absolute living standard poverty in New Zealand is more severe than in Scandinavia because overall living standards are lower. Given that New Zealanders already work 
relatively long hours and participation rates are high compared to most countries, it is questionable how effective incentives to work more will be in increasing productivity. It seems likely that even after the introduction of the working for families-package there is scope for reducing child poverty further, without risking dramatically lower productivity. 


\subsection{Answered questions}

Chapter two suggested that poverty can, for a variety of reasons, be inherited across generations, because experience of poverty as a child increases the risk of poverty later in life. This is an important explanation for policymakers' and researchers' interest in child poverty. This factor was also an important factor in this thesis.

Cross country studies of causes of poverty referred to in chapter 3 suggested that labour market relations are paramount in explaining differences in levels of poverty. Single-mother families and low female labour participation as well as low public social and health spending contributed to high child poverty rates. On this background this thesis focuses largely on demographics and labour relations as well as education in Scandinavia. The small number of country cases also allowed the inclusion ethnicity in a way that would not be meaningful in studies of a larger number of countries.

To study the prevalence of poverty and child poverty several methodological decisions were required. These were mostly done on a theoretical basis, but in some cases the availability of data forced the use of second best options. Among the decisions made were to apply a $60 \%$ of the median income poverty line, i.e. a relative measure of poverty, supplemented by a measure of poverty depth. Among the decision made by need rather than choice based on theory was the one to use to use the square root equivalence scale on data from Norway and Sweden, but the Jensen's equivalence scale on the New Zealand data.

Chapter three and four focused on market income poverty and disposable poverty, respectively. Each of the two chapters described the depth and incidence of poverty among households and children in various groups in the three countries. Much focus was given to various demographic groups, but ethnicity, education, and income source were also taken into account. The data were presented in frequency tables, and partly confirmed by regression analyses. Poverty data on each of these groups showed interesting and often complex dynamics, especially when market and disposable income data were contrasted.

In order to highlight the differences in policy and policy outcomes, chapter five summarised these findings in counterfactual portrayals of, among other things, what the incidence of poverty in New Zealand would have been if levels of 
poverty reduction (i.e. government intervention outcomes) had been implemented in New Zealand. This method provided a simplistic description of the importance of policy while taking market poverty and demographic differences into account.

Figure 6.1 Observed and counterfactual child poverty levels in New

\section{Zealand ${ }^{36}$}

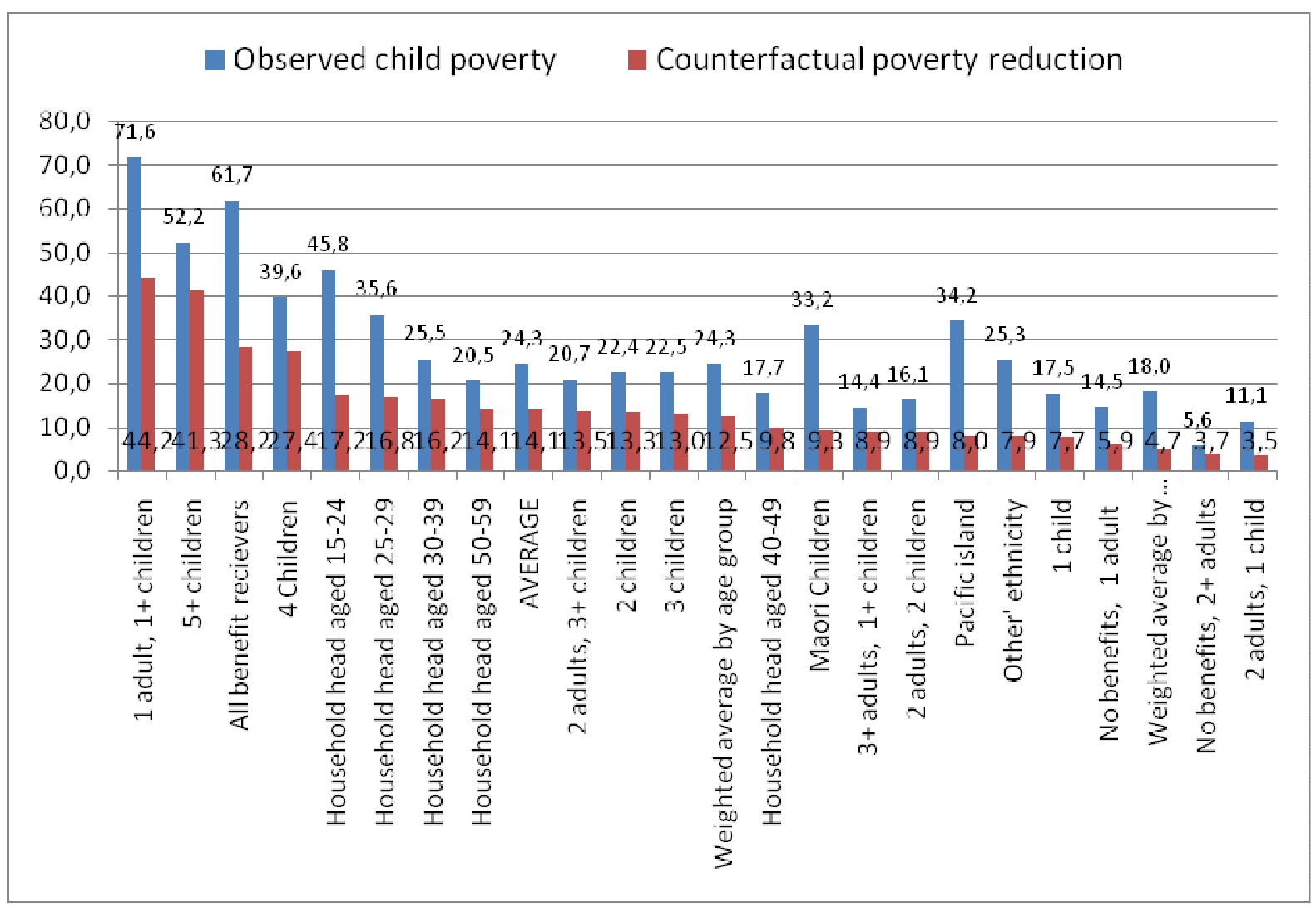

The light, blue columns in table 6.1 summarizes the observed child poverty rate in various groups in New Zealand, and the darker, red columns refers to the reduction in percentage point that would result if the poverty reduction rate were equal to the Scandinavian average. So, in households with one adult and one child the actual child poverty in New Zealand was 71.6\%, whereas if New Zealand had achieved the reduction in child poverty that was achieved in this group in Scandinavia (the average of Norway and Sweden), the poverty rate would have been 44.2 percentage points lower. The groups are ranked by the size of the reduction. It appears that children living with only one adult, adults that receive benefits, young household heads and minority ethnicity have relative minor advantage of Norwegian poverty reduction (large gap between blue and red column, since the blue column is

\footnotetext{
${ }^{36}$ All numbers are per cent. HHH refers to household head. In the weighted average groups the reduction specific to age, and in the weighted per child categories the units are weighted by number of households rather than per child. 'Other' ethnicity refers to those who does not identify as Māori, Pacific Islander, or 'European New Zealander' (see section 3.2). Ethnicity refers to that of the household head.
} 
bigger in all cases they are still better off) relative to households with large number of children or older adults and two or more adults. 


\subsection{Unanswered questions}

This final section suggests some topics that this thesis does not attempt to cover, and thus provide ideas for further research. First of all, the thesis has a limited scope in terms of time and space. Further analysis may wish to incorporate more countries and more recent data as they become available. Performing similar analyses of more countries would make a wider and more reliable picture, and could provide lessons about a wider spectre of policy solutions from different 'worlds of welfare' (Esping-Andersen, 1990). Extending the analysis in time would be particularly interesting because some of the New Zealand data applied here has already been analysed (e.g. Waldegrave, Stephens and King, 2003) and these findings may have had some impact on subsequent policy (Perry, 2004), notably with the "working for families"-package. More research is needed to fully assess how these changes in policy have changed the picture that this thesis presents based on the 2000 data. One way of doing this would be to run the same kind of counterfactual analysis as chapter 5 does with more recent data, and see how much of the differences in child poverty rates remain unexplained by differences in policy. Such a study may also wish to employ uniform equivalence scales.

A different direction could be taken from the same point of departure would be to consider what evidence exist that suggests that the changes in policy were a direct result of research findings that suggest that New Zealand policies were unsuccessful in reducing child poverty both compared to other countries and relative to the effect of taxes and transfers on household poverty levels. In a similar vein (in the sense that it points more towards political science than public policy) one could ask whether the seemingly lower priority given to eradicate child poverty in New Zealand than in Scandinavia was a result of different attitudes to equality of opportunity, and the role of the state in ensuring this. Starke (2008) provides a study of the political aspects of the radical welfare state retrenchment in New Zealand in the 1980 s and 1990s, and puts this in a comparative perspective.

The emphasis in the empirical section of this thesis is to describe those that were poor before government intervention in the three countries, the characteristics of those that governments succeeded in bringing out of poverty, and 
those who remained poor after government interventions through tax and transfers. The focus is not on explaining why some groups are poor or are more or less successful in using government assistance to relieve poverty. Nor is the focus on describing the policies that were more or less successful in bringing households and children out of poverty. These are, in other words, areas where there is left scope for further analyses.

Because of lack of equivalent data some of the analysis done for Sweden and Norway, were not performed with New Zealand data, notably on education, and the gender of household adult, as well as the analysis on assortative mating. It would also be interesting to see if the gender of children makes any difference on poverty. All of this leads to a somewhat incomplete analysis.

This thesis uses a 'snapshot' image to describe the poverty situation in the three countries. It does, in other words, not apply data that says anything about how long those that were poor remained poor for. This is the methodologically easiest approach and the only possible approach when access to longitudinal data is limited or even non-existent. However, it also gives a limited picture, especially because the focus on child poverty is chosen in part because experiencing poverty as a child can influence outcomes later in life, and thus equality of opportunity. Using 'snapshot' data is problematic in this context because the evidence that suggest that childhood poverty impact on later opportunities also show that prevailing poverty is a much more important risk factor than short spells. As data and resources become available research using longitudinal data is obviously needed. This kind of analysis is often also used to explore what sort of events that typically bring households and children into poverty (e.g. diPrete and McManus, 2000). Those analyses are important in explaining why some groups are poor, a topic already suggested in the previous paragraph.

Another limitation of the findings in this thesis and most studies doing similar analyses is that, as discussed in section 4.1, it does not measure accurately what impact changes in policy has on market income and labour market decisions at the household level. For policy-makers it is particularly interesting to know how much reductions in the incentives to work reduces the actual labour participation. To answer this one needs counterfactual analysis: what would be the outcome if policies were different and all other factors were constant. This thesis, for all its limitations, goes some way in answering one part of that question, and suggests that it is indeed 
possible for governments to come a long way in eradication child poverty. It does not, however, attempt to say anything about what the effect of the policies required to achieve this would have on labour participation, and thus ultimately economic growth. As already indicated the focus is on the impact of taxes and transfers on various groups, rather than on isolating which particular (tax and transfer) policies that lead to the different outcomes. As long as no conclusive evidence exists that measure the effect that policies that reduce child poverty has on economic growth controversy over this policy area will most certainly remain. 


\subsection{Conclusion}

This thesis has attempted to pull together many factors in one comparative study of child poverty. If nothing else it will have shown some of the depth and complexity income data as a way of studying living condition for children may involve.

Based on the theory and definition outlined in chapter two, the prevailing focus has been to measure the extent and depth of poverty measured in households and children in various groups, be they demographic, ethnic or educational. Measured along these axes market poverty was systematically compared with disposable income poverty, revealing a complex three-way relationship between poverty at the household level, demographic group variables (such as ethnicity, age, education and unemployment measured as market income), and effects of tax and transfer policies. Nearly all of these variables had an effect on poverty that was stronger when measured as child poverty rather than poverty at the household level. Furthermore, they appear to be cumulative. This has two major implications. Firstly, in societies where economic resources are scarce in some groups, children become major victims. This is important both because children have very limited opportunities to change their situation (even more so than adults), and because this limits their opportunities later in life. This, of course, is important both because of the direct suffering it causes, and because makes it impossible for society to give all its citizens and their children equal opportunities to succeed. Secondly, on a more positive note, it also shows that while policy is only one of several predictors of poverty, it has flow-on effects. In other words: a policy that reduces poverty in one vulnerable group will usually have a strong effect in bringing children out of poverty. The thesis' findings suggests that higher benefit levels, child assistance and more progressive taxes could have lowered child poverty and overall poverty substantially in New Zealand in year 2000.

Finally, to contrast the different situations in the 'antipodean' countries, a counterfactual thought experiment has been performed. This has shed some light on what the outcome would be if New Zealand had implemented Scandinavia's rate of poverty reduction in various groups, as well as what the result would be if Scandinavia had New Zealand's market poverty rates and demographic composition. The purpose behind this thought experiment was twofold: partly it was a way of 
presenting the detailed findings and comparisons of the chapters on market poverty and disposable poverty. It was also, however, theory driven: this particular approach was chosen with the aim of say something about the relative importance of government intervention, demographics and inequality created in the labour market in understanding differences in poverty rate between Norway and Sweden on the one hand, and New Zealand on the other. One such interesting finding is that it rules out the number of children in households as an important explanation of the higher child poverty in New Zealand: One finding was that if Norway and Sweden had New Zealand's distribution of children in households the increase in child poverty would be only marginal. This means that even though household type is highly important in explaining risk of poverty, it is of relatively minor importance when explaining the difference in poverty level between New Zealand and Scandinavia. Government policies could account for much more of the difference.

The findings made in the thesis are also relevant when exploring the relative merit of universal and targeted type benefit policies, despite the onedimensional perspective of the approach that was used here gives. It is still fair to say that the experiences of the targeted policies mostly employed in New Zealand do not appear to be superior in reducing child poverty when contrasted to the Scandinavian experience with more of the universal type benefits, even though they have some intuitive advantages at the theoretical level. The Scandinavian experiences also demonstrate that it is possible to combine mostly relying on universal benefits for income redistribution with relatively high levels of economic growth.

Generally the approach has shown that at least some of the child poverty in New Zealand in year 2000 was a result of deliberate or unconscious political choice. The positive flipside of this finding is that through policy reforms it is possible to reduce child poverty. 


\section{Appendix}

\subsection{The Revised Jensen Equivalence Scale}

\begin{tabular}{|l|l|l|l|l|l|l|l|}
\hline $\begin{array}{l}\text { Family } \\
\text { type }\end{array}$ & $\begin{array}{l}\text { No } \\
\text { children }\end{array}$ & $\begin{array}{l}1 \\
\text { child }\end{array}$ & $\begin{array}{l}2 \\
\text { children }\end{array}$ & $\begin{array}{l}3 \\
\text { children }\end{array}$ & $\begin{array}{l}4 \\
\text { children }\end{array}$ & $\begin{array}{l}5 \\
\text { children }\end{array}$ & $\begin{array}{l}6 \\
\text { children }\end{array}$ \\
\hline 1 adult & 0.65 & 0.91 & 1.14 & 1.34 & 1.52 & 1.69 & 1.85 \\
& $(1)$ & $(1.41)$ & $(1.73)$ & $(2)$ & $(2.24)$ & $(2.45)$ & $(2.65)$ \\
\hline 2 adults & 1 & 1.21 & 1.41 & 1.58 & 1.75 & 1.91 & 2.06 \\
& $(1.41)$ & $(1.73)$ & $(2)$ & $(2.24)$ & $(2.45)$ & $(2.65)$ & $(2.83)$ \\
\hline 3 adults & 1.29 & 1.47 & 1.65 & 1.81 & 1.96 & 2.11 & 2.25 \\
& $(1.73)$ & $(2)$ & $(2.24)$ & $(2.45)$ & $(2.65)$ & $(2.83)$ & $(3)$ \\
\hline 4 adults & 1.54 & 1.71 & 1.87 & 2.02 & 2.16 & 2.30 & 2.44 \\
& $(2)$ & $(2.24)$ & $(2.45)$ & $(2.65)$ & $(2.83)$ & $(3)$ & $(3.16)$ \\
\hline
\end{tabular}

The table shows that when using the Revised Jensen equivalence scale, a household of for example four adults and five children must have an income of 2.3 times the income of a household with two adults and no children to be considered to be equally well off. Square root equivalence factors are presented in parentheses. The two scales differ by a factor of absolute maximum 19.9 per cent: when comparing the poverty threshold for a household of one adult and one child in the Revised Jensen Equivalence scale to that of a household of four adults and 6 children in the Square root Equivalence scale, the two thresholds will differ by close to 20 per cent. However, for most other comparisons the discrepancy is much smaller. 


\subsection{Public sector social expenditure as a percentage of GDP}

\begin{tabular}{|l|l|l|l|}
\hline & New Zealand & Norway & Sweden \\
\hline Total & $19.1 \%$ & $22.2 \%$ & $28.7 \%$ \\
\hline Cash benefits & $11.3 \%$ & $11.1 \%$ & $14.4 \%$ \\
\hline In-kind benefits & $7.2 \%$ & $10.3 \%$ & $13.0 \%$ \\
\hline $\begin{array}{c}\text { Source: OECD Stats: Social Expenditure - Aggregated data from } \\
\text { http://stats.oecd.org/wbos }\end{array}$
\end{tabular}

Note that for some reason the total (not used in figure 4.2) in the original data are not equal to the sum of cash and in-kind benefits. 


\subsection{New Zealand source of income data and poverty; various categories}

\begin{tabular}{|c|c|c|c|c|c|c|c|c|}
\hline 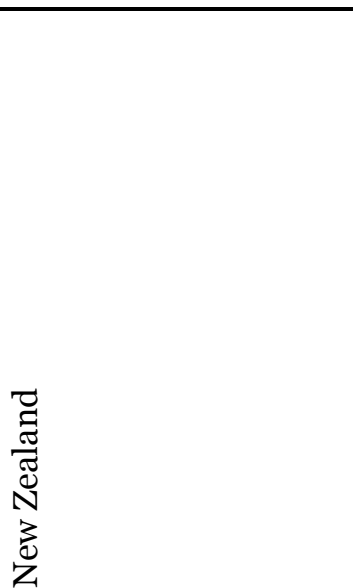 & 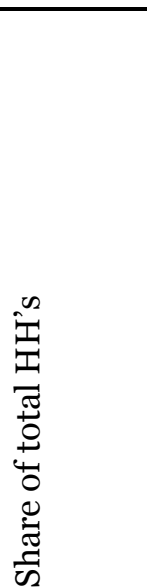 & 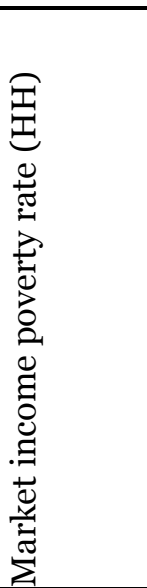 & 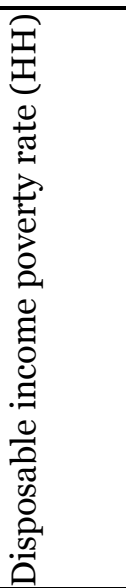 & 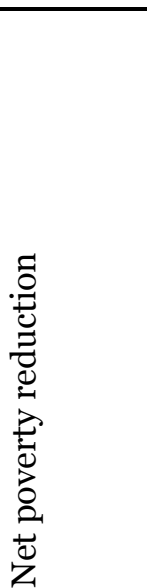 & 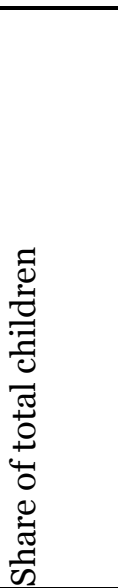 & 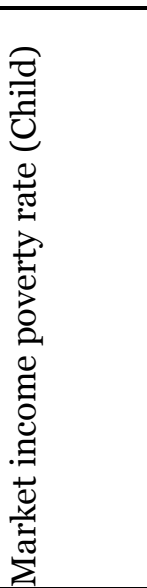 & 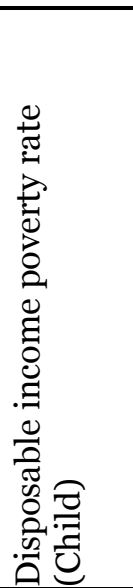 & 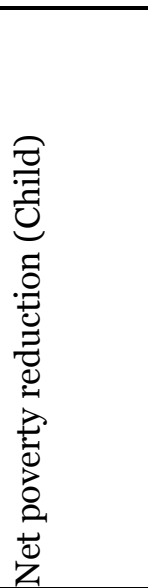 \\
\hline $\begin{array}{l}\text { Majority income from } \\
\text { benefits }\end{array}$ & $18,8 \%$ & $100,0 \%$ & $54,1 \%$ & $45,9 \%$ & $12,5 \%$ & $100,0 \%$ & $81,1 \%$ & $18,9 \%$ \\
\hline $\begin{array}{l}\text { Some income from } \\
\text { benefits }\end{array}$ & $15,1 \%$ & $57,6 \%$ & $20,8 \%$ & $63,9 \%$ & $12,1 \%$ & $63,1 \%$ & $41,6 \%$ & $34,0 \%$ \\
\hline $\begin{array}{l}1 \text { adult no benefit } \\
\text { income }\end{array}$ & $22,4 \%$ & $16,9 \%$ & $12,5 \%$ & $26,0 \%$ & $23,6 \%$ & $31,1 \%$ & $26,6 \%$ & $14,5 \%$ \\
\hline $\begin{array}{l}2 \text { adult no benefit } \\
\text { income }\end{array}$ & $32,3 \%$ & $3,7 \%$ & $4,8 \frac{0}{0}$ & $-29,7 \%$ & $42,9 \%$ & $5,6 \%$ & $6,5 \%$ & $-16,2 \%$ \\
\hline $\begin{array}{l}3+\text { adult no benefit } \\
\text { income }\end{array}$ & $11,4 \%$ & $2,1 \%$ & $2,9 \%$ & $-38,1 \%$ & $9,0 \%$ & $1,3 \%$ & $1,3 \%$ & $0,0 \%$ \\
\hline $\begin{array}{l}\text { Total in thousands } \\
\text { or average }\end{array}$ & $137,4 \%$ & $32,7 \%$ & $18,0 \%$ & $45,0 \%$ & 88600 & $29,9 \%$ & $24,3 \%$ & $18,7 \%$ \\
\hline All benefit receivers & $33,9 \%$ & $81,1 \%$ & $39,3 \%$ & $51,6 \%$ & $24,6 \%$ & $81,9 \%$ & $61,7 \%$ & $26,3 \%$ \\
\hline $\begin{array}{l}2 \text { or more adults w/o } \\
\text { benefit income\% }\end{array}$ & $43,7 \%$ & $3,3 \%$ & $4,3 \%$ & $-31,9 \%$ & $51,9 \%$ & $4,9 \%$ & $5,6 \%$ & $-13,4 \%$ \\
\hline
\end{tabular}

In section 5.4 the categories 'All benefit receivers' and ' 2 or more adults without benefit' replaces the majority and some income from benefits and the 2 and $3+$ adults without benefit categories respectively, that were used in section 4.8. The categories are merged in this part of the thesis to make the data as comparable as possible to the Scandinavian data. 


\section{Bibliography}

The data that this thesis is built around stems from two sources. The New Zealand data was kindly provided by Robert Stephens, New Zealand Poverty Measurement Project (NZPMP), and that information was derived from the data from the 2001 edition of the Household Economic Survey (HES). Stephens, Waldegrave and Frater (1995) provide the NZPMP methodology, Waldegrave, Stephens and King (2003) provide an analysis of the 2000/2001 data.

The data for Sweden and Norway was accessed from the Luxembourg Income Study (LIS) Database, http://www.lisproject.org/techdoc.htm (Norway and Sweden; 06/03/07-01/02/09).

Atkinson, Anthony Barnes. (1996) Incomes and the Welfare State: Essays on Britain and Europe. Cambridge: Cambridge University Press.

Ballantyne, Suzie, Simon Chapple, David C. Maré, and Jason Timmins. (2003) Movements into and out of Child Poverty in New Zealand: Results from the Linked Income Supplement. Wellington: Motu Economic and Public Policy Research.

Becker, G.S. (1991) A Treatise on the Family. Cambridge, MA.: Harvard University Press.

Bekkemellem, Karita. (2006) Seks Grunner Til A Advare Mot Frps Familiepolitikk. In Information from the Government and the Ministries, edited by Ministry_for_Children_and_Equality: government.no [the Norwegian Government].

Beller, Emily, and Michael Hout. (2006) Intergenerational Social Mobility: The United States in Comparative Perspective. The Future of Children 16:19-35.

Blaiklock, Alison J., Cynthia A. Kiro, Michael Belgrave, Will Low, Eileen Davenport, and Ian B. Hassall. (2002) When the Invisible Hand Rocks the Cradle: New Zeland Children in a Time of Change. In Innocenti Working Paper. Florence: UNICEF Innocenti Research Centre.

Blöndal, Sveinbjörn, Simon Field, and Nathalie Girouard. (2002) Investment in Human Capital through Post-Compulsory Education and Training: Selected Efficiency and Equity Aspects. In Economics Department Working Paper: OECD.

Boarini, Romina, and Hubert Strauss. (2007) The Private Internal Rates of Return to Tertiary Education: New Estimates for 21 Oecd Countries. In Economics Department Working Paper No. 591: OECD.

Borjas, George J., and Glenn T. Sueyoshi. (1997) Ethnicity and the Intergenerational Transmission of Welfare Dependency. In NBER Working Paper Series6175. Cambridge, MA: National Bureau of Economic Research.

Brady, David. (2004) Reconsidering the Divergence Betbween Elderly, Child, and Overall Poverty. Research on Aging 26:487-510.

Brooks-Gunn, Jeanne, and Greg J. Duncan. (1997) The Effects of Poverty on Children. The Future of Children 7:55-71.

Coleman, J. S. (1988) Social Capital in the Creation of Human Capital. American Journal of Sociology 94:95-120. 
Creedy, John, and Catherine Sleeman. (2004) Adult Equivalence Scales, Inequality and Poverty in New Zealand. In New Zealand Treasury Working Paper p. 32. Wellington: The Treasury.

d' Addio, Anna Christina. (2007) Intergenerational Transmission of Disadvantage: Mobility or Immobility across Generations? A Review of the Evidence for Oecd Countries. In OECD Social, Employment and Migration Working Papers, p. 113: OECD.

DiPrete, Thomas A., and Patricia A. McManus. (2000) Family Change, Employment Transitions and the Welfare State: Household Income Dynamics in the United States and Germany. American Sociological Review 65:343-70.

Esping-Andersen, Gösta. (2003) Against Social Inheritance. In Progressive Futures. London: Policy Network.

---. (1999) Social Foundations of Postindustrial Economies. New York: Oxford University Press.

- - . (1990) The Three Worlds of Welfare Capitalism. Princeton, N.J.: Princeton University Press.

Fletcher, Michael and Máire Dwyer. (2008) A Fair Go for All Children: Actions to address child poverty in New Zealand. Wellington: A report for the Children's Commissioner and Barnardos

Garfinkel, Irwin, Lee Rainwater, and Timothy M. Smeeding. (2006) A ReExamination of Welfare States and Inequality in Rich Nations: How in-Kind Transfers and Indirect Taxes Change the Story. Journal of Policy Analysis and Management 25:897-919.

Grossman, Michael. (2005) Education and Nonmarket Outcomes. In NBER Working Paper Series. Cambridge, MA: National Bureau of Economic Research.

Holzer, Harry, Diane Whitmore Schanzenbach, Greg J. Duncan, and Jens Ludwig. (2007) The Economic Costs of Poverty in the United States. Washington, D.C.: Center for American Progress.

Jencks, Christopher, and Laura Tach. (2005) Would Equal Opportunity Mean More Mobility? In KSG Faculty Research Working Paper. Cambridge, MA: Kennedy School of Government and Department of Sociology, Harvard University.

Jensen, John. (1988) Income Equivalences and the Estimation of Family Expenditures on Children. Wellington: Department of Social Welfare.

Jenson, Jane. (2004) Changing the Paradigm: Family Responsibility or Investing in Children. Canadian Journal of Sociology / Cahiers canadiens de sociologie 29:169-92.

Krishnan, Vasantha, John Jensen, and Suzie Ballantyne. (2002) New Zealand Living Standards 2000. Wellington: Centre for Social Research and Evaluation, Ministry of Social Development.

Machin, Stephen. (2006) Social Disadvantage and Education Experiences. In OECD Social, Employment and Migration Working Papers: Directorate for Employment, Labour and Social Affairs.

Madsen, Per Kongshøj. (2005) How Can It Possibly Fly? The Paradox of a Dynamic Labour Market in a Scandinavian Welfare State. In CARMA Research Paper. Aalborg: Centre for Labour Market Research (CARMA).

Maloney, Tim. (2004) Are the Outcomes of Young Adults Linked to the Family Income Experienced in Childhood? Social Policy Journal of New Zealand:5582. 
McLaughlin, Eithne, and John Baker. (2007) Equality, Social Justice and Social Welfare: A Road Map to the New Egalitarianisms. Social Policy \& Society 6:53-68.

Mogstad, Magne, Audun Langørgen, and Rolf Aaberge. (2007) Region Specific Versus Country Specific Poverty Lines in Analysis of Poverty. Journal of Economic Inequality 5:115-22.

Moller, Stephanie, Evelyne Huber, John D. Stephens, David Bradley, and Francois Nielsen. (2003) Determinants of Relative Poverty in Advanced Capitalist Democracies. American Sociological Review 68:22-51.

Maani, Sholeh A. (2004) Why Have Maori Relative Income Levels Deterioriated over Time. The Economic Record 80:101-24.

Perry, Bryan. (2002) The Mismatch between Income Measures and Direct Outcome Measures of Poverty. Social Policy Journal of New Zealand:101-27.

- - . (2004) Working for Families: The Impact on Child Poverty. Social Policy Journal of New Zealand:19-54.

Solon, Gary. (2002) Cross-Country Differences in Intergenerational Earnings Mobility. The Journal of Economic Perspectives 16:59-66.

- - . (1992) Intergenerational Income Mobility in the United States. The American Economic Review 82:393-408.

Starke, Peter. (2005) Resilient or Residual? From the Wage Earners' Welfare State to Market Conformity in New Zealand. In Collaborative Research Centre 597 "Transformations of the State". Bremen: University of Bremen.

Statistics New Zealand, _. (2007) Demographic Trends 2006. Wellington: Statistics New Zealand.

-_- . (2001) Household Economic Survey. Wellington: Statistics New Zealand.

Statistics Norway, (2007) Sami in Norway. In National overviews.

Stephens, Robert. (1999) Poverty, Family Finances and Social Security. In Redesigning the Welfare State in New Zealand, edited by Jonathan Boston, Paul Dalziel and Susan St John, pp. 238-59. Auckland: Oxford University Press.

Stephens, Robert, Charles Waldegrave, and Paul Frater. (1995) Measuring Poverty in New Zealand. Social Policy Journal of New Zealand.

St John, Susan and Donna Wynd. (2008) Left Behind: How Social and Income Inequalities damage New Zealand Children. Auckland: Child Poverty Action Group.

Stortinget. 2006. Nasjonal Strategi for A Utjevne Sosiale Helseforskjeller [National Strategy for Reduction of Social Health Inequalities]. Stortingsmelding

Tambs, Kristian, and Torbjørn Moum. (1992) No Large Convergence During Marriage for Health, Lifestyle, and Personality in a Large Sample of Norwegian Spouses. Journal of Marriage and the Family:957-71.

Waldegrave, Charles, Robert Stephens and Peter King (2003) "Assessing the Progress on Poverty Reduction”, Social Policy Journal of New Zealand, 23:197-222.

Whiteford, Peter, and Willem Adema. (2007) What Works Best in Reducing Child Poverty: A Benefit or Work Strategy. In OECD Social, Employment and Migration Working Papers: OECD.

Wilson, W. J. (1987) The Truly Disadvantaged: The Inner City, the Underclass, and Public Policy. Chicago, IL.: University of Chicago Press. 